Prepared in cooperation with the U.S. Army Corps of Engineers

\title{
Examination of Direct Discharge Measurement Data and Historic Daily Data for Selected Gages on the Middle Mississippi River, 1861-2008
}

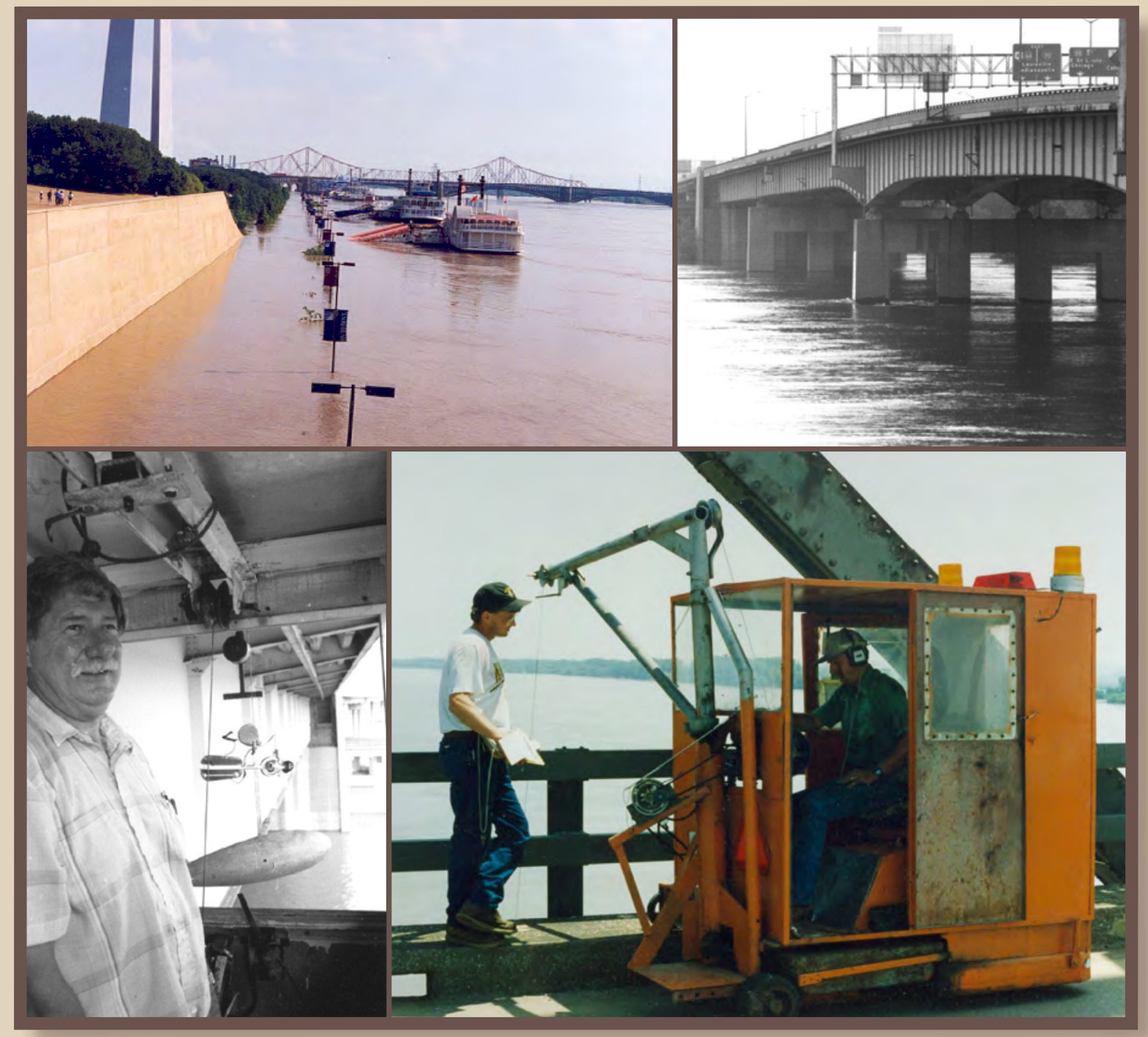

Scientific Investigations Report 2009-5232 


\begin{tabular}{|c|c|}
\hline A & B \\
\hline C & D \\
\hline
\end{tabular}

\section{COVER:}

Photographs from measurements made at streamgages on the Middle Mississippi River during the 1993 flood.

(A) Looking upstream towards the Eads Bridge from the monorail on the Poplar Street Bridge at St. Louis, Missouri.

(B) A discharge measurement being made from the monorail on the Poplar Street Bridge at St. Louis, Missouri.

(C) U.S. Geological Survey employee Leonard Huber making a discharge measurement from the monorail on the Poplar Street Bridge at St. Louis, Missouri.

(D) U.S. Geological Survey employee Robert Holmes, Jr., and Michael Kleeschulte making a discharge measurement from the Missouri Highway 51 Bridge at Chester, Illinois. 


\section{Examination of Direct Discharge Measurement Data and Historic Daily Data for Selected Gages on the Middle Mississippi River, 1861-2008}

By Richard J. Huizinga

Prepared in cooperation with the U.S. Army Corps of Engineers

Scientific Investigations Report 2009-5232 


\title{
U.S. Department of the Interior \\ KEN SALAZAR, Secretary
}

\author{
U.S. Geological Survey \\ Suzette M. Kimball, Acting Director
}

\section{U.S. Geological Survey, Reston, Virginia: 2009}

\begin{abstract}
For more information on the USGS — the Federal source for science about the Earth, its natural and living resources, natural hazards, and the environment, visit http://www.usgs.gov or call 1-888-ASK-USGS

For an overview of USGS information products, including maps, imagery, and publications, visit http://www.usgs.gov/pubprod

To order this and other USGS information products, visit http://store.usgs.gov
\end{abstract}

Any use of trade, product, or firm names is for descriptive purposes only and does not imply endorsement by the U.S. Government.

Although this report is in the public domain, permission must be secured from the individual copyright owners to reproduce any copyrighted materials contained within this report.

Suggested citation:

Huizinga, R.J., 2009, Examination of direct discharge measurement data and historic daily data for selected gages on the Middle Mississippi River, 1861-2008: U.S. Geological Survey Scientific Investigations Report 2009-5232, 60 p. 


\section{Contents}

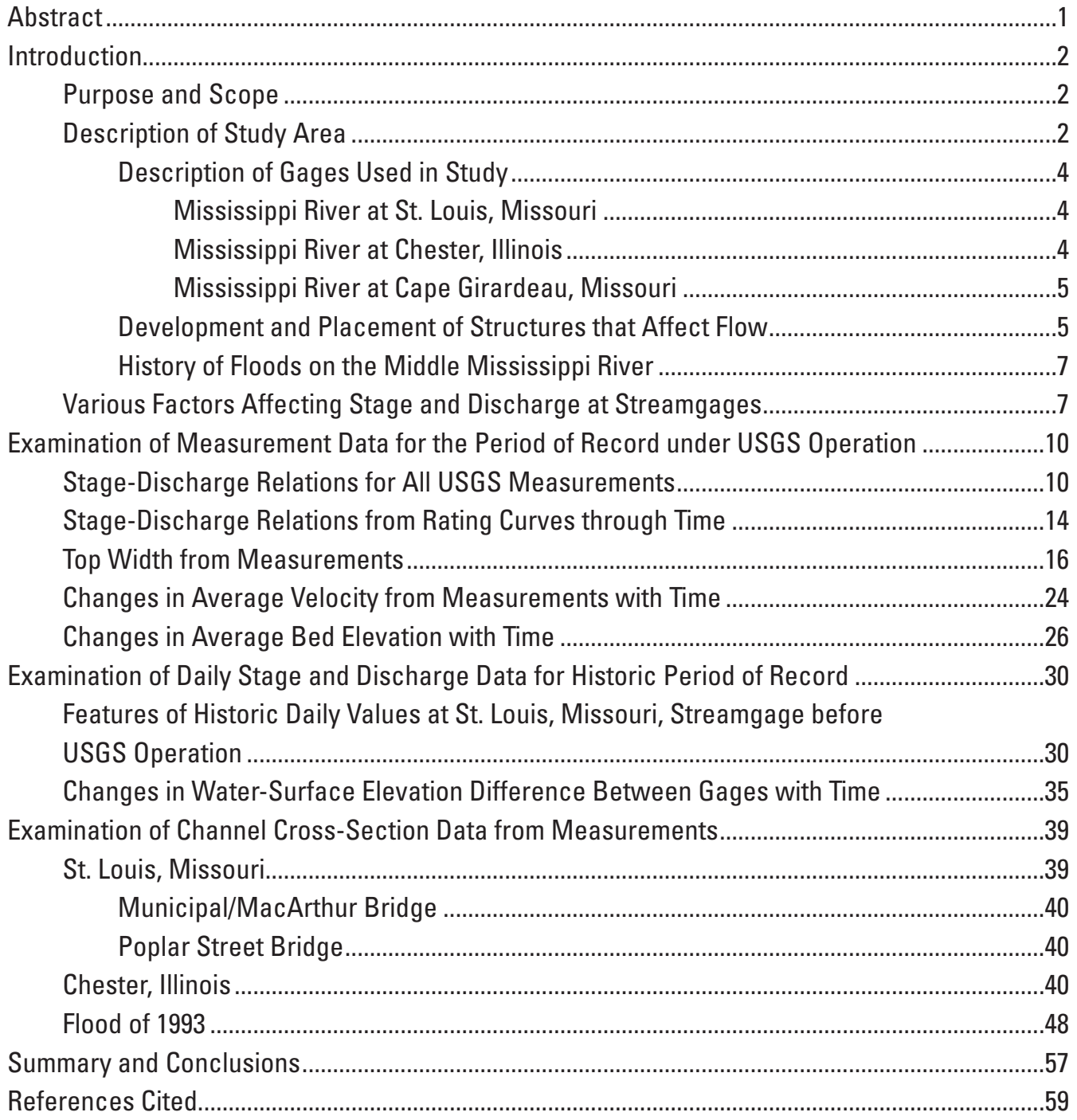

\section{Figures}

1. Map showing location of study area, streamgages and stage-only gages on the Middle Mississippi River

2-34. Graphs showing:

2. Distance upstream from the Ohio River and cumulative length of dikes built on the Middle Mississippi River since 1880 .

3. The current rating and the stage and discharge measurements upon which the rating is based for the streamgages at $(A)$ St. Louis, Missouri, and $(B)$ Chester, Illlinois, on the Middle Mississippi River. 
4. Stage and discharge from measurements made at the streamgages at $(A)$ St. Louis, Missouri, and $(B)$ Chester, Illinois, on the Middle Mississippi River.

5. Stage for a given discharge range with time from measurements made at the streamgages at $(A)$ St. Louis, Missouri, and $(B)$ Chester, Illinois, on the Middle Mississippi River

6. Ratings from the streamgages at (A) St. Louis, Missouri, and

(B) Chester, Illinois, on the Middle Mississippi River

7. Rated stage for a given discharge with time from ratings at the streamgages at $(A)$ St. Louis, Missouri, and (B) Chester, Illinois, on the Middle Mississippi River

8. Measured top width and discharge from measurements made at the streamgages at $(A)$ St. Louis, Missouri, and $(B)$ Chester, Illinois, on the Middle Mississippi River

9. Measured top width and discharge from measurements made at the streamgage at Chester, Illinois, on the Middle Mississippi River for various times during the period of record

10. Measured top width for a given discharge range with time from measurements made at the streamgages at $(A)$ St. Louis, Missouri, and $(B)$ Chester, Illinois, on the Middle Mississippi River.

11. Average velocity for a given discharge range with time from measurements made at the streamgages at $(A)$ St. Louis, Missouri, and $(B)$ Chester, Illinois, on the Middle Mississippi River.

12. Average bed elevation for a given discharge range with time from measurements made at the streamgages at $(A)$ St. Louis, Missouri, and $(B)$ Chester, Illinois, on the Middle Mississippi River.

13. Average bed elevation with time for all measurements less than bankfull made at the streamgages at St. Louis, Missouri, and Chester, Illinois, on the Middle Mississippi River

14. Stage and discharge from daily values for the 2008 water year (October 1, 2007 to September 30, 2008) at the streamgage at

St. Louis, Missouri, on the Middle Mississippi River

15. Stage and discharge from historic daily values from 1861 to 1927 at St. Louis, Missouri, on the Middle Mississippi River.

16. Stage and discharge from historic daily values from 1919 to 1933 at St. Louis, Missouri, on the Middle Mississippi River.

17. Original and adjusted daily values of stage and discharge from 1919 to 1927 at St. Louis, Missouri, on the Middle Mississippi River .35

18. Difference in daily water-surface elevation between the streamgages at St. Louis, Missouri, and Chester, Illinois, on the Middle Mississippi

River with time.

19. Difference in daily water-surface elevation between the gages at

St. Louis, Missouri, Chester, Illinois, and Cape Girardeau, Missouri, on the Middle Mississippi River with time. 
20. Cross sections from measurements made at the Municipal/MacArthur Bridge over the Mississippi River at St. Louis, Missouri, on the Middle Mississippi River, for discharges in the 100,000 cubic feet per second $+/-5$ percent range

21. Cross sections from measurements made at the Municipal/MacArthur Bridge over the Mississippi River at St. Louis, Missouri, on the Middle Mississippi River, for discharges in the 400,000 cubic feet per second +/- 2.5 percent range.

22. Cross sections from measurements made at the Municipal/MacArthur Bridge over the Mississippi River at St. Louis, Missouri, on the Middle Mississippi River, for discharges in the 600,000 cubic feet per second +/- 2 percent range

23. Cross sections from measurements made at the Poplar Street Bridge over the Mississippi River at St. Louis, Missouri, on the Middle Mississippi River, for discharges in the 100,000 cubic feet per second $+/-5$ percent range.

24. Cross sections from measurements made at the Poplar Street Bridge over the Mississippi River at St. Louis, Missouri, on the Middle Mississippi River, for discharges in the 400,000 cubic feet per second $+/-2.5$ percent range.

25. Cross sections from measurements made at the Poplar Street Bridge over the Mississippi River at St. Louis, Missouri, on the Middle Mississippi River, for discharges in the 600,000 cubic feet per second $+/-2$ percent range

26. Cross sections from measurements made at the Chester Bridge over the Mississippi River at Chester, Illinois, on the Middle Mississippi River, for discharges in the 100,000 cubic feet per second $+/-5$ percent range.

27. Cross sections from measurements made at the Chester Bridge over the Mississippi River at Chester, Illinois, on the Middle Mississippi River, for discharges in the 100,000 cubic feet per second $+/$ - 5 percent range from July 1966 through January 1996

28. Cross sections from measurements made at the Chester Bridge over the Mississippi River at Chester, Illinois, on the Middle Mississippi River, for discharges in the 400,000 cubic feet per second $+/-2.5$ percent range.

29. Cross sections from measurements made at the Chester Bridge over the Mississippi River at Chester, Illinois, on the Middle Mississippi River, for discharges in the 400,000 cubic feet per second $+/-2.5$ percent range from April 1969 through March 1997

30. Cross sections from measurements made at the Chester Bridge over the Mississippi River at Chester, Illinois, on the Middle Mississippi River, for discharges in the 600,000 cubic feet per second $+/-2$ percent range.

31. Cross sections from measurements made at the Chester Bridge over the Mississippi River at Chester, Illinois, on the Middle Mississippi River, for discharges in the 600,000 cubic feet per second $+/-2$ percent range from April 1973 through June 1995

32. Cross sections from measurements made during the 1993 flood the Poplar Street Bridge over the Mississippi River at St. Louis, Missouri, on the Middle Mississippi River 
33. Selected cross sections from measurements made during the 1993 flood at the Poplar Street Bridge over the Mississippi River at St. Louis, Missouri, on the Middle Mississippi River

34. Cross sections from measurements made during the 1993 flood the Chester Bridge over the Mississippi River at Chester, Illinois, on the Middle Mississippi River.

\section{Tables}

1. Annual peak values of discharge and gage height for selected streamgages on the Middle Mississippi River.

2. Discharge ranges used in the examination of discharge measurements at streamgages on the Middle Mississippi River

3. Gage height for a given discharge from ratings for the period of record during operation by the U.S. Geological Survey for the streamgage at St. Louis, Missouri (07010000)

4. Gage height for a given discharge from ratings for the period of record during operation by the U.S. Geological Survey for the streamgage at Chester, Illinois (07020500)

5. Summary of discharge measurements recorded by the Mississippi River Commission near St. Louis, Missouri, on the Middle Mississippi River from 1861 to 1923 (from Mississippi River Commission, 1925).

6. Mean annual difference in water-surface elevation between selected gages on the Middle Mississippi River 


\section{Conversion Factors}

\section{Inch/Pound to SI}

\begin{tabular}{lcl}
\hline Multiply & By & To obtain \\
\hline & Length & \\
\hline foot $(\mathrm{ft})$ & 0.3048 & meter $(\mathrm{m})$ \\
mile $(\mathrm{mi})$ & 1.609 & kilometer $(\mathrm{km})$ \\
\hline & Area & \\
\hline square mile $\left(\mathrm{mi}^{2}\right)$ & 2.590 & square kilometer $\left(\mathrm{km}^{2}\right)$ \\
\hline & Flow rate & \\
\hline foot per second $(\mathrm{ft} / \mathrm{s})$ & 0.3048 & meter per second $(\mathrm{m} / \mathrm{s})$ \\
cubic foot per second $\left(\mathrm{ft}^{3} / \mathrm{s}\right)$ & 0.02832 & cubic meter per second $\left(\mathrm{m}^{3} / \mathrm{s}\right)$ \\
\hline
\end{tabular}

Temperature in degrees Fahrenheit $\left({ }^{\circ} \mathrm{F}\right)$ may be converted to degrees Celsius $\left({ }^{\circ} \mathrm{C}\right)$ as follows:

${ }^{\circ} \mathrm{C}=\left({ }^{\circ} \mathrm{F}-32\right) / 1.8$

Vertical coordinate information is referenced to the National Geodetic Vertical Datum of 1929 (NGVD 29)

Horizontal coordinate information is referenced to the North American Datum of 1983 (NAD 83).

In this report, the words "left" and "right" generally refer to directions that would be reported by an observer facing downstream. 



\title{
Examination of Direct Discharge Measurement Data and Historic Daily Data for Selected Gages on the Middle Mississippi River, 1861-2008
}

\author{
By Richard J. Huizinga
}

\section{Abstract}

An examination of data from two continuous stage and discharge streamgages and one continuous stage-only gage on the Middle Mississippi River was made to determine stagedischarge relation changes through time and to investigate cause-and-effect mechanisms through evaluation of hydraulic geometry, channel elevation and water-surface elevation data. Data from discrete, direct measurements at the streamgages at St. Louis, Missouri, and Chester, Illinois, during the period of operation by the U.S. Geological Survey from 1933 to 2008 were examined for changes with time. Daily stage values from the streamgages at St. Louis (1861-2008) and Chester (18912008) and the stage-only gage at Cape Girardeau, Missouri (1896-2008), throughout the historic period of record also were examined for changes with time. Stage and discharge from measurements and stage-discharge relations at the streamgages at St. Louis and Chester indicate that stage for a given discharge has changed with time at both locations. An apparent increase in stage for a given discharge at increased flows (greater than flood stage) likely is caused by the raising of levees on the flood plains, and a decrease in stage for a given discharge at low flows (less than one-half flood stage) likely is caused by a combination of dikes in the channel that deepen the channel thalweg at the end of the dikes, and reduced sediment flux into the Middle Mississippi River. Since the 1960s at St. Louis, Missouri, the stage-discharge relations indicated no change or a decrease in stage for a given discharge for all discharges, whereas at Chester, Illinois, the stage-discharge relations indicate increasing stage for a given discharge above bankfull because of sediment infilling of the overflow channel.

Top width and average velocity from measurements at a given discharge for the streamgage at St. Louis, Missouri, were relatively constant through time, with the only substantial change in top width resulting from the change in measurement location from the Municipal/MacArthur Bridge to the Poplar Street Bridge in 1968. The average bed elevation appeared to be lowering with time at both measurement locations at St. Louis. Flow in the Horse Island Chute overflow channel for the streamgage at Chester, Illinois had an effect on top width and average velocity from measurements, and this effect changed with time as the inflow channel to Horse Island Chute filled with sediment. Top width from measurements at a given discharge was consistent through time at the Chester streamgage when adjusted to remove the part of the flow through Horse Island Chute. Average velocity from measurements at a given discharge appears to be increasing with time, possibly as a result of a series of dikes built or extended in the channel immediately upstream from the Chester streamgage; however, the average bed elevation for all discharges less than bankfull at the Chester streamgage fluctuate around an average value from 1948 to 2000, and the fluctuations appear to be related to the occurrence of moderate and large floods.

Daily stage and discharge values available for the streamgage at St. Louis, Missouri, from 1861 to 1932 display distinct, fixed relations that change slightly with time before operation by the U.S. Geological Survey, indicating daily discharge was obtained from the daily stage value during this timeframe. A sudden and substantial reduction of about 24 percent at the upper end of the ratings for discharge at a given stage occurred between 1932 and 1933 when the U.S. Geological Survey began operating the streamgage. This change likely is the result of the change to Price AA current meters from other, less-accurate methods used for discharge measurements before 1933. Based on modeling results for the Middle Mississippi River by the U.S. Army Corps of Engineers and the findings of this study, the accuracy of the historic record before 1933 is questionable, and needs to be examined further.

The difference in daily water-surface elevation between St. Louis, Missouri, Chester, Illinois, and Cape Girardeau, Missouri, also were examined from the 1890s onward. From the 1890s to the 1930s, the water-surface elevation differences between St. Louis and Chester and Cape Girardeau decreased, whereas the water-surface elevation difference between Chester and Cape Girardeau was nearly constant. The Kaskaskia cutoff in 1881 is the likely cause for the steady decrease between St. Louis and Chester, and the channel adjusted to the cutoff between the 1880s and 1930s. Other small but abrupt fluctuations in the water-surface elevation differences between the gages appear to be related to large flood events, or smaller flood events during extended periods of low flow. 
Cross sections extracted from measurements made at the streamgages at St. Louis, Missouri, and Chester, Illinois, were examined for changes with time. All of the cross sections displayed substantial variability through time, likely resulting from the effects of temperature, seasonal variations, and rising and falling stage. The cross sections for both measurement locations at the St. Louis streamgage and for the Chester streamgage indicated substantial variability at a given discharge range, but the variability appears to decrease after the early 1970s at the Chester streamgage for cross sections in the 100,000 cubic feet per second and 400,000 cubic feet per second discharge ranges, possibly because of work done on a dike field immediately upstream from the Chester streamgage. Cross sections from measurements made during the flood of 1993 also indicated the substantial variability of these sections with changing discharge in a single flood event. Substantial movement of bed sediments is apparent in the cross sections at the St. Louis streamgage during the 1993 flood, whereas the cross-section bed elevation steadily lowered until the 1993 flood peak at the Chester streamgage, and then rose to a level somewhat lower than before the flood.

\section{Introduction}

The collection of stage and discharge data for rivers and streams is vital to the well being of the various civilizations of the world. Water is vital to life, and knowledge about its distribution and movement on the globe is of critical concern to scientists and researchers. The amount of water flowing in a river or stream must be accurately determined to fully utilize its potential for good, and to adequately protect from its potential for harm.

The U.S. Army Corps of Engineers (USACE) has collected water-surface elevation and discharge data on rivers throughout the United States for more than a century as part of its mission, and beginning in the early 1930s, the U.S. Geological Survey (USGS) has worked cooperatively with the USACE to operate and maintain streamgages on the Mississippi and Missouri Rivers. River stage and discrete, direct discharge measurement data are available for these streamgages, as well as the various stage-discharge relations used to translate river stage to discharge. From the time the USGS began operating the streamgages until the early 2000s, discharge measurements were made using the Price AA current meter (Buchanan and Somers, 1969), generally from a bridge at or near the streamgage. During the 1990s, acoustic Doppler current profilers (ADCPs; Mueller and Wagner, 2009) began to be used to make discharge measurements, generally from a moving boat on a section of the river that is near the streamgage and contains minimal flow disturbances.

Structures within the main channel (hereinafter referred to as "in-stream structures") such as dikes and weirs have been constructed in major rivers to support navigation and later modified to support fish habitat. Structures on channel banks and flood plains such as levees and flood walls have been constructed to protect urban and agricultural areas within the flood plains. All of these structures have an effect on the riverine systems, and investigations of the effects of these structures have been ongoing (Shields, 1995; Smith and Winkley, 1996; Biedenharn and Watson, 1997; Pinter and others, 2001; Goldman and others, 2002; Pinter and Heine, 2004; Brauer and others, 2005; Jemberie and others, 2008). In-stream structures and structures on channel banks and flood plains are in abundance along the Middle Mississippi River (MMR), which is the part of the Mississippi River from the mouth of the Missouri River near St. Louis, Missouri, to the confluence of the Ohio River below Thebes, Illinois (U.S. Army Corps of Engineers, 2009b). Additional efforts such as riprap placement have been used to help stabilize the main channel of the MMR (U.S. Army Corps of Engineers, 2009b). The USGS, in cooperation with the USACE, conducted a study to address concerns about the effects of in-stream and other structures on flow in the MMR, and to investigate other potential cause-and-effect mechanisms affecting flow in the MMR.

\section{Purpose and Scope}

The purpose of this report is to document findings from the examination of data from selected gages on the MMR to determine stage-discharge relation changes through time and to investigate potential cause-and-effect mechanisms through examination of the hydraulic geometry and channel elevation. Historical stage and streamflow data collected at the streamgages on the Mississippi River at St. Louis, Missouri, (USGS streamgage station 07010000) from 1861 to 2008 and the Mississippi River at Chester, Illinois, (USGS streamgage station 07020500) from 1891 to 2008 are examined in this study. Historical stage data available at a third, stage-only gage on the Mississippi River at Cape Girardeau, Missouri, (USGS station 07020850) from 1896 to 2008 also are included in the analysis. Data from discrete, direct discharge measurements made at the streamgages at St. Louis and Chester for the period of record under USGS operation were examined. Daily stage and discharge data for the historic period of record at the St. Louis streamgage were examined, as were differences in daily stage at all three gages for the historic period of record.

\section{Description of Study Area}

The study area is the MMR, which is the part of the Mississippi River from the mouth of the Missouri River upstream from St. Louis, Missouri, to the confluence of the Ohio River on the southern tip of Illinois (fig. 1). 

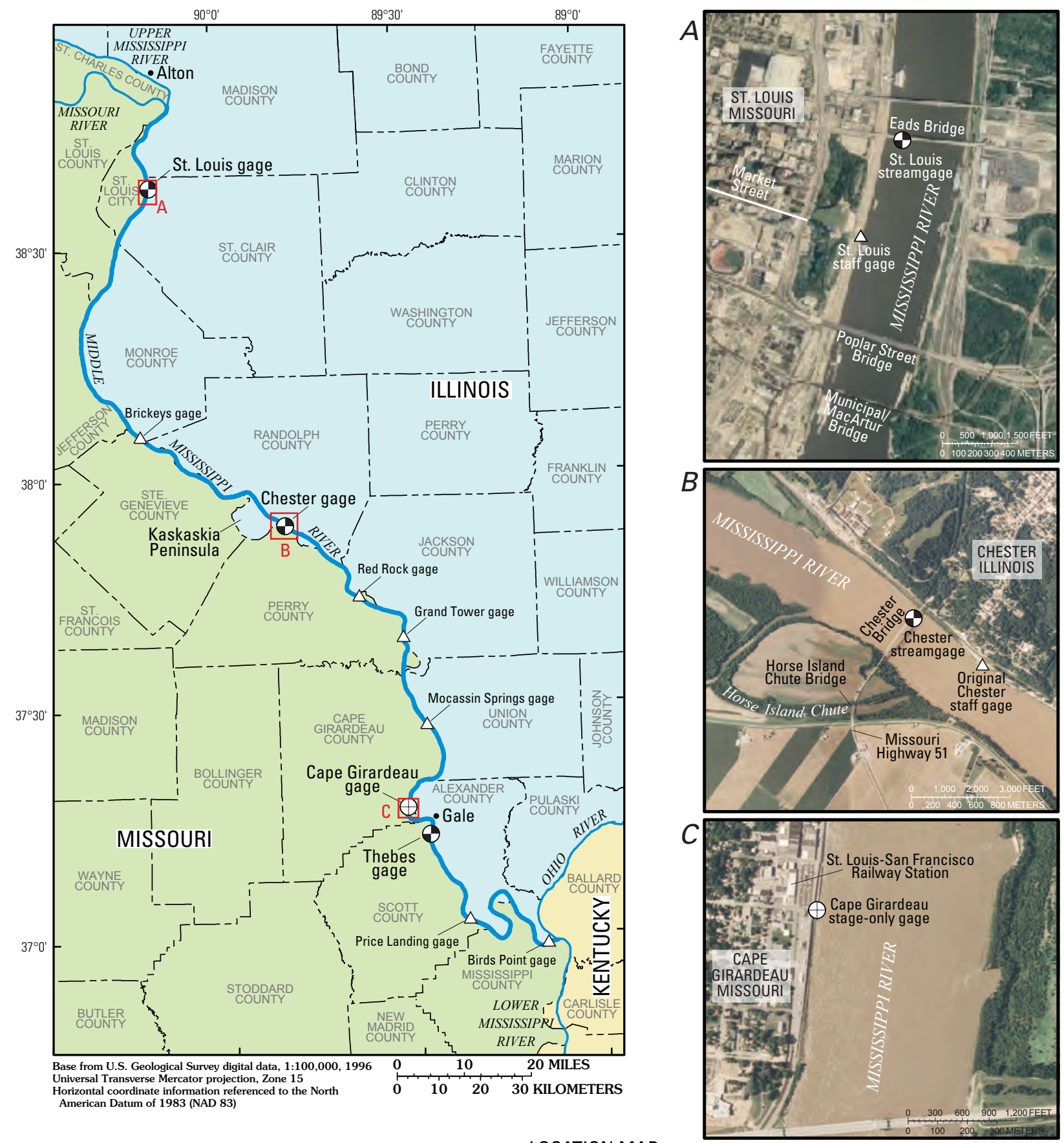

\section{EXPLANATION}

- Stage and discharge streamgage operated by the U.S. Geological Survey

$\oplus \quad$ Stage-only gage operated by the U.S. Geological Survey

$\triangle \quad$ Stage-only gage operated by the U.S. Army Corps of Engineers

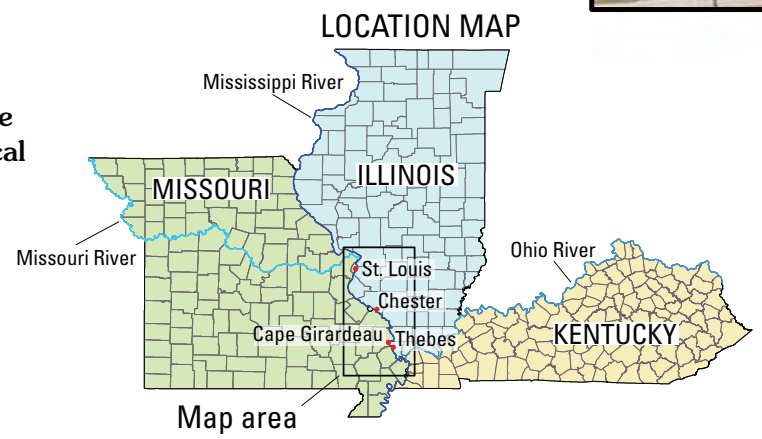

Figure 1. Location of study area, streamgages and stage-only gages on the Middle Mississippi River. 
Discharge and Historic Daily Data for Selected Gages on the Middle Mississippi River, 1861-2008

\section{Description of Gages Used in Study}

The USGS maintains three continuous stage and discharge streamgages on the MMR in cooperation with the USACE (fig. 1): at St. Louis, Missouri (USGS streamgage station 07010000), at Chester, Illinois (USGS streamgage station 07020500), and at Thebes, Illinois (USGS streamgage station 07022000). The USGS also maintains a continuous stage-only gage at Cape Girardeau, Missouri (USGS stage-only gage station 07020850) in cooperation with the USACE (fig.1), which is used as an auxiliary gage for a stage-fall-discharge relation (Rantz and others, 1982) at the base streamgage at Thebes. In addition, the USACE operates several stage-only gages on the MMR for navigation purposes. Such stations include gages at Brickeys, Missouri; Red Rock, Missouri; Grand Tower, Illinois; Mocassin Springs, Missouri; Price Landing, Missouri; and Birds Point, Missouri (fig. 1). For this study, only data from the gages at St. Louis, Chester, and Cape Girardeau were used; the stage-only gage at Cape Girardeau was used in deference to the streamgage at Thebes because it has a longer historic period of record.

Streamgages and continuous stage-only gages record river stage at defined time intervals (Buchanan and Somers, 1968; Carter and Davidian, 1968; Rantz and others, 1982). For a streamgage, these stage values are converted to a discharge value by means of a stage-discharge relation (hereinafter referred to as a "rating" or "rating curve," Carter and Davidian, 1968; Rantz and others, 1982). Ratings are developed for a streamgage using discharge values computed from direct measurements of channel velocity and area (hereinafter referred to as "discharge measurements") at or near the station throughout the range of stages observed at a site (Buchanan and Somers, 1969; Carter and Davidian, 1968; Rantz and others, 1982). Measurements are made periodically and routinely at each streamgage, and the stage of the river at each measurement is related to the measured discharge to develop the rating curve. Most of these routine measurements are in non-flood or high annual exceedance probability flow conditions, so special attempts are made to determine discharge during flood conditions to better define the rating at high stages.

When determining discharge with a Price AA current meter, the channel is divided into multiple sections of generally equal conveyance for which the depth, width, and average velocity are determined (Buchanan and Somers, 1969). The width and depth are multiplied together to obtain the incremental area of the section, which is further multiplied by the average velocity of the section to obtain the incremental discharge for the section. These incremental values of discharge, area, and width are used to compute the total discharge, cross-sectional area, and top width of the channel. Various other parameters (such as average depth) can be computed from the various incremental and total values obtained during a discharge measurement.

\section{Mississippi River at St. Louis, Missouri}

The streamgage at St. Louis, Missouri (USGS streamgage station 0701000 , hereinafter referred to as the "St. Louis gage," fig. 1) has been in existence since 1861 (U.S. Geological Survey, 2009a). The drainage area for the MMR upstream from this gage is approximately 697,000 square miles $\left(\mathrm{mi}^{2}\right)$. Daily river stage is read from a staff stage indicator, or "staff gage," on the right bank (looking downstream) of the river at the foot of Market Street in St. Louis at river mile 179.6. Flood stage at St. Louis is 30.0 feet ( $\mathrm{ft}$ ), referenced to the gage datum. Daily stage data were collected at the St. Louis gage by the Mississippi River Commission beginning in 1861 (U.S. Geological Survey, 2009a); the first discharge measurement was made in 1866 (Mississippi River Commission, 1925). In March 1933, the USGS began operating the gage as a continuous stage and discharge streamgage. A gage house was installed on the pier on the right side of the center main channel span of the Eads Bridge at river mile 180.0, approximately 0.4 mile (mi) upstream from the staff gage at the foot of Market Street (fig. 1A). The daily stage readings from the staff gage at Market Street archived by USACE are the daily stage values used in this study. The staff gage on Market Street and the streamgage on the Eads Bridge are at the same datum, and are sufficiently near each other that data from each are transferable to the other given the gentle slope of the channel.

From 1933 until the early 2000s, discharge measurements were made using a Price AA current meter suspended from a crane driven along a nearby bridge. From March 1933 until August 1968, measurements were made from the Municipal/ MacArthur Bridge $1.1 \mathrm{mi}$ downstream from the Eads Bridge (fig. 1A). From August 1968 until the early 2000s, discharge measurements were made using a Price AA current meter suspended from a monorail car on the Poplar Street Bridge 0.8 mi downstream from the Eads Bridge (fig. 1A). Measurements using ADCPs were made intermittently in 1993 and during 1998 to 2001, and were the predominant form of measurement (with occasional measurements made from the monorail with a Price AA current meter) in 2001 to 2003. From September 2003 to the present (2009), measurements at the St. Louis gage have been made exclusively using ADCPs.

\section{Mississippi River at Chester, Illinois}

The streamgage at Chester, Illinois (USGS streamgage station 07020500 , hereinafter referred to as the "Chester gage," fig. 1) has been in existence since 1873 (U.S. Geological Survey, 2009b). The drainage area for the MMR upstream from this gage is approximately $708,600 \mathrm{mi}^{2}$. Starting in 1891 , daily stage was read from a staff gage on the left bank (looking downstream) of the river approximately $0.4 \mathrm{mi}$ downstream from the present (2009) bridge over the Mississippi River on Missouri State Highway 51 (hereinafter referred to as the "Chester Bridge"; fig. 1B). Flood stage at Chester is $27.0 \mathrm{ft}$, referenced to gage datum. 
Daily stage data were collected at the Chester gage by the Mississippi River Commission beginning in 1891 (U.S. Geological Survey, 2009b); the first discharge measurement was made in 1898 (Mississippi River Commission, 1925). In July 1942, the USGS began operating the gage as a continuous stage and discharge streamgage. A gage house was installed on the left main channel span pier of the Chester Bridge at river mile 109.9 , approximately 0.4 mi upstream from the staff gage (fig. 1B). The gage datum of the gage house is the same as that of the original staff gage.

On the right flood plain near the Chester gage is an overflow channel called Horse Island Chute, which is spanned by a relief bridge called the Horse Island Chute Bridge (Huizinga and Rydlund, 2001: fig. 1B). Flow can occur in Horse Island Chute before the flood plain between the river and the chute is overtopped because the chute is connected to an old river channel upstream from the Chester gage.

From 1942 until the early 2000s, discharge measurements were made using a Price AA current meter suspended from a crane driven along the Chester Bridge and Horse Island Chute Bridge (fig. $1 B$ ), except for a series of boat measurements (made with a Price AA meter) between 1944 and 1946, when the main span of the Chester Bridge was being replaced after collapsing during a tornado. Measurements occasionally were made using ADCPs during 1993 and 1994, and were made predominantly using ADCPs (with occasional measurements made from the bridge crane using a Price AA current meter) between 1997 and 2003. From September 2003 to the present (2009), measurements at the Chester gage have been made exclusively using ADCPs.

\section{Mississippi River at Cape Girardeau, Missouri}

The stage-only gage at Cape Girardeau, Missouri (USGS station 07020850, hereinafter referred to as the "Cape Girardeau gage," fig. 1) has been in existence since 1896 (U.S. Army Corps of Engineers, 2009a). The drainage area for the MMR upstream from this gage is approximately $712,000 \mathrm{mi}^{2}$. Daily stage was read from a staff gage on the right bank of the river (looking downstream) just downstream from the St. Louis-San Francisco Railway Station at river mile 52.1 (fig. 1C). Flood stage at Cape Girardeau is $32.0 \mathrm{ft}$, gage datum.

The USGS began operating the Cape Girardeau gage in 1933 as an auxiliary gage for a stage-fall-discharge relation (Rantz and others, 1982) with the streamgage at Thebes, Illinois (USGS streamgage station 07022000 , hereinafter referred to as the "Thebes gage") $6 \mathrm{mi}$ downstream. Discharge records have never been collected at the Cape Girardeau gage, but discharge has been recorded by the USGS at the Thebes gage since 1933. In this study, the Cape Girardeau gage is used in deference to the Thebes gage because it has a longer historic period of record for stage data, extending back to 1896 at Cape Girardeau as opposed to 1932 at Thebes (U.S. Geological Survey, 2009c).

\section{Development and Placement of Structures that Affect Flow}

There are a variety of structures, such as wing dikes, levees, bendway weirs, and chevrons, built along and in channels that affect the hydraulics of flow. Wing dikes were first used near St. Louis, Missouri in 1837 (Brauer and others, 2005), and the first small levees were built in the 1880s (Gary Dyhouse, U.S. Army Corps of Engineers, written commun., 2009). Significant dike construction on the MMR did not start until the 1880 s, and levees tall enough to prevent moderate flooding were not in place until after World War I (Gary Dyhouse, U.S. Army Corps of Engineers, written commun., 2009). Bendway weirs were first used on the MMR in 1990 , and as of 2000, 150 had been built with a cumulative length of approximately 100,000 linear feet (Edward Brauer, U.S. Army Corps of Engineers, written commun., 2009). Chevrons were not present on the MMR until after 2000, and are not discussed any further in this report.

As their name implies, bendway weirs are used on the outside of river bends, and generally are low elevation stone sills constructed well below the water line, projecting from a bank into the flow at an angle that is upstream from perpendicular (Lagasse and others, 2001). On the MMR, the crest of each bendway weir is approximately $15 \mathrm{ft}$ below the Low Water Reference Plane (LWRP), the hydraulic reference plane that defines the low-water profile for the 97 percent flow duration line (U.S. Army Corps of Engineers, 2002), which is $-3.5 \mathrm{ft}$ gage datum at the St. Louis gage (Edward Brauer, U.S. Army Corps of Engineers, written commun., 2009). Bendway weirs work by utilizing weir hydraulics over the structure, subtly redirecting flow perpendicular to the axis of the weir, towards the channel centerline. According to Lagasse and others (2001), bendway weirs reduce near-bank velocities and reduce the concentration of currents on the outer bank of a bend. Although bendway weirs exist on the MMR, they have only a subtle effect on flow, and are submerged by more than $40 \mathrm{ft}$ of water at flood stage. Furthermore, assessment of the long-term effects of bendway weirs on the MMR from observed stage and discharge data is impossible given their relatively recent use.

Levees are raised embankments along and set back from the banks of a channel designed to contain flood flows within the channel and flood plains immediately adjacent to the channel, thereby providing flood protection to the area behind the levee. Often levees are joined to adjacent higher terrain or other levees to create cells that remain dry during flooding, except when the levee is overtopped or breached in some other way. Although levees are widely acknowledged to increase flood elevations at a particular section because of reduced flow area on flood plains (Dyhouse, 1995; Smith and Winkley, 1996), they only affect flows greater than bankfull conditions (the flow which causes the channel to be filled up to one or both banks, such that any greater flow would 
result in flood plain inundation), and only are part of the flood mitigation system employed by the USACE, which consists of levees, floodways, and flood control reservoirs. Until the mid-1930s, numerous small, low levees had been built on the MMR, mainly by local interests (Gary Dyhouse, U.S. Army Corps of Engineers, written commun., 2009). From the mid1940s to the mid-1960s, levees were built, strengthened, or raised as part of a comprehensive federal levee system on the MMR between Alton, Illinois, and Gale, Illinois, (hereinafter referred to as the "Alton-Gale levee system"). The Alton-Gale levee system was designed to provide protection up to the 2 percent annual exceedance probability (the probability of being exceeded in any given year; also referred to as the "50year" recurrence) flood in agricultural areas, and up to the 0.5 percent annual exceedance probability (200-year recurrence) flood in urban areas at the time they were constructed (Gary Dyhouse, U.S. Army Corps of Engineers, written commun., 2009).

Wing dikes (also called "spurs," hereinafter referred to simply as "dikes") are similar to bendway weirs in that they are stone sills projecting from a bank into the flow; however, dikes generally are visible above water level at low flow because they are built to an elevation approximately one-half way between the channel bed and bankfull. On the MMR, the crest of most dikes is approximately $18 \mathrm{ft}$ above the LWRP (Edward Brauer, U.S. Army Corps of Engineers, written commun., 2009), and are submerged by approximately $15 \mathrm{ft}$ of water at flood stage. Dikes work either by diverting flow around the structure, which often increases velocities and causes the channel to deepen off the end of the dike while creating an area of slack water downstream from the dike (Smith and Winkley, 1996), or by reducing flow velocities along the bank as flow passes through notches in the dike or through the dike structure (Lagasse and others, 2001). Between 1880 and 1900, there were 445 individual dikes built on the MMR, with a total cumulative length of more than 552,000 linear feet (fig. 2; Edward Brauer, U.S. Army Corps of Engineers, written commun., 2009). During the $20^{\text {th }}$ Century, there were approximately 800 individual dikes built or extended on the MMR, with a total cumulative length of nearly 475,000 linear feet (fig. 2; Edward Brauer, U.S. Army Corps of Engineers, written commun., 2009). Specific information about locations of dikes is not available before 1898, but approximately 20,000 linear feet of dikes were built or extended between 1898 and 1925, and nearly 290,000 linear feet of dikes were built or extended between 1925 and 1950 throughout the MMR. After a 10-year lull, approximately 87,000 linear feet were constructed between 1960 and 1970, primarily in the lower one-half of the MMR, followed by approximately 58,000 linear feet throughout the MMR from 1970 to 1984 . A final 19,000 linear feet were constructed in select locations from 1991 to 1997.

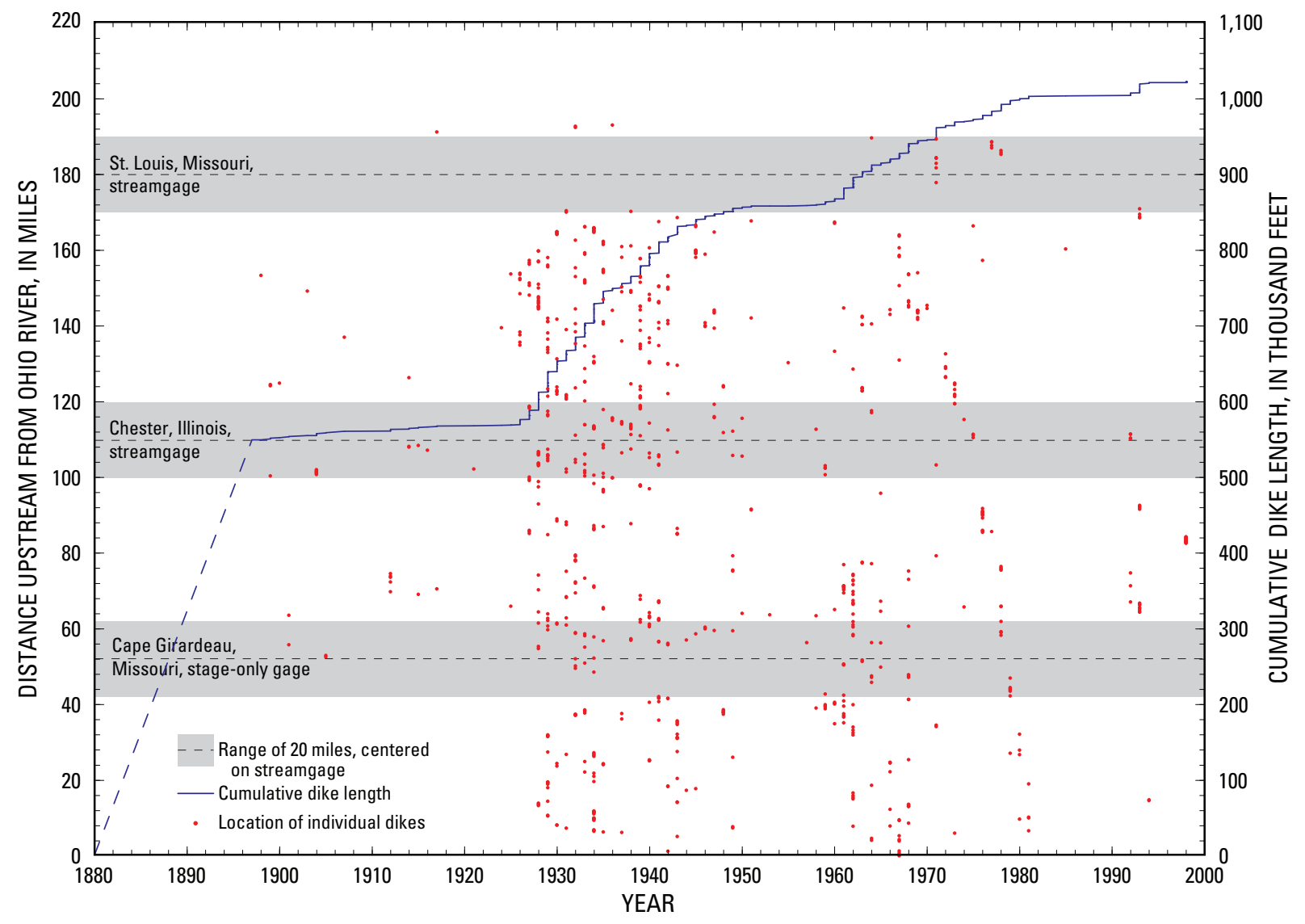

Figure 2. Distance upstream from the Ohio River and cumulative length of dikes built on the Middle Mississippi River since 1880. 


\section{History of Floods on the Middle Mississippi River}

Floods have occurred on the MMR throughout the period of the streamgages operation. The effects of moderate and large flood events must be considered when examining changes in streamgage records because floods can alter the channel geometry and, therefore, the stage-discharge relation at a streamgage.

Annual flood peaks from USGS peak flow files (U.S. Geological Survey, 2009d, 2009e) for the St. Louis and Chester gages are shown in table 1, verified and supplemented from various sources (Jarvis and others, 1936; Grover and Mansfield, 1938: Wells, 1955). The peak gage heights shown in table 1 for the period before the USGS began operating these streamgages are from records of the Mississippi River Commission, the USACE, and the U.S. Weather Bureau, and provide an accurate record of the stages of the Mississippi River at these two streamgages. The peak discharges shown in table 1 for the period before the USGS began operating these streamgages are from records of the Mississippi River Commission and the USACE, and represent a computed or estimated maximum daily discharge (Wells, 1955), generally determined from the daily stage data.

The St. Louis gage has annual peak discharges and gage heights for the past 147 years, plus a historic peak discharge estimated from peak flood elevations in 1844 (table 1). The Chester gage has annual peak discharges and gage heights for the past 83 years, plus a historic peak discharge estimated from peak flood elevations in 1844 (table 1). The actual discharge for the 1844 event is unknown, and was estimated for the St. Louis and the Chester gages by the USACE from the 1903 flood at the Chester and Thebes gages (Gary Dyhouse, U.S. Army Corps of Engineers, written commun., 2009), and later revised to the values shown in table 1 based on the results of physical and analytical model tests of this flood (Dyhouse, 1995; Dieckmann and Dyhouse, 1998) and further review by USACE (Melvin Baldus, U.S. Army Corps of Engineers, written commun., 1998). The 1844 historic peak discharge was exceeded by the peak discharge of 1993 at the St. Louis gage but not at the Chester gage, even though the peak gage height at the Chester gage or the 1993 flood exceeded the 1844 peak gage height by almost $10 \mathrm{ft}$ (table 1). The additional gage height at the Chester gage for the 1993 flood is because of several factors, including the levees that have been built on the flood plains (Gary Dyhouse, U.S. Army Corps of Engineers, written commun., 2009).

Based on the current (2009) published flood frequency tables from the USACE (Edward Brauer, U.S. Army Corps of Engineers, written commun., 2009), a discharge of 780,000 cubic feet per second $\left(\mathrm{ft}^{3} / \mathrm{s}\right)$ that occurs today has a 4 percent annual exceedance probability (25-year recurrence) at the St. Louis gage, and a discharge of $850,000 \mathrm{ft}^{3} / \mathrm{s}$ that occurs today has a 2 percent annual exceedance probability (50-year recurrence) at the St. Louis gage. As a result of changes in the Mississippi and Missouri River Basins with time (primarily the addition of main stem and tributary reservoirs and dams), the discharge associated with a given annual exceedance probability at a given streamgage has changed through the years (Gary Dyhouse, U.S. Army Corps of Engineers, written commun., 2009); nevertheless, the current (2009) discharges associated with the 4 and 2 percent annual exceedance probability floods represent generally what would be acknowledged to be moderately large floods throughout the history of the gage. Based on the data in table 1, there have been 16 years with a peak discharge value of $780,000 \mathrm{ft}^{3} / \mathrm{s}$ or greater at the St. Louis gage, seven of which have occurred since the USGS began operating the gage in 1933: 1943, 1944, 1947, 1951, 1973, 1993, and 1995. Nine of the floods shown in table 1 for the St. Louis gage have had a discharge of $850,000 \mathrm{ft}^{3} / \mathrm{s}$ or greater, only two of which have occurred since the USGS began operating the gage in 1933: 1973 and 1993.

At the Chester gage, there have been 10 years with a peak discharge value of $780,000 \mathrm{ft}^{3} / \mathrm{s}$ or greater, eight of which have occurred since the USGS began operating the gage in 1942 (table 1); 1943, 1944, 1947, 1951, 1973, 1983, 1993, and 1995. Although there are no discharge records for the Chester gage before 1928, it is likely that several of the larger historic floods highlighted for the St. Louis gage in table 1 also were large flood events at the Chester gage, given the peak gage heights at the Chester gage. Five of the floods shown in table 1 for the Chester gage have had a discharge of $880,000 \mathrm{ft}^{3} / \mathrm{s}$ or greater, three of which have occurred since the USGS began operating the gage in 1942 (table 1): 1947, 1973, and 1993.

\section{Various Factors Affecting Stage and Discharge at Streamgages}

In addition to the effects of in-channel and flood plain structures and floods described above, there are several natural factors affecting stage and discharge at streamgages, as well as sources of error in individual measurements. This is not intended to be a comprehensive discussion of the various factors that affect stage and discharge, but is included simply to highlight certain cause-and-effect relations between natural phenomena and river-flow characteristics, as well as how some of these are addressed in the stream discharge record.

Fenwick (1969) examined 897 discharge measurements from 18 streamgages on the Mississippi, Missouri, and Arkansas Rivers, and demonstrated with consistency that for a given river stage, a larger discharge was measured for cold water [50 degrees Fahrenheit $\left({ }^{\circ} \mathrm{F}\right)$ or less] than for warm water $\left(70{ }^{\circ} \mathrm{F}\right.$ or more). Specifically regarding the St. Louis gage, Fenwick determined that at a stage of $7 \mathrm{ft}$, the average discharge for cold water was $130,000 \mathrm{ft}^{3} / \mathrm{s}$, whereas the average discharge for warm water was $127,000 \mathrm{ft}^{3} / \mathrm{s}$, a difference of 2.4 percent. Similarly, at a stage of $25 \mathrm{ft}$, the average cold water discharge was $417,000 \mathrm{ft}^{3} / \mathrm{s}$, and the average warm water discharge was $374,000 \mathrm{ft}^{3} / \mathrm{s}$, a difference of 11.5 percent. The corollary of these temperature effects is that a lower stage will be indicated for cold water than for the same discharge of warm water. 


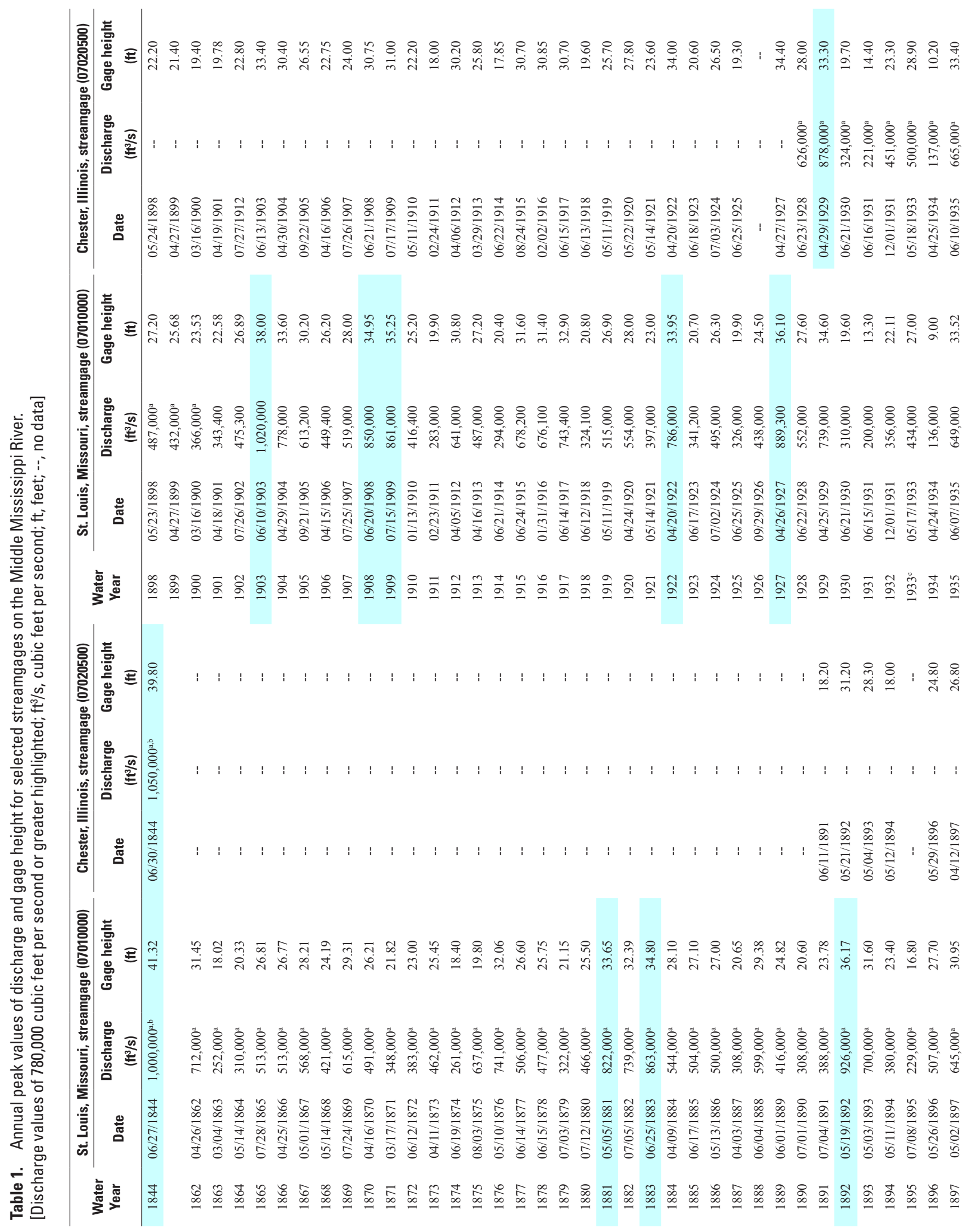




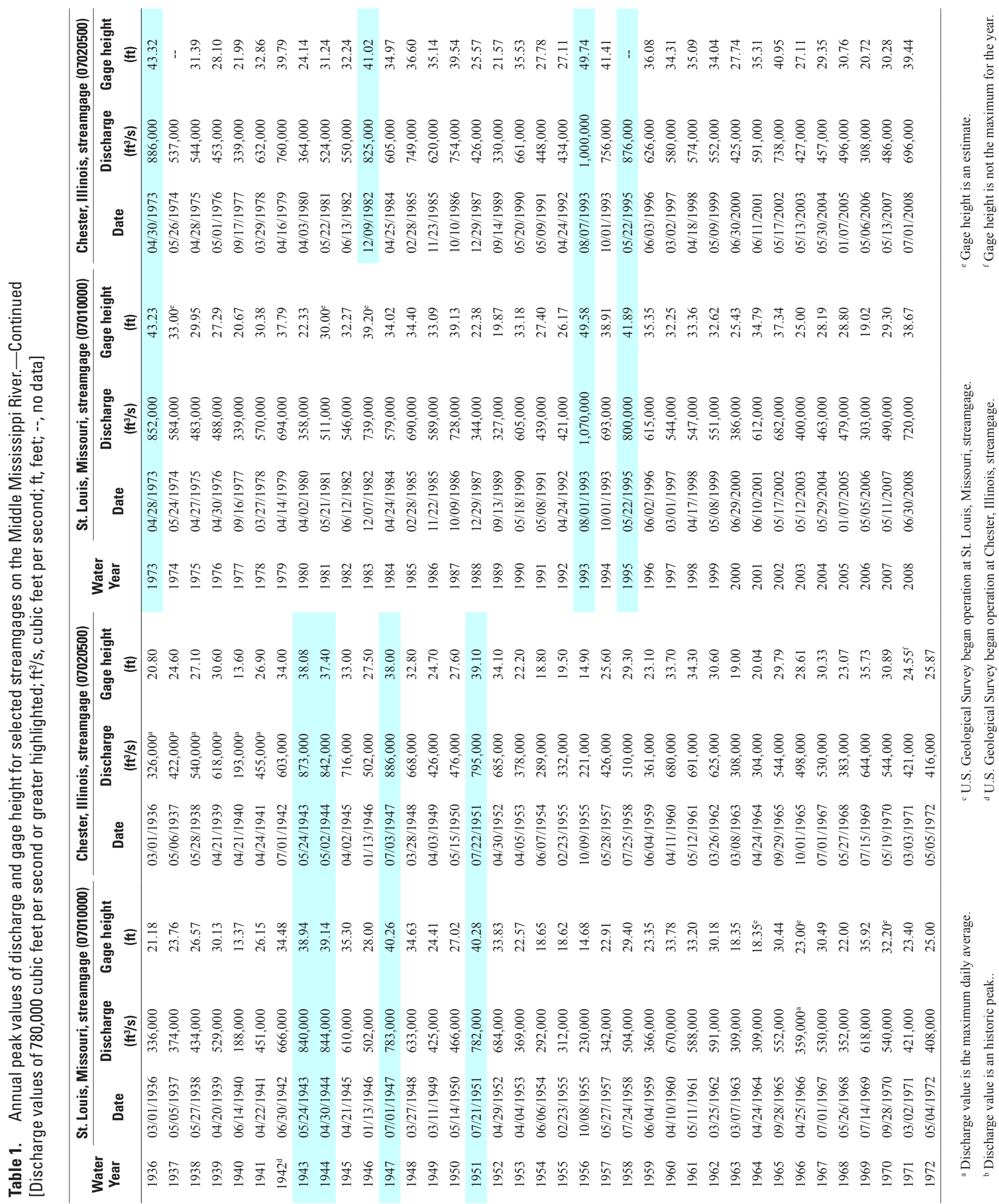


Simon, Li and Associates (1985) examined the seasonal shifts applied to rating curves at 17 streamgages on nine alluvial rivers, including the St. Louis and Chester gages. Specifically for these gages, they determined that there was a positive rating curve shift (indicating the observed stage for a given discharge is less than the stage predicted by the rating curve) during the winter, and a negative rating curve shift during the summer, which is consistent with the effects of temperature seen by Fenwick (1969). They further determined that the magnitude of the shift tended to be larger for larger discharges, again consistent with Fenwick. They include a thorough discussion of numerous studies describing the complex interactions of temperature and sediment transport, and their combined effects on channel bedforms and the resultant friction factor of an alluvial stream.

Another seasonal effect not specifically considered in the literature is seasonal variation in vegetation thickness. This effect is of primary concern during floods with flow on the flood plains, but can affect flow in the main channel after extended periods of low flow, which may allow vegetation to grow on banks and unsubmerged bars (Chow, 1959).

The timing of the measurement with regard to the flood hydrograph also can have an effect on the measured discharge. At sites with a shallow stream gradient, an increased discharge can be measured during a rising stage compared to a falling stage, creating a hysteresis loop during the flood hydrograph. During the rising limb of the hydrograph, the downstream water-surface elevations are lower than at the streamgage, allowing increased flow velocities, whereas during the falling limb of the hydrograph, the downstream water-surface elevations are greater than at the streamgage as the flood wave moves downstream, creating a backwater effect at the gage.

Furthermore, Sauer and Meyer (1992) describe several potential sources of error in individual measurements made with a vertical axis, cup-type current meter like the Price AA. Such error sources include errors in cross-sectional area, errors in mean stream velocity, errors associated with computation methods, and errors caused by changes in stage, boundary effects, ice, obstructions, wind, incorrect equipment or techniques, carelessness, and other factors. Although Sauer and Meyer provide a procedure for quantitatively combining these individual errors into an overall discharge measurement error, the more qualitative method of determining measurement accuracy in use before their work has continued to be used. The qualitative method is based on an assessment of several factors (rooted in the error sources described above), such as cross-section uniformity, velocity uniformity, stream bed conditions, and other factors that might affect the accuracy of the measurement. The discharge measurement is given an accuracy rating based on how close the measured discharge is to what is thought to be the actual "true" discharge: an "excellent" measurement is one where the measured discharge is within 2 percent of the "true" discharge; a "good" measurement is within 5 percent; a "fair" measurement is within 8 percent; and a "poor" measurement exceeds 8 percent difference (Rantz and others, 1982). Although qualitative in nature,
Sauer and Meyer (1992) state that error studies have shown that the qualitative method was a reasonable rating system, and this has been further confirmed by work currently (2009) being done by the USGS (Robert Holmes, Jr., U.S. Geological Survey, oral commun., 2009).

Temperature effects, other seasonal variations, position on the flood hydrograph, and measurement errors all cause variations in measurements of stage and discharge, and it is important to be aware of them in any analysis of stage and discharge. Caution must be exercised when comparing two identical discharges with differing stages, or two identical stages with differing discharges, to draw specific conclusions as to what has caused the change. All potential causes for differences must be considered, as well as whether or not the differences are "real" or a function of inherent inaccuracies or error in the measurements.

\section{Examination of Measurement Data for the Period of Record under USGS Operation}

Before the USGS began operating the streamgages on the MMR, discharge measurements were made using various kinds of wooden floats and meters other than the Price AA current meter. Since the USGS began operating the streamgages, discharge measurements have been made using Price AA current meters or ADCPs. Comparison measurements made between the USACE and USGS in the mid-1940s (Gary Dyhouse, U.S. Army Corps of Engineers, written commun., 2009) and by Stevens (1979) indicated that discharge measurements made by the USACE using floats and other meters consistently overestimated flood flows compared to measurements made by the USGS using the Price AA current meter, whereas Oberg and Mueller (2007) indicate that discharge measurements made with Price AA current meters and ADCPs produce comparable results; therefore, this study focuses on discharge measurements made at the streamgages while they were being operated and maintained by the USGS. For parts of this analysis, data from measurements were grouped by discharge, using the ranges shown in table 2 to provide sets of measurements near the desired discharge.

\section{Stage-Discharge Relations for All USGS Measurements}

As described in the "Description of Gages Used in Study" section above, streamgages do not measure discharge directly; rather, discharge is related to measured stage by means of a stage-discharge relation. This relation is built from multiple, periodic measurements of stage and discharge made at the station. The current (2009) rating is based on measurements made in the recent past at each station (fig. 3), 
Table 2. Discharge ranges used in the examination of discharge measurements at streamgages on the Middle Mississippi River.

$\left[\mathrm{ft}^{3} / \mathrm{s}\right.$, cubic feet per second]

\begin{tabular}{|c|c|c|c|c|c|}
\hline \multirow[b]{2}{*}{$\begin{array}{c}\text { Discharge } \\
\left(\mathrm{ft}^{3} / \mathrm{s}\right)\end{array}$} & \multirow[b]{2}{*}{$\begin{array}{c}\text { Range } \\
\text { (percent) }\end{array}$} & \multicolumn{2}{|c|}{ Discharge range } & \multicolumn{2}{|c|}{ Number of measurements } \\
\hline & & $\begin{array}{l}\text { Lower value } \\
\qquad\left(\mathrm{ft}^{3} / \mathrm{s}\right)\end{array}$ & $\begin{array}{c}\text { Upper value } \\
\left(\mathrm{ft}^{3} / \mathbf{s}\right)\end{array}$ & $\begin{array}{c}\text { St. Louis } \\
\text { streamgage } \\
07010000\end{array}$ & $\begin{array}{c}\text { Chester } \\
\text { streamgage } \\
07020500\end{array}$ \\
\hline 40,000 & 5.0 & 38,001 & 41,999 & 11 & 2 \\
\hline 50,000 & 5.0 & 47,501 & 52,499 & 55 & 16 \\
\hline 60,000 & 5.0 & 57,001 & 62,999 & 68 & 32 \\
\hline 70,000 & 5.0 & 66,501 & 73,499 & 153 & 91 \\
\hline 80,000 & 5.0 & 76,001 & 83,999 & 128 & 99 \\
\hline 90,000 & 5.0 & 85,501 & 94,499 & 166 & 118 \\
\hline 100,000 & 5.0 & 95,001 & 104,999 & 138 & 117 \\
\hline 150,000 & 5.0 & 145,001 & 154,999 & 100 & 70 \\
\hline 200,000 & 2.5 & 195,001 & 204,999 & 59 & 56 \\
\hline 300,000 & 2.5 & 292,501 & 307,499 & 57 & 42 \\
\hline 400,000 & 2.5 & 390,001 & 409,999 & 41 & 25 \\
\hline 500,000 & 2.0 & 490,001 & 509,999 & 25 & 17 \\
\hline 600,000 & 2.0 & 588,001 & 611,999 & 14 & 14 \\
\hline 700,000 & 1.5 & 689,501 & 710,499 & 11 & 13 \\
\hline 800,000 & 1.0 & 792,001 & 807,999 & 4 & 4 \\
\hline 850,000 & 1.0 & 841,501 & 858,499 & 1 & 2 \\
\hline 900,000 & 1.0 & 891,001 & 908,999 & 3 & 1 \\
\hline
\end{tabular}

and reflects the controlling flow conditions of the channel and flood plains at the streamgage. As of December 31, 2008, there have been 3,356 discharge measurements at the St. Louis gage since 1933, and 2,594 measurements at the Chester gage since 1942. Plots of these measurements, as well as the current (2009) stage-discharge relation at each streamgage, are shown in figure 4.

Few of the measurements made at the streamgages plot on the current (2009) rating, other than the measurements upon which the rating is based (fig. 4). Through the history of each streamgage, there is a broad range of discharges that have been measured for a given stage; similarly, there is a broad range of stages that have been measured for a given discharge, particularly for higher stages or flows. For example, for $500,000 \mathrm{ft}^{3} / \mathrm{s}$ at the St. Louis gage (fig. $4 A$ ), the measured stages range from approximately 26.5 to $32.0 \mathrm{ft}$, and at the Chester gage (fig. 4B), 500,000 ft $3 / \mathrm{s}$ has been measured at stages ranging from approximately 27.5 to $33.0 \mathrm{ft}$. The range of stages for a given measured discharge becomes larger with increasing discharge (fig. 4).

The current (2009) rating generally is below the historic measurements for $200,000 \mathrm{ft}^{3} / \mathrm{s}$ or less at the St. Louis gage, and for $150,000 \mathrm{ft}^{3} / \mathrm{s}$ or less at the Chester gage; or, stated another way, the stage for a given measured discharge currently (2009) is less than it historically has been for discharges less than $200,000 \mathrm{ft}^{3} / \mathrm{s}$ at the St. Louis gage or $150,000 \mathrm{ft}^{3} / \mathrm{s}$ at the Chester gage. The current (2009) rating at the St. Louis gage generally is at the center of the range of measurements between $400,000 \mathrm{ft}^{3} / \mathrm{s}$ and $850,000 \mathrm{ft}^{3} / \mathrm{s}$, or the stage for a given measured discharge currently (2009) will be near the middle of the range for which it has been measured historically at the St. Louis gage for discharges between 400,000 $\mathrm{ft}^{3} / \mathrm{s}$ and $850,000 \mathrm{ft}^{3} / \mathrm{s}$. At the Chester gage, the current (2009) rating is at the upper edge of measured discharges between $400,000 \mathrm{ft}^{3} / \mathrm{s}$ and $850,000 \mathrm{ft}^{3} / \mathrm{s}$, or the stage for a given measured discharge currently (2009) will be near the top of the range for which it has been measured historically at the Chester gage for discharges between $400,000 \mathrm{ft}^{3} / \mathrm{s}$ and $850,000 \mathrm{ft}^{3} / \mathrm{s}$. The current (2009) rating at the St. Louis gage is at the bottom of the range of discharge measurements greater than $850,000 \mathrm{ft}^{3} / \mathrm{s}$, or the stage for a given measured discharge greater than $850,000 \mathrm{ft}^{3} / \mathrm{s}$ currently (2009) will be at the bottom of the range for which it has been historically measured at the St. Louis gage. At the Chester gage, the current (2009) 

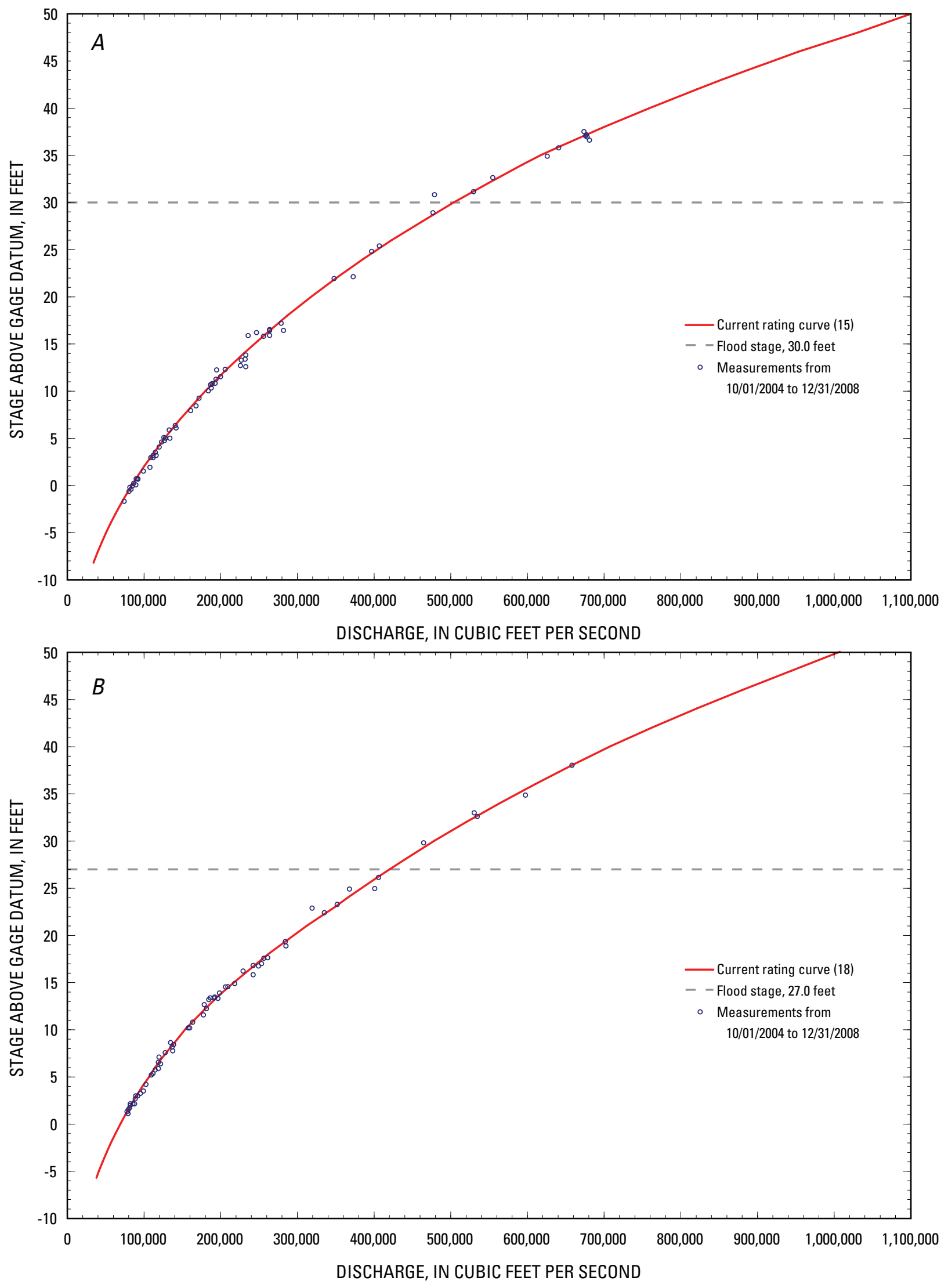

Figure 3. The current (2009) rating and the stage and discharge measurements upon which the rating is based for the streamaaqes at $(A)$ St. Louis. Missouri, and $(B)$ Chester. Illinois on the Middle Mississippi River. 

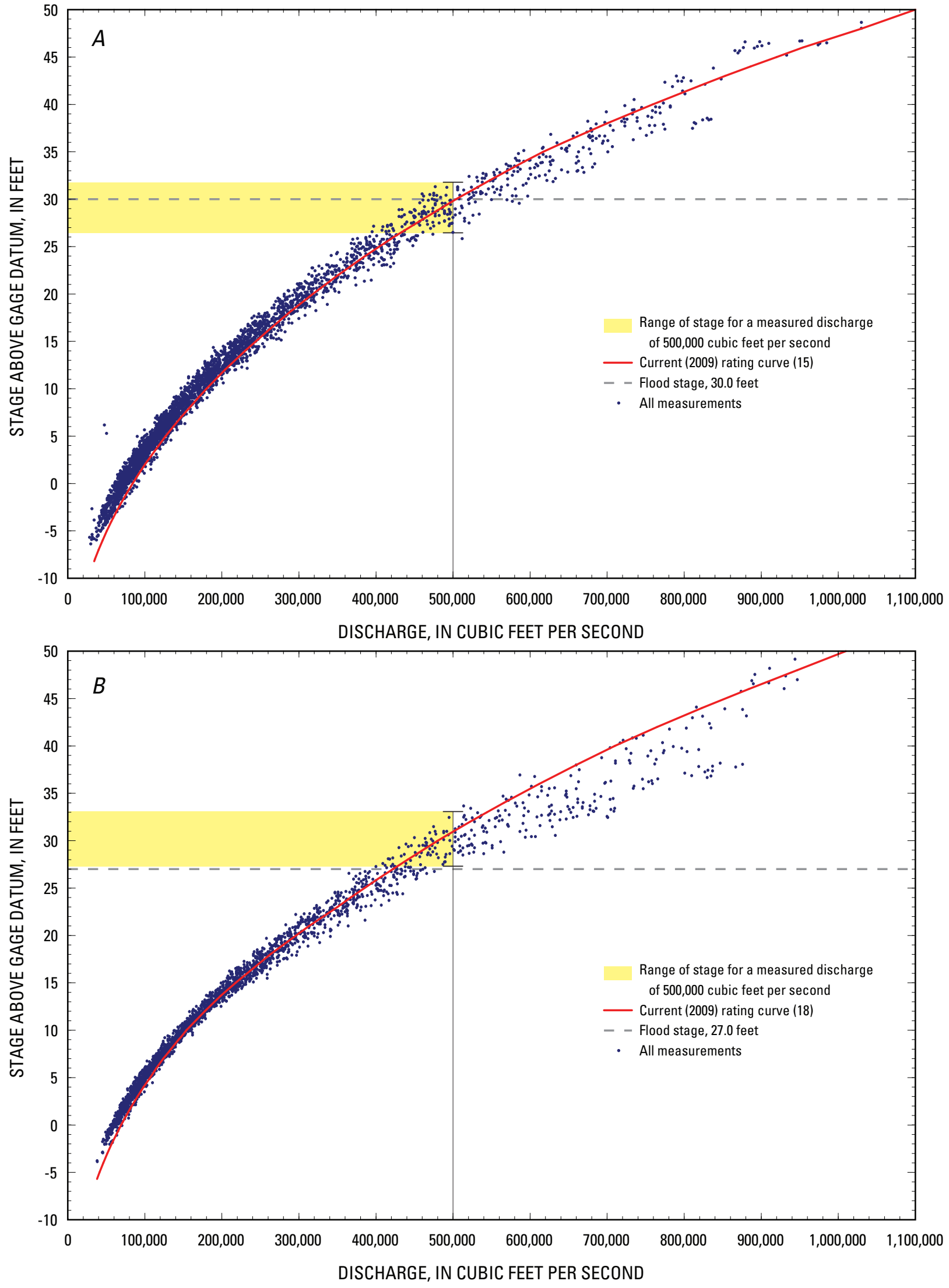

Figure 4. Stage and discharge from measurements made at the streamgages at (A) St. Louis, Missouri, and $(B)$ Chester, Illinois, on the Middle Mississippi River. 
rating is in the middle of measurements greater than 850,000 $\mathrm{ft}^{3} / \mathrm{s}$, or the stage for a given measured discharge greater than $850,000 \mathrm{ft}^{3} / \mathrm{s}$ currently (2009) will be in the middle of the range for which it has been measured historically.

Pinter and others (2001) and Brauer (2009) have shown that the variation in measured stage for a given discharge is somewhat time-dependent; measured stage plotted with time for the distinct discharge ranges shown in table 2 are shown in figure 5, and general changes with time become apparent. At the St. Louis gage, stages for discharges up to 400,000 $\mathrm{ft}^{3} / \mathrm{s}$ appear to be decreasing with time, whereas stages for discharges above $400,000 \mathrm{ft}^{3} / \mathrm{s}$ appear to be increasing. At the Chester gage, stages for discharges up to $300,000 \mathrm{ft}^{3} / \mathrm{s}$ appear to be decreasing with time, whereas stages for discharges of $300,000 \mathrm{ft}^{3} / \mathrm{s}$ and greater appear to be increasing.

The apparent decrease of stage with time for smaller discharges at the St. Louis and Chester gages (fig. 5) likely is caused by dikes in the channel. As mentioned previously, dikes work either by diverting flow around the structure, which generally increases velocities and causes the channel to deepen off the end of the dike while creating an area of slack water downstream from the dike, or by reducing flow velocities along the bank as flow passes through notches in the dike or through the dike structure. The mechanism for the first method is rooted in the concept of conservation of mass (Chow, 1959): for a given discharge, a reduction in flow area results in an increase in velocity. Placing dikes in the channel reduces the channel cross-section area for the lower flow conditions up to the crest of the dikes (approximately onehalf bankfull). The reduction of area at lower flows results in increased velocities off the end of the dike, and in an alluvial system such as the MMR, the increased velocities result in increased sediment transport, which subsequently increases the area of flow off the end of the dike. With time, velocity and area changes develop a dynamic equilibrium that tends to maintain a narrow, deeper low-flow channel (Smith and Winkley, 1996). This is reflected in the decrease of stage with time for smaller discharges at the St. Louis and Chester gages (fig. 5). For flow conditions greater than the crest of the dikes (approximately one-half bankfull) up to bankfull, water can flow in the full channel area, minus the area blocked by the dike, plus the additional area resulting from channel deepening off the end of the dikes.

Another factor that may contribute to the decrease of stage with time for smaller discharges is the decrease in sediment load available for transport on the Mississippi caused by upstream reservoirs on the main stem tributaries, and channel bed and bank stabilization projects on the MMR. Studies on the Lower Mississippi River indicate that there have been substantial reductions in the amount of sediment transported in the Mississippi River, resulting from sediment being trapped by reservoirs on the main stem tributaries of the Mississippi River, and less sediment being available from bank caving caused by natural meandering of a river (Kesel, 2003; Horowitz, 2006). Less sediment transport from upstream into the MMR would result in long-term lowering of the bed with time, as sediment removed from the MMR would not be replaced by incoming sediment.

The apparent increase of stage with time for larger discharges at the St. Louis and Chester gages (fig. 5) may be caused by levees that have been built on the flood plains. The transitional discharge from decreasing to increasing stage with time is approximately $400,000 \mathrm{ft}^{3} / \mathrm{s}$ at the St. Louis gage, and approximately $300,000 \mathrm{ft}^{3} / \mathrm{s}$ at the Chester gage. The stage associated with these discharges (approximately $25 \mathrm{ft}$ at St. Louis and $22 \mathrm{ft}$ at Chester) is 5 to $6 \mathrm{ft}$ less than bankfull, or flood stage, at their respective streamgages ( $30.0 \mathrm{ft}$ at $\mathrm{St}$. Louis and $27.0 \mathrm{ft}$ at Chester). The stage for a given discharge above flood stage at both streamgages was higher after the completion of the Alton-Gale levee system in the mid-1960s (fig. 5). Some of the increase in stage for a given discharge above flood stage before the mid-1960s may be the result of the numerous small levees built by private interests on the flood plains before that time. Although most of these levees were overtopped by the moderate to large floods from the 1920 s to the early 1950s (Gary Dyhouse, U.S. Army Corps of Engineers, written commun., 2009), their presence would nevertheless result in a decrease in the cross-sectional area of the flood plain up to the stage at which they were overtopped. Often, each flood would prompt the raising and strengthening of the overtopped levees (Gary Dyhouse, U.S. Army Corps of Engineers, written commun., 2009), which would decrease the cross-sectional area of the flood plain up to higher stages, resulting in an increase in stage for a given discharge.

\section{Stage-Discharge Relations from Rating Curves through Time}

The rating is built from discharge measurements at a variety of stages (fig. 4). It is not uncommon for a particular measurement to be somewhat different from the rating in use at the time because of seasonal variations, and a temporary shift may be applied to a part of the rating until such time that measurements indicate controlling flow conditions have returned to a previous condition. Measurements that are systemically off the rating indicate that a change in the controlling flow conditions has occurred, and a new rating that accurately reflects the existing flow conditions may be needed. Periods of major flooding often lead to the systemic channel changes that result in a new rating.

The various rating curves used at the St. Louis and Chester gages for the period of record under USGS operation are shown in figure 6 . The USGS began a system of numbering rating curves in the late 1950s; before this, ratings were referred to by date. In this study, these dated ratings were assigned a letter to assist in distinguishing them from one another, as some of these early ratings were used for parts of a year to address seasonal variations from temperature, vegetation, or channel changes. For example, rating " $\mathrm{H}$ " at the St. Louis gage was used from October 1, 1944, to September 31, 1945, and again from April 29 to June 24, 1947, and once 

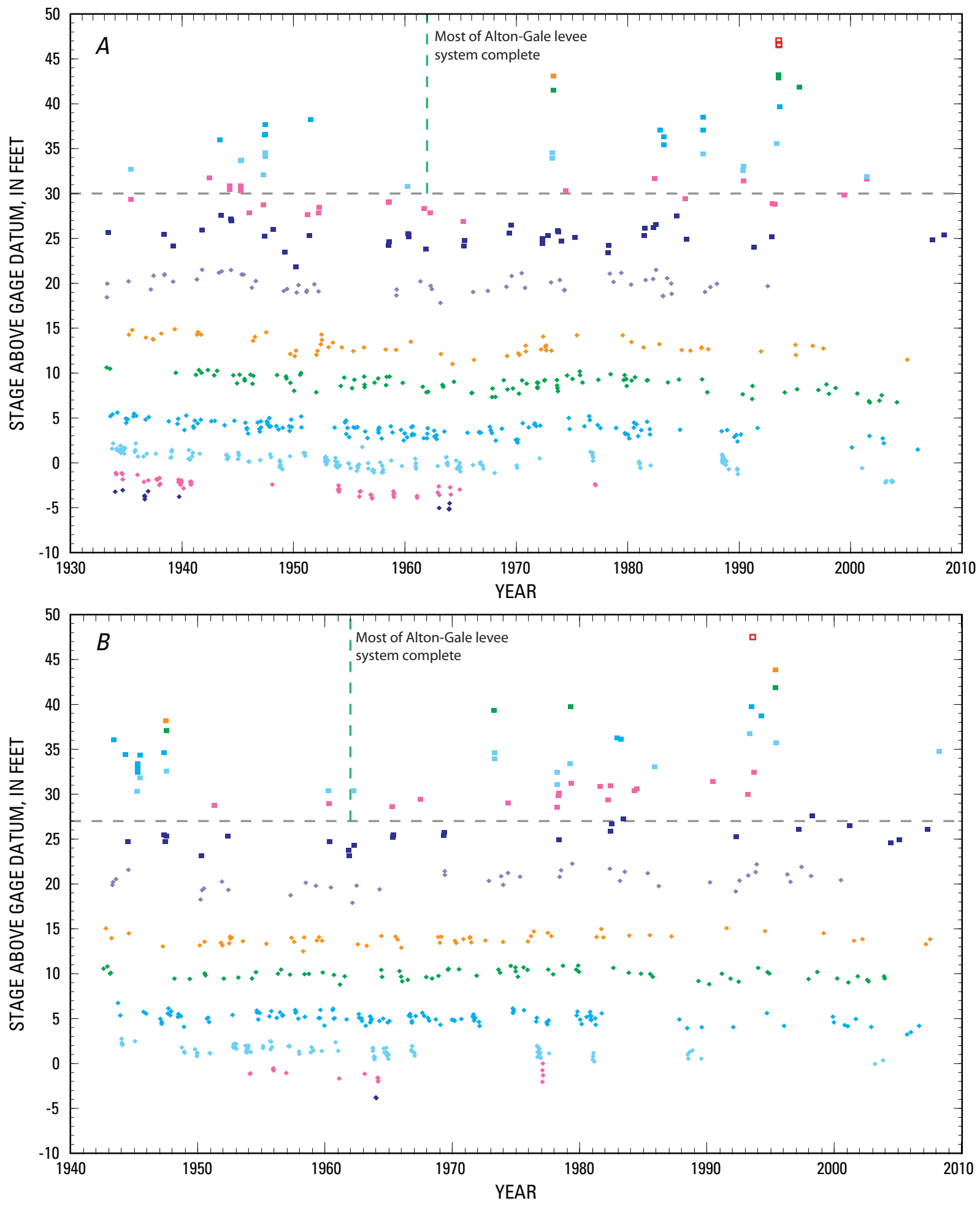

EXPLANATION
- Flood stage at streamgage
150,000 cubic feet per second +/- 5 percent $\quad$ - 600,000 cubic feet per second $+/-2$ percent
- 40,000 cubic feet per second +/- 5 percent
700,000 cubic feet per second $+/-1.5$ percent
- 50,000 cubic feet per second $+/-5$ percent
300,000 cubic feet per second $+1-2.5$ percent
- 800,000 cubic feet per second $+/-1$ percent
- 70,000 cubic feet per second $+/-5$ percent
- 400,000 cubic feet per second $+/-2.5$ percent
850,000 cubic feet per second +/- 1 percent
- 100,000 cubic feet per second $+/-5$ percent
- 500,000 cubic feet per second +/- 2 percent
a 900,000 cubic feet per second $+/-1$ percent

Figure 5. Stage for a given discharge range with time from measurements made at the streamgages at $(A)$ St. Louis, Missouri, and $(B)$ Chester, Illinois, on the Middle Mississippi River. 
again from January 1 to May 5, 1948. The letter or number of the rating, followed by the year (or part of a year) that it started being used, are shown in figure 6 .

As was observed with the measurement data for the period of record (fig. 4), there is a broad range of stages for any given discharge from the ratings through time as well (fig. 6); however, because a rating is a best-fit relation between measured stage and discharge, it is anticipated that there is some "smoothing" effect that removes the variability of individual measurements of stage at a given discharge. Plotting the value of stage for a given discharge from the various ratings through time (fig. 7) appears to give similar results to what were obtained with individual measurements (fig. 5); however, at the St. Louis gage (fig. $7 A$, table 3), several important features are evident in the rating data that are not readily apparent in the measurement data. First, for all discharges less than $400,000 \mathrm{ft}^{3} / \mathrm{s}$, the gage height from the most recent rating " 15 " is less than the first rating " $A$ ", which indicates a lowering of gage heights with time for all discharges less than $400,000 \mathrm{ft}^{3} / \mathrm{s}$. A few intervening ratings (ratings 4, 7, and 11) have gage heights greater than the first rating " $A$ " for a given discharge less than $400,000 \mathrm{ft}^{3} / \mathrm{s}$, but, ultimately, gage heights have all decreased with time for discharges less than $400,000 \mathrm{ft}^{3} / \mathrm{s}$. Two of the ratings with greater gage heights, ratings "7" and "11", were started in response to the 1973 and 1993 floods, and these extreme floods apparently had a substantial but temporary effect on the controlling flow conditions. Second, for discharges of $900,000 \mathrm{ft}^{3} / \mathrm{s}$ or greater, the gage height from the most recent rating (15) is less than the first rating (10) for which these high discharges were available. Rating " 10 " had been extrapolated to a gage height of $50 \mathrm{ft}$ in 1988 based on the highest discharge measurement then available $\left(848,000 \mathrm{ft}^{3} / \mathrm{s}\right.$, made in 1973) but without the aid of direct measurements of discharge above $848,000 \mathrm{ft}^{3} / \mathrm{s}$. The 1993 flood provided the opportunity to make actual direct measurements of discharge above this threshold, and based on these direct observations, it was realized that the extrapolation of rating " 10 " resulted in stages that were too high for a given discharge. Thus, rating " 11 " and those that followed made corrections to show a lower stage for the same discharge. Finally, since the mid-1960s at the St. Louis gage, the rated stage for a given discharge has either remained constant or decreased with time for all discharges (table 3 ). There is a noticeable increase in stage for discharges of $700,000 \mathrm{ft}^{3} / \mathrm{s}$ or greater after the completion of the Alton-Gale levee system in the mid1960s; indeed, there is some increase between 1946 and 1962 while much of the federal levee project was under construction (see rating $\mathrm{N}$, fig. $7 A$ ); however, levee construction has been negligible in the MMR since the completion of the Alton-Gale levee system in the mid-1960s.

Similar to the St. Louis gage, the rating data for the Chester gage indicate several important features that are not readily apparent from the measurement data (fig. $7 B$, table 4). There are noticeable increases in gage height for discharges greater than $500,000 \mathrm{ft}^{3} / \mathrm{s}$, such as between ratings " 8 " and " 10 " in the early 1970 s, and between ratings " 13 " and " 14 " in the early 1990s. Ratings " 10 " and " 14 " were started in response to the 1973 and 1993 floods, and, like the St. Louis gage, these extreme floods apparently had a substantial effect on the controlling flow conditions. Unlike the St. Louis gage, however, the flood effects were not temporary for discharges greater than $600,000 \mathrm{ft}^{3} / \mathrm{s}$. Also unlike the St. Louis gage., the rated stage for a given discharge greater than $500,000 \mathrm{ft}^{3} / \mathrm{s}$ at the Chester gage has been steadily increasing with time (fig. $7 B$, table 4). The apparent decrease of rated stage with time for a given discharge below $150,000 \mathrm{ft}^{3} / \mathrm{s}$ at the Chester gage likely is caused by the dikes in the channel and decreased sediment loads in the MMR; however, the increase of rated stage with time for a given discharge above $500,000 \mathrm{ft}^{3} / \mathrm{s}$ cannot be fully explained by the presence of levees on the flood plains near the Chester gage, given the apparent increase in rated stage for a given discharge after completion of the Alton-Gale levee system in the mid-1960s.

\section{Top Width from Measurements}

Each direct discharge measurement has a measured top width of flow, which is the distance from one edge of the flow to the other along the measurement section. The top width of flow from measurements with discharge are shown in figure 8. For the St. Louis gage (fig. $8 A$ ), there are two distinct bands of data, plus a smattering of other points. The bands are a result of two measurement locations existing for the period of record at the St. Louis gage. Measurements made from the Municipal/MacArthur Bridge for flows contained in the main channel form the lower band of data, with the scattered points high in the plot representing increased flows that resulted in flow on the left flood plain under the bridge. Measurements made from the monorail on the Poplar Street Bridge form the upper band of data and have a distinct upper boundary at 2,340 ft, which is the distance between the abutments of the main span of the bridge. Generally, measurements using ADCPs have been made in the open channel just downstream from the Eads Bridge, or approximately $0.5 \mathrm{mi}$ upstream from the Eads Bridge (Hugh Edwards, U.S. Geological Survey, oral commun., 2009). Because the Mississippi channel is relatively uniform through this part of St. Louis and the Municipal/ MacArthur Bridge does not create a substantial constriction to the channel or flood plain, the measurements made using ADCPs plot among the data from measurements made from the Municipal/MacArthur Bridge, even though they are not made at the bridge location. The high outlier at approximately $136,000 \mathrm{ft}^{3} / \mathrm{s}$ is from a measurement made using an ADCP at a section of the channel near the USACE service base at the foot of Arsenal Street that was substantially wider than the channel near the gage (Robert Holmes, Jr., U.S. Geological Survey, written commun., 2009). The measurements with top widths at or below $1,400 \mathrm{ft}$ generally are measurements made when sand bars were present in the channel. 

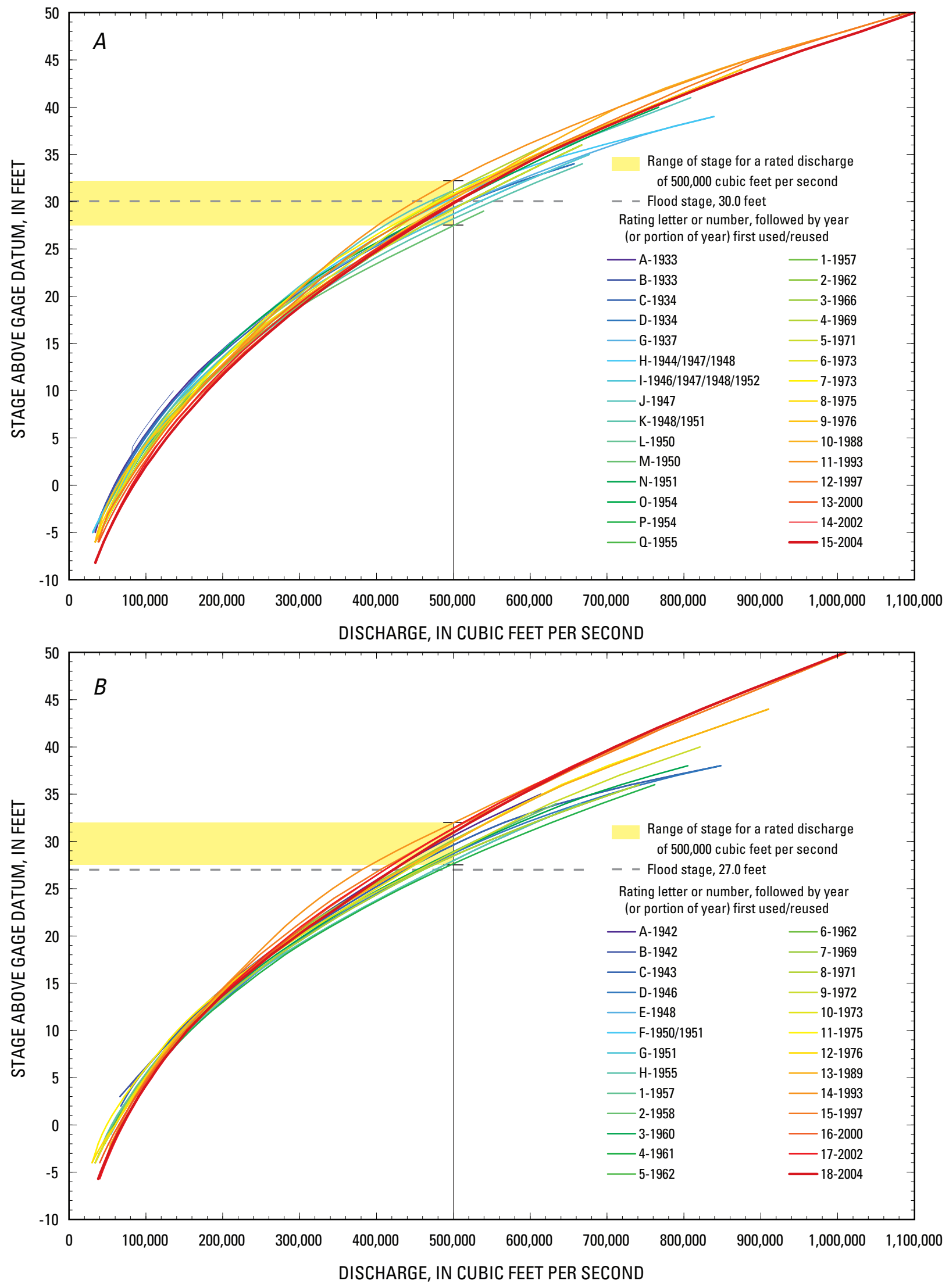

Figure 6. Ratings from the streamgages at $(A)$ St. Louis, Missouri, and $(B)$ Chester, Illinois, on the Middle Mississippi River. 


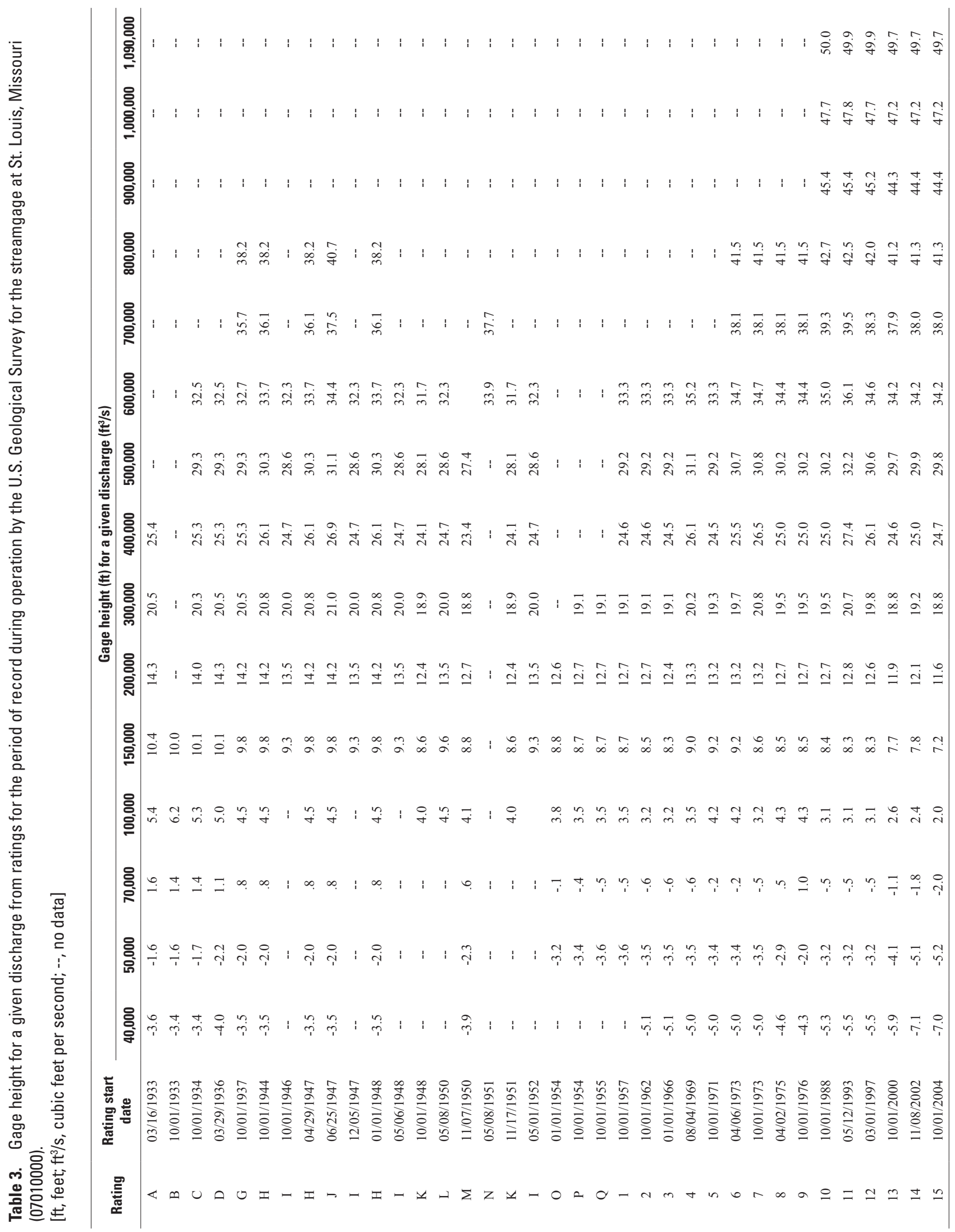



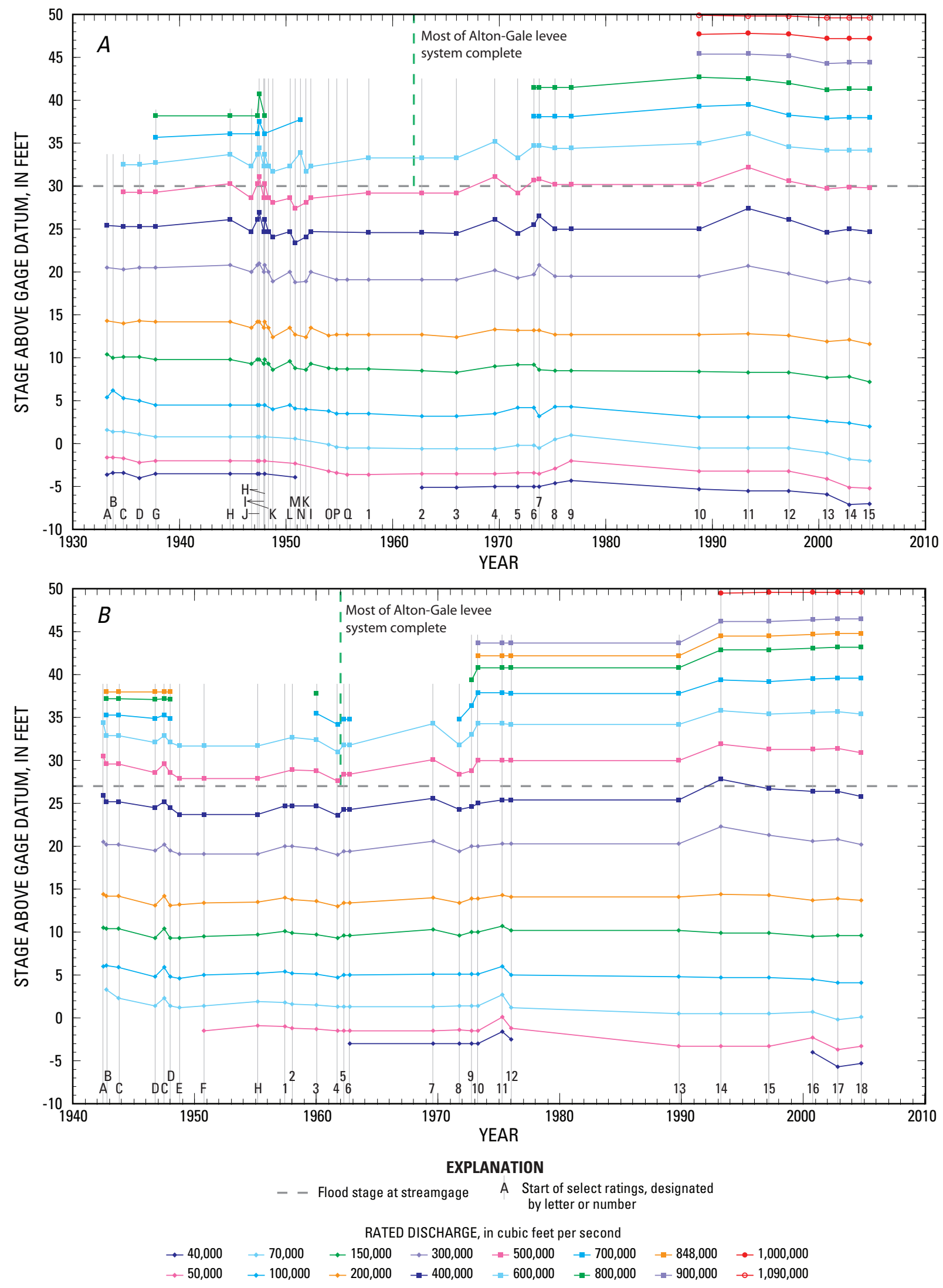

Figure 7. Rated stage for a given discharge with time from ratings at the streamgages at $(A)$ St. Louis, Missouri, and $(B)$ Chester, Illinois, on the Middle Mississippi River. 


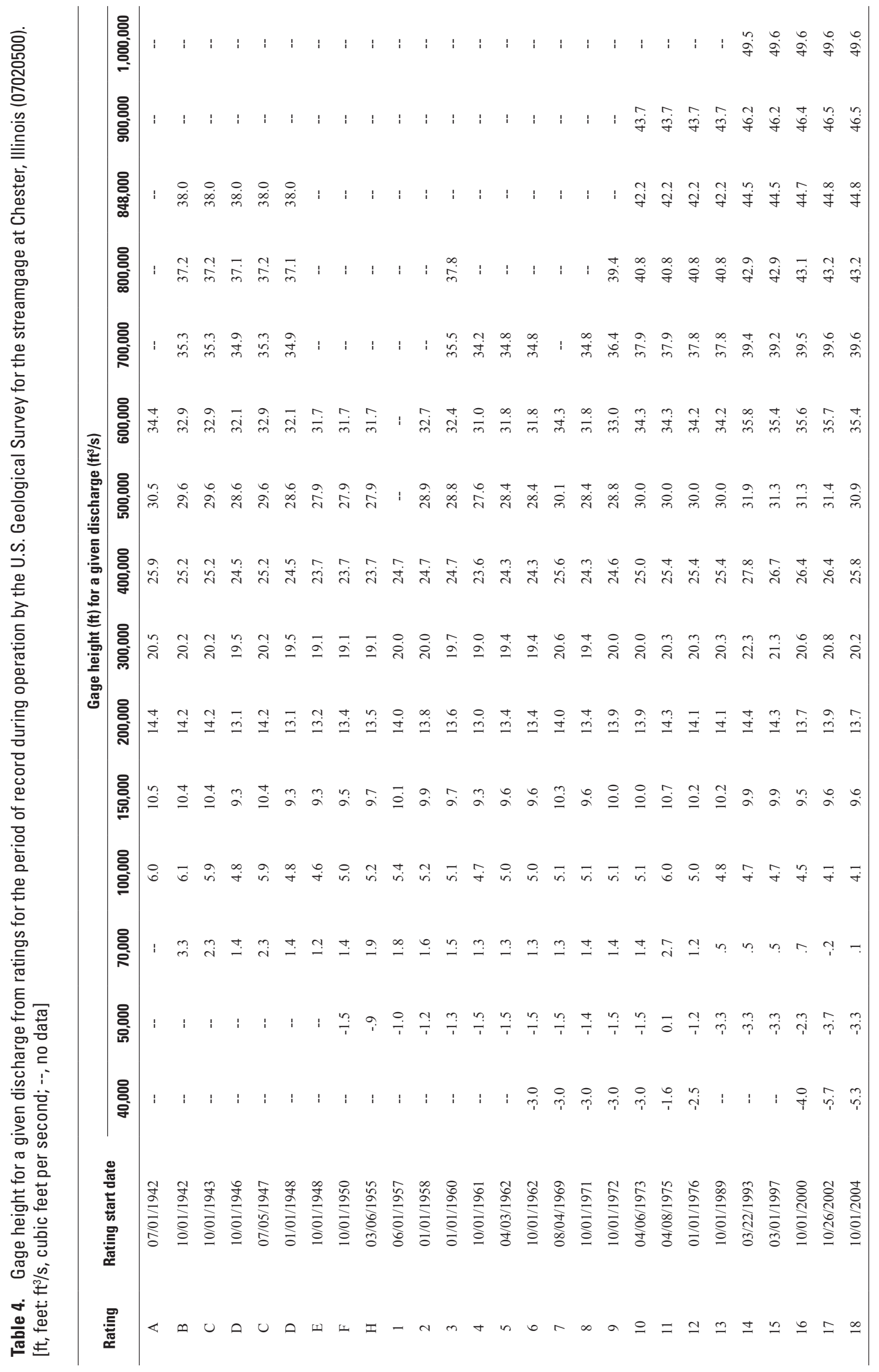



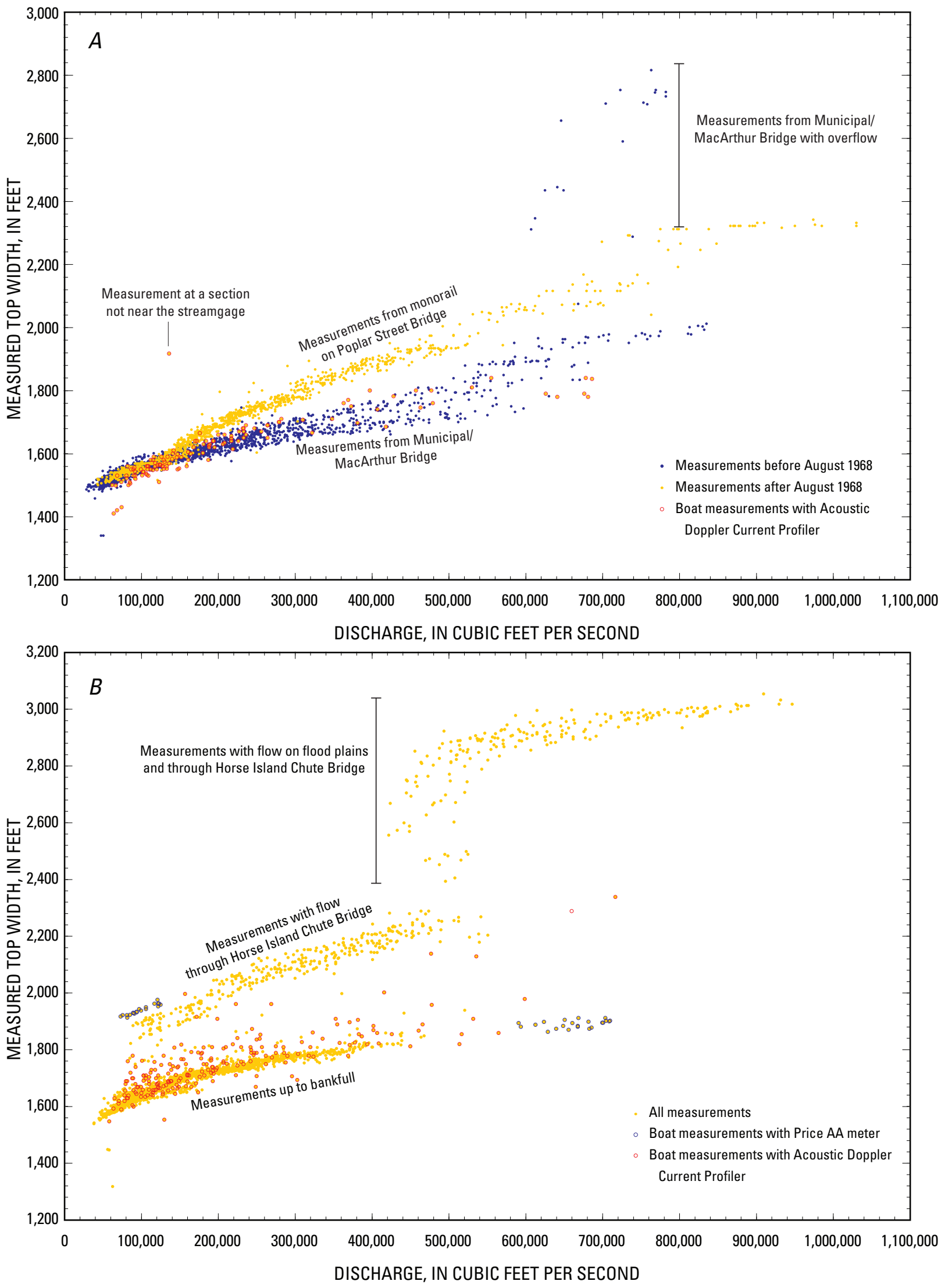

Figure 8. Measured top width and discharge from measurements made at the streamgages at $(A)$ St. Louis, Missouri, and $(B)$ Chester, Illinois, on the Middle Mississippi River. 
For the Chester gage (fig. $8 B$ ), there are three distinct bands of data. With the exception of boat measurements, all other measurements have been made from the Chester Bridge. Measurements up to bankfull conditions form the lower band, measurements with some amount of additional flow through the Horse Island Chute Bridge form the middle band, and measurements with discharge through the bridges and on the flood plain between the bridges form the scattered upper band. Although it is not unusual to have a relief bridge at a gage site, it is somewhat unusual to have such a broad band of data (from 80,000 to $700,000 \mathrm{ft}^{3} / \mathrm{s}$, nearly an order of magnitude) where flow can be said to be either completely contained in the main channel, or in the main channel and the overflow channel. When measured top width with discharge is plotted for various time intervals related to the ratings (fig. 9), transitions appear. For the period covering ratings " $\mathrm{A}$ " through "D" from July 1942 to September 1948 (fig. 9A), only the smallest discharges were contained within the main channel alone, and flow was measured in Horse Island Chute starting at approximately $80,000 \mathrm{ft}^{3} / \mathrm{s}$. A notable exception occurred during the flood of April 1945, during which discharge measurements were obtained by boat. The top width of these boat measurements is commensurate with other, much lower discharge measurements also obtained by boat from 1944 to 1946 (fig. $9 A$ ). Boat measurements were necessary because the bridge had collapsed during a tornado in 1944 , and were obtained approximately $1 \mathrm{mi}$ downstream from the bridge at a constriction in the channel, downstream from where Horse Island Chute joins the main channel. During the period covering ratings "A" through " $\mathrm{D}$ ", flow on the flood plains occurred above $500,000 \mathrm{ft}^{3} / \mathrm{s}$. One outlier, with a top width of $1,755 \mathrm{ft}$ and a discharge of $332,000 \mathrm{ft}^{3} / \mathrm{s}$, is marked as not including flow in Horse Island Chute on the measurement notes (fig. 9A).

For the period covering ratings " $\mathrm{E}$ " and " $\mathrm{F}$ " from October 1948 to March 1955 (fig. 9B), the range of flows contained in the main channel increased to $300,000 \mathrm{ft}^{3} / \mathrm{s}$, with numerous discharge measurements in Horse Island Chute in the range from 150,000 to $450,000 \mathrm{ft}^{3} / \mathrm{s}$ during this time. Flow on the flood plains began occurring at $430,000 \mathrm{ft}^{3} / \mathrm{s}$. For the period covering ratings " $\mathrm{H}$ " through " 9 " from March 1955 to April 1973 (fig. 9C), the range of flows contained in the main channel increased slightly to $320,000 \mathrm{ft}^{3} / \mathrm{s}$, with a slight decrease in the range of flows in Horse Island Chute; flow on the flood plains continued to occur at approximately 430,000 $\mathrm{ft}^{3} / \mathrm{s}$. Occasional measurements during this period include an estimate of flow in Horse Island Chute at lower discharges, resulting in several outliers below $250,000 \mathrm{ft}^{3} / \mathrm{s}$ (fig. 9C).

For ratings "10" through " 18 " from April 1973 to the December 2008 (fig. 9D), flows up to 500,000 $\mathrm{ft}^{3} / \mathrm{s}$ were contained in the main channel, with some flows between 300,000 and $500,000 \mathrm{ft}^{3} / \mathrm{s}$ being transitional to flow through Horse Island Chute Bridge and on the flood plains. Generally, measurements made using ADCPs occur approximately $0.5 \mathrm{mi}$ downstream from the Chester Bridge, near the constriction in the channel, downstream from where Horse Island Chute joins the main channel (Hugh Edwards, U.S. Geological Survey, oral commun., 2009). The various measurements made using ADCPs plot as scatter in the range between the measurements with main channel flow only and those with flow in Horse Island Chute (fig. $8 B$ and $9 D$ ) because the measured discharge is the total discharge, including flow through Horse Island Chute Bridge, if any.

The change in the transitional discharges shown in figure 9 implies that the conditions under which flow occurs in Horse Island Chute had changed with time. In the mid 1940s, flow occurred in the chute at any discharge more than approximately $100,000 \mathrm{ft}^{3} / \mathrm{s}$, whereas by 1973 , flow occurred in the chute only for discharges more than $300,000 \mathrm{ft}^{3} / \mathrm{s}$. The inlet to Horse Island Chute or to the old river channel that connects Horse Island Chute with the main channel upstream from the Chester gage appears to be filling in, such that the stage required to initiate flow in Horse Island Chute has been increasing with time. This is consistent with findings on the Lower Mississippi River (LMR) by Smith and Winkley (1996), who determined that the complex of abandoned chutes and channels on the flood plains within the mainline levees of the river are "sinks" for suspended sediment. During falling stages of overbank flow, suspended sediment is trapped in these riparian water bodies, resulting in rapid sedimentation (Smith and Winkley, 1996). Huizinga and Rydlund (2001) determined that the Horse Island Chute channel under the bridge aggraded nearly $10 \mathrm{ft}$ between 1942 and 1961 based on an examination of discharge measurements in the Chute.

The amount of flow in Horse Island Chute has a direct effect on values measured or computed from measurements at the Chester gage because flow in an overflow channel increases the discharge, area, and top width of a measurement; however, if the conditions to initiate flow in the overflow channel change with time, the additional discharge, area, and top width also will change with time, which can have a profound effect on measurements near the conditions required to initiate flow in the overflow channel. At the initiation of flow in the overflow channel, there often is a substantial increase in the measured area and top width with a relatively small change in stage or discharge, which causes average quantities computed from the measured quantities (such as average velocity computed from measured discharge and area) to be substantially less than for a similar in-channel discharge. As flow increases through the overflow channel, the discharge, area, and top width become more proportional to flow in the main channel, but often will continue to have an effect on average quantities computed from the measured quantities. Furthermore, quantities derived from measurements at a given stage or discharge will change with time as the conditions to initiate flow on a flood plain or in an overflow channel change. This change with time may contribute to the increase in rated gage height for a given discharge observed at the Chester gage after the completion of the Alton-Gale levee system in the mid1960s (fig. 7B) that was not seen at the St. Louis gage (fig. $7 A$ ). 


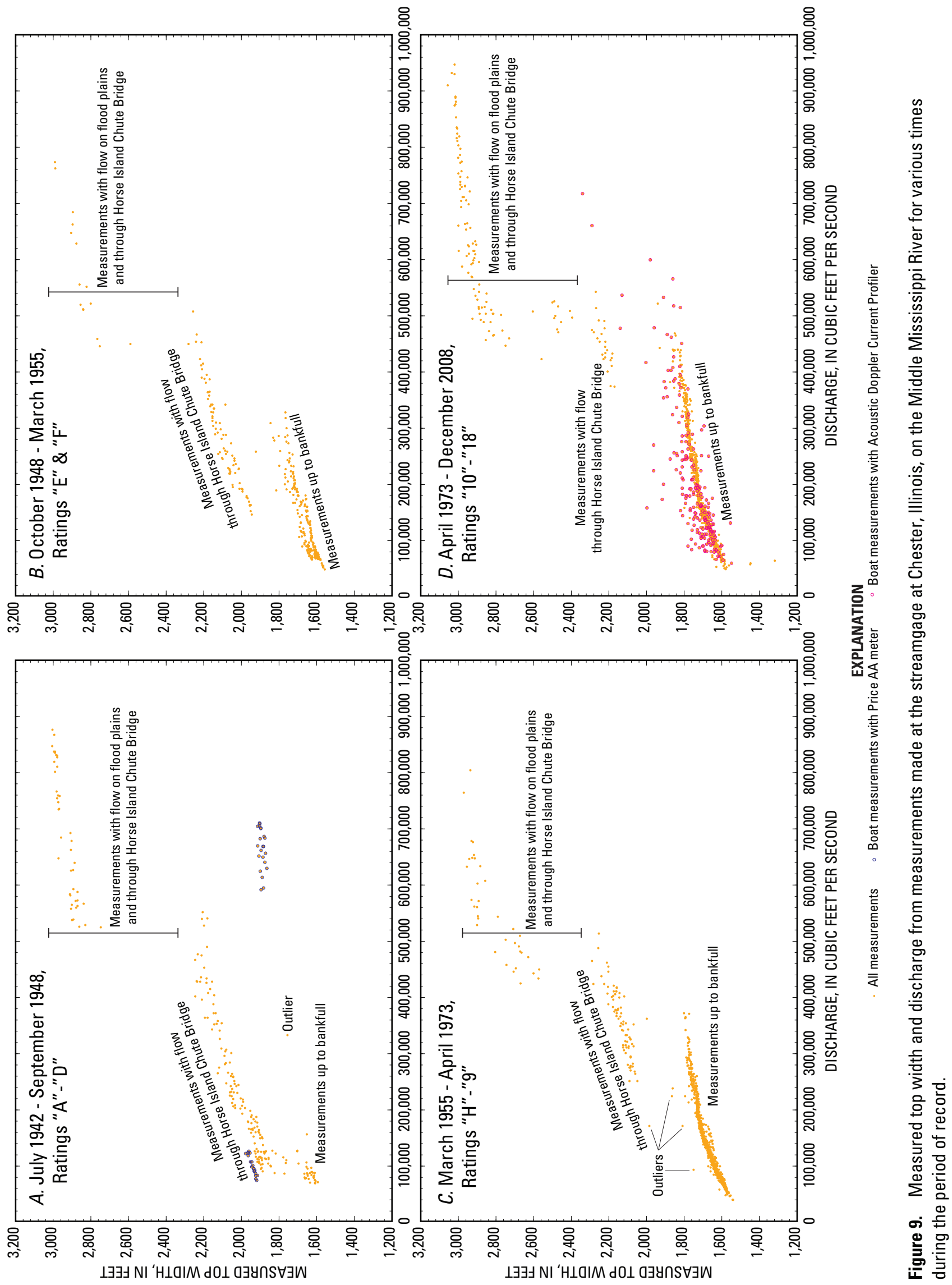


Therefore, in the analyses that follow, the effects of the changing inlet conditions for flow in Horse Island Chute were mitigated by removing the part of the flow (discharge, area, and top width) measured in Horse Island Chute for flows with stages less than flood stage. The notes from individual discharge measurements were examined to determine the part of the discharge, area, and top width that was contributed by flow in Horse Island Chute; this part was subtracted from the total discharge, area, and top width to create adjusted values.

The top width from measurements with time for the discharge ranges $100,000 \mathrm{ft}^{3} / \mathrm{s}+/-5$ percent, $400,000 \mathrm{ft}^{3} / \mathrm{s}+/$ 2.5 percent, and $600,000 \mathrm{ft}^{3} / \mathrm{s}+/-2$ percent at the St. Louis and Chester gages are shown in figure 10. These three discharge ranges were chosen because they have a reasonably substantial number of measurements at both streamgages (table 2), and represent flow conditions that likely would be affected by dikes $\left[100,000 \mathrm{ft}^{3} / \mathrm{s}\right.$ is between low flow and one-half bankfull (figs. 5 and 7)], moderate flood conditions that generally are contained within the main channel $\left[400,000 \mathrm{ft}^{3} / \mathrm{s}\right.$ occurs at stages that are less than flood stage for both streamgages (figs. 5 and 7)], and larger flood conditions that are not contained within the main channel $\left[600,000 \mathrm{ft}^{3} / \mathrm{s}\right.$ occurs at stages that are greater than flood stage for both streamgages (figs. 5 and 7)]. Boat measurements are not shown, because the measurement location is not consistent with the measurements made from the bridges at the streamgages, resulting in incompatible values of top width.

Measured top widths at the St. Louis gage (fig. 10A) demonstrate a relatively constant average value of $1,560 \mathrm{ft}$ for the $100,000 \mathrm{ft}^{3} / \mathrm{s}$ range at both measurement locations, whereas the top width at the Poplar Street Bridge is approximately $175 \mathrm{ft}$ greater than the Municipal/MacArthur Bridge for the $400,000 \mathrm{ft}^{3} / \mathrm{s}$ range. However, there was a decrease in the measured top width at the Municipal/MacArthur Bridge for the $400,000 \mathrm{ft}^{3} / \mathrm{s}$ range, from an approximate average of $1,750 \mathrm{ft}$ before 1945 to an approximate average of $1,700 \mathrm{ft}$ after 1945, perhaps as a result of the floods in 1943, 1944, and 1947 (fig. 10A). There was a substantial amount of variability in the $100,000 \mathrm{ft}^{3} / \mathrm{s}$ range during this time at the St. Louis gage as well, which appeared to stabilize after the flood of 1951 (fig. 10A). The measured top width for the $600,000 \mathrm{ft}^{3} / \mathrm{s}$ range at the Municipal/MacArthur Bridge decreased from 2,311 ft in 1935 to approximately $1,900 \mathrm{ft}$ in the mid $1940 \mathrm{~s}$, and further decreased to $1,743 \mathrm{ft}$ in 1960. The first measurement in 1935 included $490 \mathrm{ft}$ of shallow, slow flow on the left overbank under the bridge, which was not present or left out of later measurement as inconsequential to the total flow. The measured top width for the $600,000 \mathrm{ft}^{3} / \mathrm{s}$ range at the Poplar Street Bridge has fluctuated slightly around the approximate average value of $2,060 \mathrm{ft}$.

Top widths from measurements made at the Chester gage (fig. 10B) are remarkably consistent through time for all three discharge ranges when the data for the $100,000 \mathrm{ft}^{3} / \mathrm{s}$ and $400,000 \mathrm{ft}^{3} / \mathrm{s}$ discharge ranges are adjusted to remove the part of the flow in Horse Island Chute. The period of record average top width is approximately $1,640 \mathrm{ft}$ for the 100,000 $\mathrm{ft}^{3} / \mathrm{s}$ range, approximately $1,820 \mathrm{ft}$ for the $400,000 \mathrm{ft}^{3} / \mathrm{s}$ range, and approximately $2,910 \mathrm{ft}$ for the $600,000 \mathrm{ft}^{3} / \mathrm{s}$ range. Unadjusted top widths (including Horse Island Chute flow) from measurements in the $100,000 \mathrm{ft}^{3} / \mathrm{s}$ range change from approximately $1,900 \mathrm{ft}$ in the 1940 s to approximately $1,640 \mathrm{ft}$ after 1950. Unadjusted top widths for the $400,000 \mathrm{ft}^{3} / \mathrm{s}$ range are approximately $2,200 \mathrm{ft}$ until 1970 , at which time they change to approximately $1,800 \mathrm{ft}$. The change in the unadjusted top widths indicates that flow in Horse Island Chute has not been measured for the $100,000 \mathrm{ft}^{3} / \mathrm{s}$ range since the late $1940 \mathrm{~s}$, and for the $400,000 \mathrm{ft}^{3} / \mathrm{s}$ range since 1970 , except for once in 1982 (fig. 10B), which is consistent with the results discussed earlier in this report (fig. 9) and with sediment filling the inlet to the chute with time (Smith and Winkley, 1996). Measured top widths for the $600,000 \mathrm{ft}^{3} / \mathrm{s}$ range always have included flow in Horse Island Chute, as there is flow on the right flood plain at that discharge (fig. $8 B$ ).

\section{Changes in Average Velocity from Measurements with Time}

The average velocity from measurements with time for the discharge ranges $100,000 \mathrm{ft}^{3} / \mathrm{s}+/-5$ percent, $400,000 \mathrm{ft}^{3} / \mathrm{s}$ $+/-2.5$ percent, and $600,000 \mathrm{ft}^{3} / \mathrm{s}+/-2$ percent at the St. Louis and Chester gages are shown in figure 11. Once again, boat measurements are not shown, because the measurement location is not consistent with the measurements made from the bridges at the streamgages, resulting in incompatible values. Average velocities from measurements made at the St. Louis gage (fig. $11 \mathrm{~A}$ ) fluctuate approximately 0.5 feet per second $(\mathrm{ft} / \mathrm{s})$ around an average value of $2.90 \mathrm{ft} / \mathrm{s}$ for the $100,000 \mathrm{ft}^{3} / \mathrm{s}$ range at the Municipal/MacArthur Bridge, whereas average velocities from measurements at the Poplar Street Bridge display much more variability until 1977 , and stabilize with time around an average value of $3.14 \mathrm{ft} / \mathrm{s}$. Two unusually high average velocities were measured at the Poplar Street Bridge in February 1970, which both have a stage value more than 1.5 $\mathrm{ft}$ lower than other stages measured for this discharge range. Average velocities for the $400,000 \mathrm{ft}^{3} / \mathrm{s}$ range have wider variability than the $100,000 \mathrm{ft}^{3} / \mathrm{s}$ range, fluctuating approximately $0.8 \mathrm{ft} / \mathrm{s}$ around the period of record average value of $5.73 \mathrm{ft} / \mathrm{s}$ at both locations. Average velocities for the $600,000 \mathrm{ft}^{3} / \mathrm{s}$ range fluctuate approximately $0.4 \mathrm{ft} / \mathrm{s}$ around the average values of $6.92 \mathrm{ft} / \mathrm{s}$ at the Municipal/MacArthur Bridge and $6.73 \mathrm{ft} / \mathrm{s}$ at the Poplar Street Bridge, with the exception of a high outlier in April 1960. This outlier had a stage value more than $2 \mathrm{ft}$ lower than other stages measured for this discharge range. Several of the abrupt decreases of average velocity for the $100,000 \mathrm{ft}^{3} / \mathrm{s}$ and $400,000 \mathrm{ft}^{3} / \mathrm{s}$ ranges appear to be the result of medium to large floods at the St. Louis gage (fig. 11A). An additional abrupt change observed in 1935 for the $100,000 \mathrm{ft}^{3} / \mathrm{s}$ range likely is the result of the smaller flood that occurred that year (table 1). Some of the variability also may be the result 

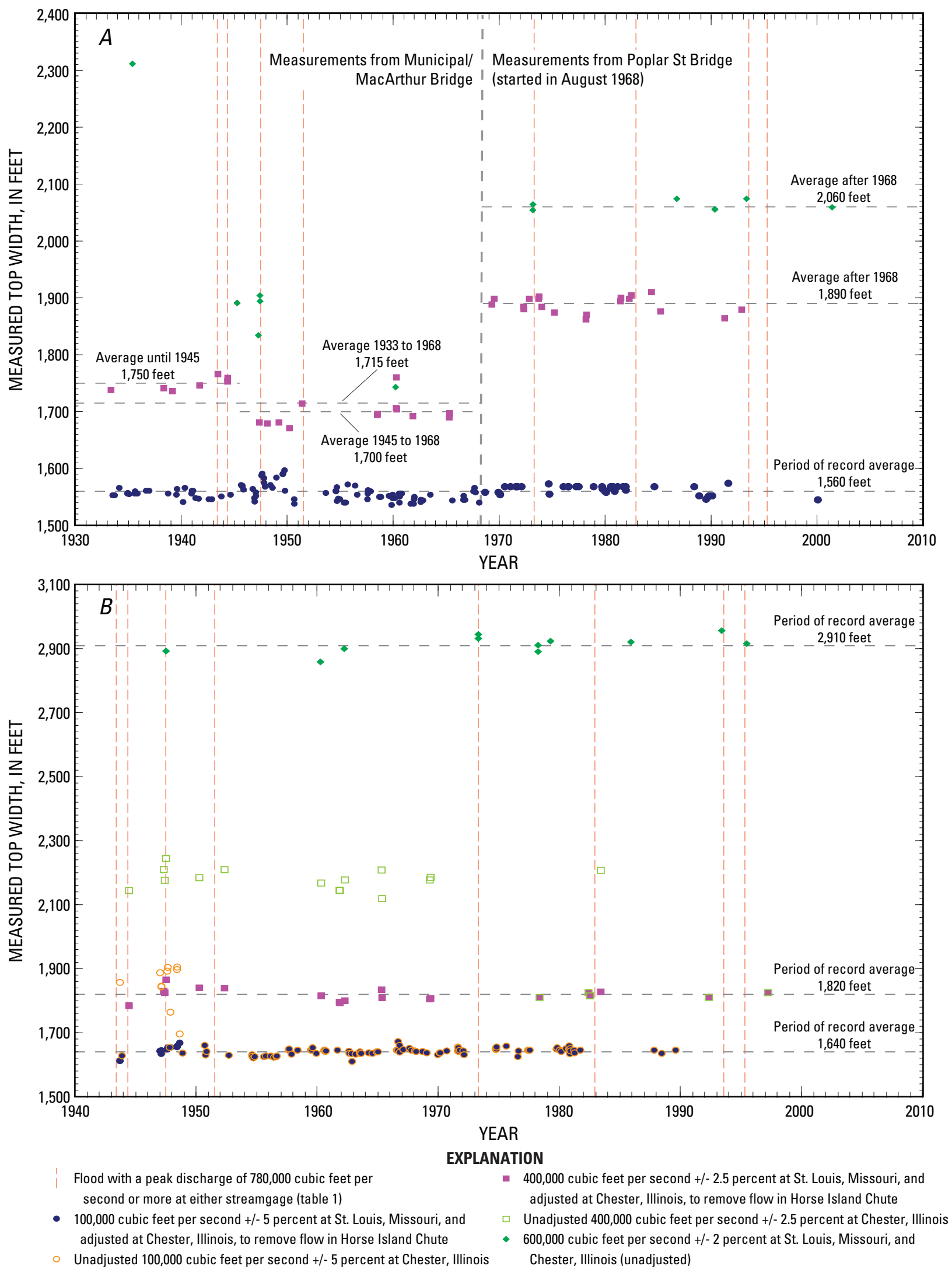

Figure 10. Measured top width for a given discharge range with time from measurements made at the streamgages at $(A)$ St. Louis, Missouri, and (B) Chester, Illinois, on the Middle Mississippi River. 
of where on the hydrograph the measurements were made, because the average velocity can be larger on the rising limb of the hydrograph than on the falling limb for a comparable discharge.

Unadjusted average velocities from measurements at the Chester gage for all three discharge ranges and average velocities adjusted to remove the part of the flow in Horse Island Chute for the $100,000 \mathrm{ft}^{3} / \mathrm{s}$ and $400,000 \mathrm{ft}^{3} / \mathrm{s}$ ranges are shown in figure $11 \mathrm{~B}$. For the $100,000 \mathrm{ft}^{3} / \mathrm{s}$ range, average velocities fluctuate approximately $0.5 \mathrm{ft} / \mathrm{s}$ around a period of record average value of $3.23 \mathrm{ft} / \mathrm{s}$ after 1949; average velocities before 1949 are all lower than the period of record average value, even when adjusted to remove the part of the flow in Horse Island Chute. Average velocities for the $400,000 \mathrm{ft}^{3} / \mathrm{s}$ range have wider variability than the $100,000 \mathrm{ft}^{3} / \mathrm{s}$ range, even when adjusted to remove the part of the flow in Horse Island Chute (fig. 11B), fluctuating approximately $0.7 \mathrm{ft} / \mathrm{s}$ around a period of record average value of $5.72 \mathrm{ft} / \mathrm{s}$. Average velocities for the $600,000 \mathrm{ft}^{3} / \mathrm{s}$ range fluctuate nearly $1 \mathrm{ft} / \mathrm{s}$ around the period of record average value of $6.29 \mathrm{ft} / \mathrm{s}$, and plot approximately $0.5 \mathrm{ft} / \mathrm{s}$ above the adjusted average velocities for the $400,000 \mathrm{ft}^{3} / \mathrm{s}$ range. The abrupt decrease in average velocity in 1948 at the Chester gage appears to be the result of the 1947 flood (fig. 11B); however, most of the other floods do not appear to have an impact on the average velocities at the Chester gage. Average velocities appear to be increasing with time at the Chester gage (fig. 11B) for in-channel flows, as most of the values are less than the period of record average value before about 1970 for the $100,000 \mathrm{ft}^{3} / \mathrm{s}$ and 400,000 $\mathrm{ft}^{3} / \mathrm{s}$ discharge ranges, and most of the values are greater than the period of record average value after 1970 for these discharge ranges. The average velocities for the $600,000 \mathrm{ft}^{3} / \mathrm{s}$ range do not appear to be increasing with time (fig. 11B). The higher average velocities after 1970 for in-channel flows may be the result of a series of dikes upstream from the Chester gage that were built or extended in the early 1970s (fig. 2). Several of the dikes are immediately upstream from the Chester Bridge, and the increased velocity in the channel at the dike field could have some effect on the channel at the bridge. The effect of the dike field on the average velocities appears to "wash out" for the $600,000 \mathrm{ft}^{3} / \mathrm{s}$ range, as the dikes are submerged by more than $15 \mathrm{ft}$ of water.

\section{Changes in Average Bed Elevation with Time}

Dividing the total measured area by the measured top width gives an average depth of flow. Subtracting the average depth of flow from the stage value for a measurement added to the gage datum provides an average bed elevation. The average bed elevation with time for the discharge ranges 100,000 $\mathrm{ft}^{3} / \mathrm{s}+/-5$ percent, $400,000 \mathrm{ft}^{3} / \mathrm{s}+/-2.5$ percent, and 600,000 $\mathrm{ft}^{3} / \mathrm{s}+/-2$ percent at the St. Louis and Chester gages is shown in figure 12. Once again, boat measurements are not shown, because the measurement location is not consistent with the measurements made from the bridges at the streamgages, resulting in incompatible values.

Average bed elevations from measurements made at the St. Louis gage (fig. 12A) fluctuate substantially at both locations for all three discharge ranges. Abrupt decreases in average bed elevation appear to be the result of medium to large floods at the St. Louis gage (fig. 12A). An additional abrupt change observed in 1935 for the $100,000 \mathrm{ft}^{3} / \mathrm{s}$ range likely is the result of the smaller flood that occurred that year (table 1). Generally, the average bed elevation appears to be lowering with time at both locations for all three discharge ranges (fig. 12A). The high average bed elevation at the Municipal/ MacArthur Bridge in April 1935 for the $600,000 \mathrm{ft}^{3} / \mathrm{s}$ range, and two unusually high average bed elevations at the Poplar Street Bridge in February 1970 for the 100,000 $\mathrm{ft}^{3} / \mathrm{s}$ range correspond to the high average velocities observed earlier (fig. $11 A$ ). Because the measured top width remains relatively consistent for extended periods at the St. Louis gage (fig. 10A), the fluctuations in the average bed elevation (fig. 12A) closely resemble the fluctuations in average velocity (fig. 11A).

Unadjusted average bed elevations from measurements made at the Chester gage for all three discharge ranges and average bed elevations adjusted to remove part of the flow in Horse Island Chute for the $100,000 \mathrm{ft}^{3} / \mathrm{s}$ and $400,000 \mathrm{ft}^{3} / \mathrm{s}$ ranges are shown in figure $12 \mathrm{~B}$. Adjusting the average bed elevations to remove the flow in Horse Island Chute causes the data for the $400,000 \mathrm{ft}^{3} / \mathrm{s}$ range to plot among the data for the $100,000 \mathrm{ft}^{3} / \mathrm{s}$ range, whereas the average bed elevations for the $600,000 \mathrm{ft}^{3} / \mathrm{s}$ range plot approximately $12 \mathrm{ft}$ higher than the other two discharge ranges because the inclusion of flow on the right flood plain affects the average depth for the 600,000 $\mathrm{ft}^{3} / \mathrm{s}$ range. As with average velocities at the Chester gage (fig. 11B), average bed elevations for the $100,000 \mathrm{ft}^{3} / \mathrm{s}$ and $400,000 \mathrm{ft}^{3} / \mathrm{s}$ discharge ranges appear to be increasing slightly with time (fig. 12B). A notable exception is the last measurement in the $100,000 \mathrm{ft}^{3} / \mathrm{s}$ range, made on January 17,1996 , which has an average bed elevation similar to that seen in the early 1960s. This measurement was made after the 1993 and 1995 floods, and the measured area [32,500 square feet $\left.\left(\mathrm{ft}^{2}\right)\right]$ was substantially greater than measured areas from before the 1993 flood (for example, 26,700 $\mathrm{ft}^{2}$ measured on January 21, 1992 at a discharge of $99,200 \mathrm{ft}^{3} / \mathrm{s}$ ). The average bed elevation for the $600,000 \mathrm{ft}^{3} / \mathrm{s}$ range also appears to be increasing slightly with time, with the exception of the last measurement in the $600,000 \mathrm{ft}^{3} / \mathrm{s}$ range, which has an average bed elevation similar to those seen in 1973. This apparent increase in average bed elevation with time may contribute to the increase in rated gage height for a given discharge observed at the Chester gage after the completion of the Alton-Gale levee system in the mid-1960s (fig. 7B) that was not seen at the St. Louis gage (fig. 7A).

Part of the fluctuation of the average bed elevation is because it is a value calculated from several variables that fluctuate with time, namely stage, area, and top width, which occasionally combine in such a way that accentuates the fluctuations. Another part of the fluctuation of the average 

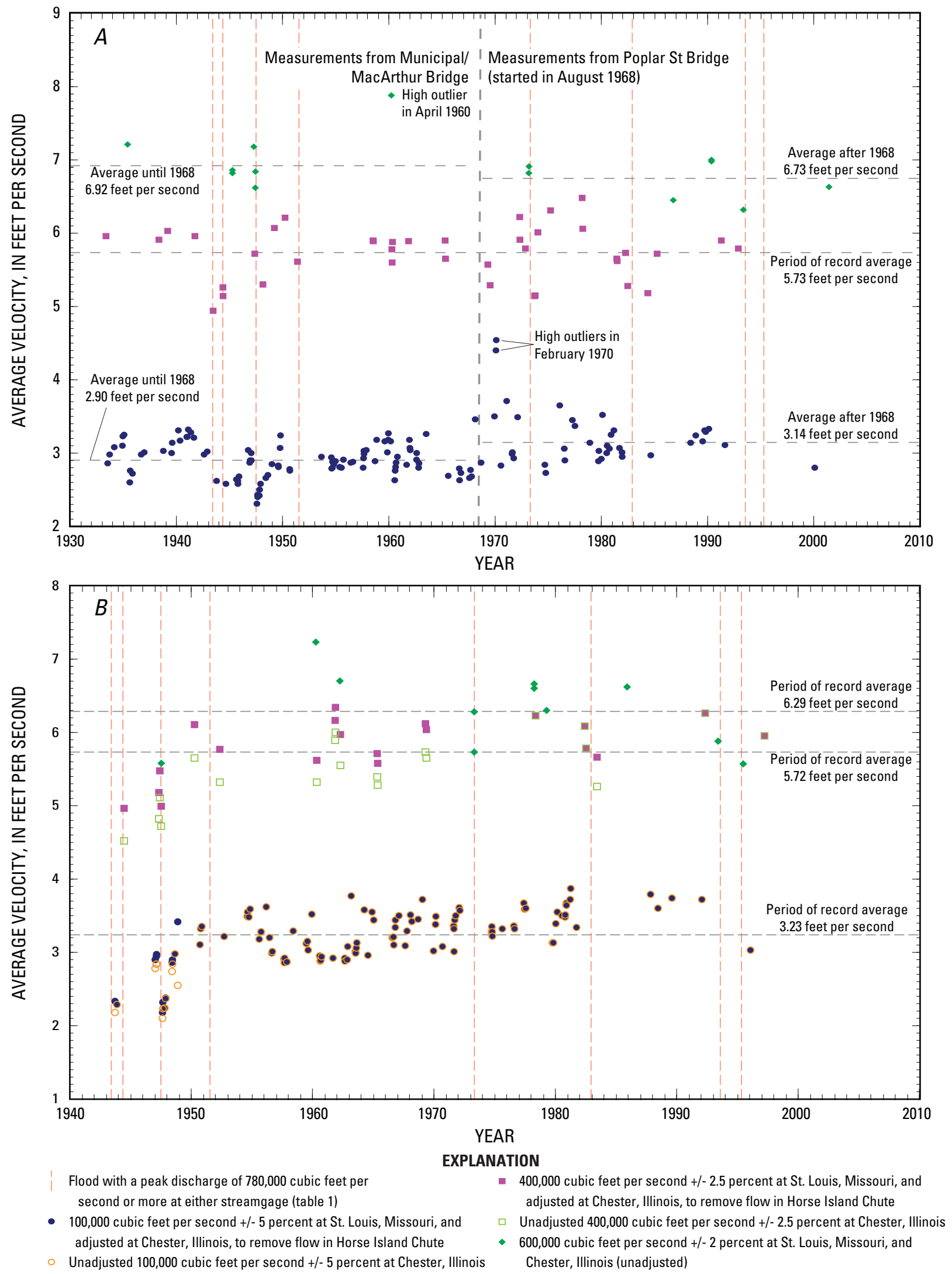

Figure 11. Average velocity for a given discharge range with time from measurements made at the streamgages at (A) St. Louis, Missouri, and (B) Chester, Illinois, on the Middle Mississippi River. 

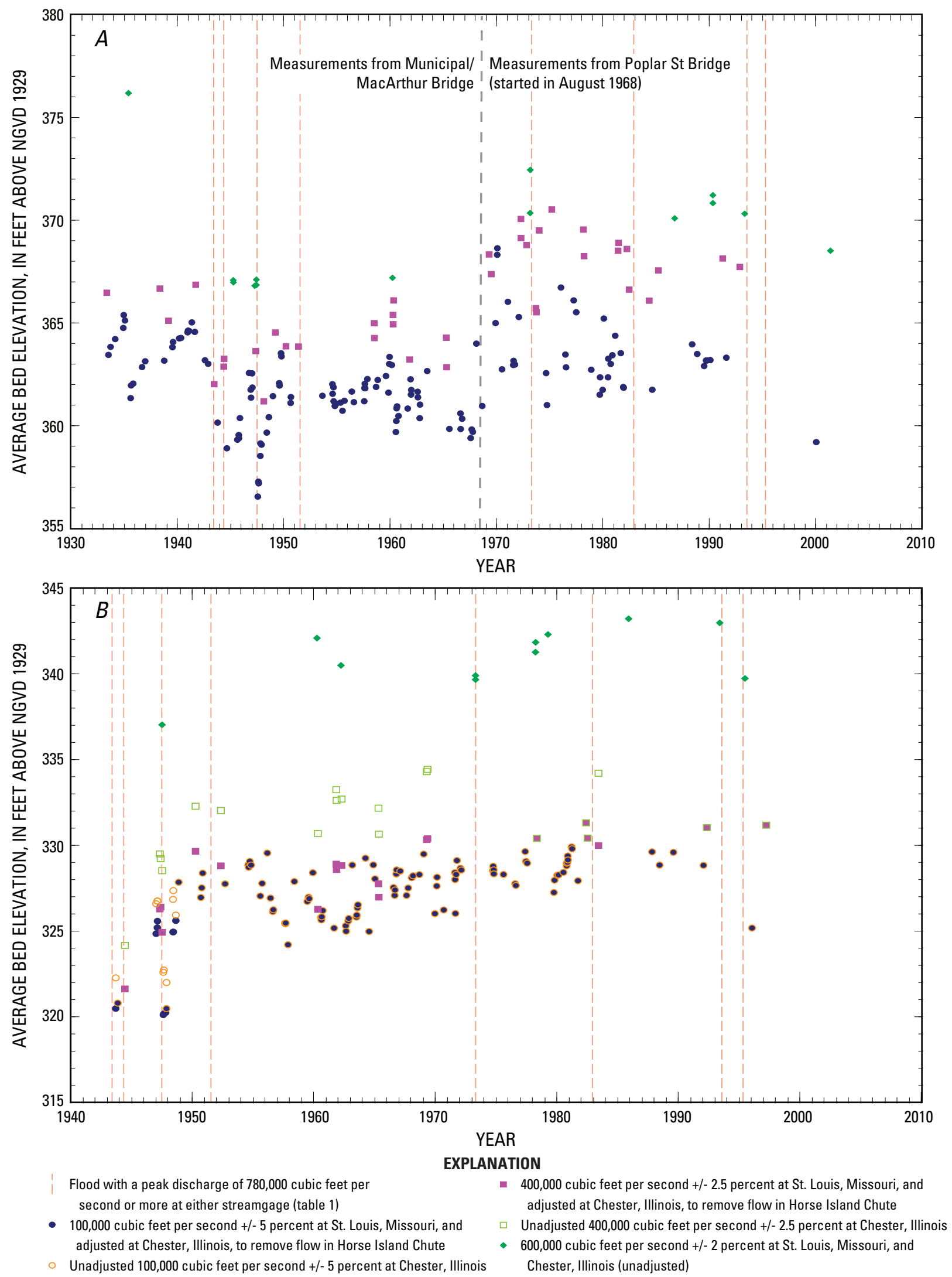

Figure 12. Average bed elevation for a given discharge range with time from measurements made at the streamgages at $(A)$ St. Louis, Missouri, and (B) Chester, Illinois, on the Middle Mississippi River. 
bed elevation is caused by the transition from in-channel to overbank flow. As mentioned above, when bank-overtopping occurs, often there is a substantial increase in measured top width with a relatively small change in area, which causes the average depth to be substantially less than for a similar in-channel flow. Removing measurements that are greater than bankfull eliminates these skewed average depths by limiting the analysis to in-channel flow only. After removing measurements with overbank flow (top width greater than bankfull at each streamgage, fig. 13), long-term changes in average bed elevation for in-channel flow with time become more evident when plotting every measurement without regard for specific discharge ranges. At the St. Louis gage, the average bed elevation for in-channel flow appears to have been steadily decreasing with time; the sudden change in 1968 marks when the measurement location moved to the Poplar Street Bridge, upstream from the Municipal/MacArthur Bridge. At the Chester gage, the average bed elevation for in-channel flow has fluctuated around an average value of $328.3 \mathrm{ft}$ between 1948 and 2000, but there was a steady increase in average bed elevations through 1993 after a decrease between 1951 and 1960. As noted previously in the "Top Widths from Measurements" section of this report, the few data available for the Chester gage before 1948 is a result of measurements including flow in Horse Island Chute, which caused the top width to be greater than bankfull. The average bed elevation for in-channel flows at the Chester gage lowered substantially after the floods of 1993 and 1995, but appeared to have rebounded to pre-flood levels by the late 1990s.

Whereas the dike field work upstream from the Chester gage in the early 1970s is speculated to have affected in-channel average velocities at the streamgage earlier in this report (fig. 11B), the relatively constant value of average bed elevation at the Chester gage is somewhat inconsistent with the general effect of dikes on the channel described earlier (Smith and Winkley, 1996). There is an abrupt lowering of the average bed elevation in 1969 that might be associated with the dike field work upstream from the Chester gage, but the channel appears to rebound by 1973 (fig. 13). Furthermore, as was seen with measured top width and average velocities, large floods appear to have an effect on the average bed elevation of in-channel flows at both streamgages (figs. 12 and 13). At the St. Louis and Chester gages, the average bed elevation for in-channel flows increases with time up to a large flood, and

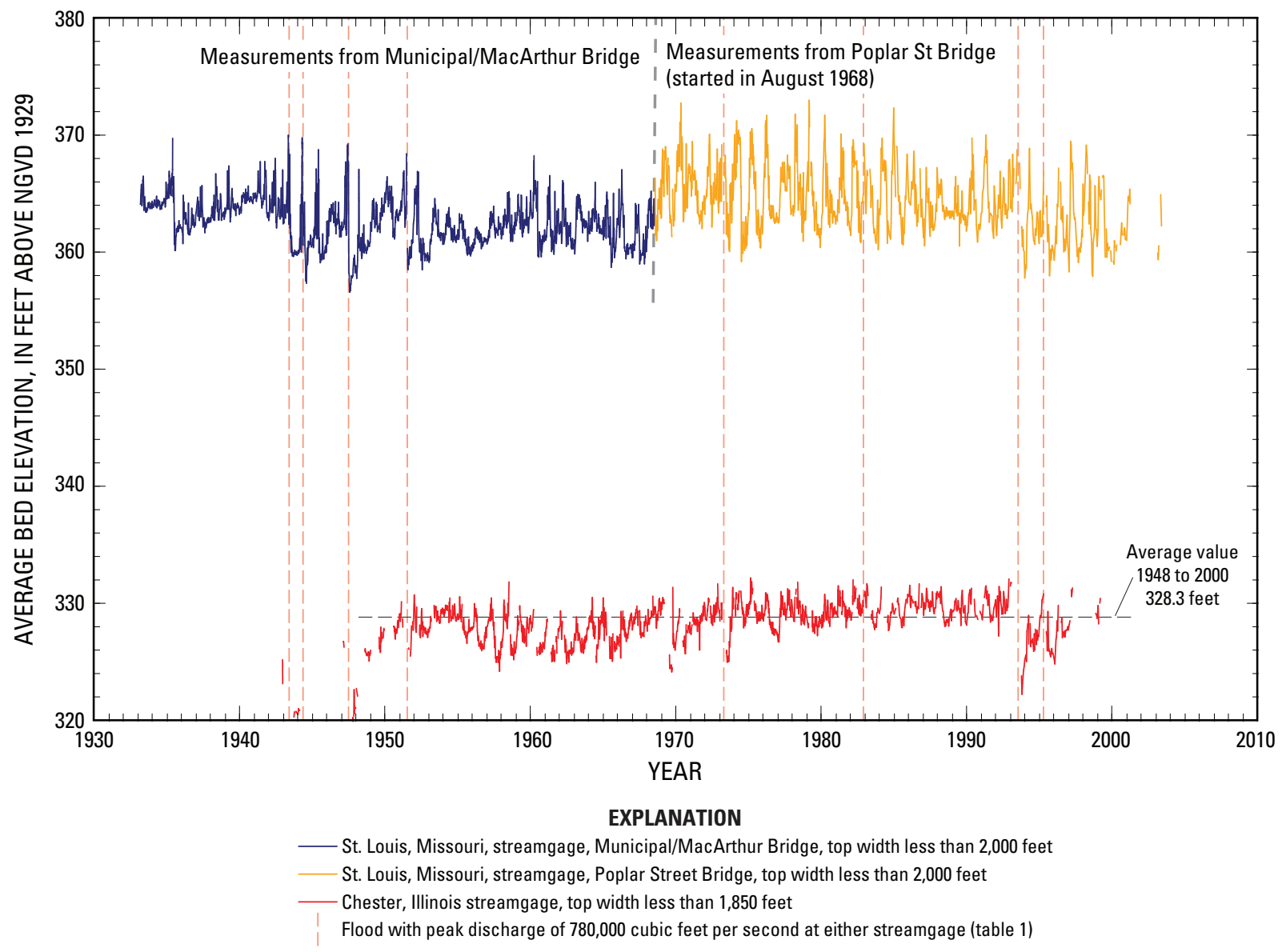

Figure 13. Average bed elevation with time for all measurements less than bankfull made at the streamgages at St. Louis, Missouri, and Chester, Illinois, on the Middle Mississippi River. 
lowers substantially immediately after the flood. Floods with greater than $780,000 \mathrm{ft}^{3} / \mathrm{s}$ at either streamgage are indicated on figures 12 and 13; however, other floods with lower discharges (table 1) appear to have the same effect as the larger floods, such as in 1935, 1945, 1948, 1960, 1961, 1969, 1970, and 1984 (figs 12 and 13).

The apparent decrease in stage with time for lower discharges (less than one-half bankfull) at the St. Louis streamgage (figs. $5 A$ and $7 A$ ) appears to be linked to the general lowering of the average bed elevation (fig. 12A). The top widths and average velocities from measurements have remained relatively constant at each of the measurement locations at the St. Louis streamgage (figs. $10 \mathrm{~A}$ and $11 \mathrm{~A}$ ), so the lowering of the average bed elevation with time results in a lowering of the stage with time for in-channel flows. The lowering of the average bed elevation with time likely is caused by a combination of dikes in the channel, which cause channel deepening in the thalweg of the channel at the end of the dikes, and a general decrease in sediment flux into the MMR, which results in less incoming sediment to replace outgoing sediment in the MMR.

The apparent increase in stage with time for increased discharges (greater than bankfull) at the St. Louis streamgage (figs. $5 A$ and $7 A$ ) appears to be linked to the completion of levees on the flood plains, particularly the Alton-Gale levee system completed in the mid-1960s. As levee projects have been completed through time, the measured and rated stages for a given discharge have increased (fig. 7A, table 3); however, after the completion of the Alton-Gale levee system in the mid-1960s, rated stages for a given discharge have decreased (fig. $7 A$, table 3). Because the top widths and average velocities from measurements for higher discharges are relatively constant with time (figs. $10 \mathrm{~A}$ and $11 \mathrm{~A}$ ), the general lowering of the average bed elevation with time (fig. 12A) results in a lowering of the rated stages for a given discharge with time at the St. Louis streamgage, even at discharges greater than flood stage.

The apparent decrease in stage with time for lower discharges is less pronounced at the Chester streamgage (figs. 5B and 7B) than at the St. Louis streamgage, because there is less lowering in average bed elevations with time at the Chester streamgage (fig. 12B). However, the average velocities from measurements increase slightly with time for in-channel flows (fig. 11B), and this offsets the relatively constant top widths and average bed elevations from measurements (figs. 10B and $12 B)$, resulting in a decrease in measured and rated stages with time for in-channel flows. The apparent increase in stage for a given discharge with time for increased discharges is more pronounced at the Chester streamgage (figs. 5B and 7B) than at the St. Louis streamgage, and likely is a combination of the completion of levees on the flood plains and the infilling of the inflow channel to the Horse Island Chute overflow channel with time (fig. 9), which has decreased the amount of flow carried by this overflow channel with time.

\section{Examination of Daily Stage and Discharge Data for Historic Period of Record}

Although the USGS began operating the St. Louis gage in 1933 and the Chester gage in 1942, the USACE has daily stage values going back to May 26, 1891, at the Chester gage, and daily stage and discharge records going back to January 1, 1861 , at the St. Louis gage. These historic stage records were examined for apparent changes with time outside of the period of USGS operation.

\section{Features of Historic Daily Values at St. Louis, Missouri, Streamgage before USGS Operation}

As mentioned in the "Description of Gages Used in Study" section above, streamgages directly measure stage, and discharge is computed using a rating curve, which is developed from discrete, direct discharge measurements at different stages. These measured values often scatter around the rating they describe (fig. 4). The daily values often display some amount of scatter around the rating as well (fig.14) because of the way the daily discharge is computed. Stage is measured at the St. Louis gage at 15-minute intervals, each called a "unit value of stage", and converted to a unit value of discharge by means of the rating curve in use at the time. The daily discharge is an average of all the individual unit values of discharge for that day, whereas the daily stage in this study is the stage at 8:00 AM. Generally, changes in stage during flood events is sufficiently slow on a large river like the Mississippi that correlating the average daily discharge with the stage at a specific time of day is not problematic; however, occasional outliers occur (fig. 14). These outliers usually occur on the rising limb of a flood hydrograph, when the stage value at 8:00 AM has not risen in response to a flood wave that occurs later in the day.

The relation between daily stage and daily discharge values from USACE archives at the St. Louis gage for the 66 years from 1861 to 1927 are shown in figure 15. During this time there were apparently five different ratings. The fact that the daily values for this time appear to fall along distinct rating lines (almost without exception) implies that these early daily values of discharge were obtained from the daily stage value through the rating in use at the time. According to publications of the Mississippi River Commission (1925), 511 individual discharge measurements were made on the MMR in the vicinity of the St. Louis gage from 1866 to 1923, ranging from $24,000 \mathrm{ft}^{3} / \mathrm{s}$ at a stage of $-0.1 \mathrm{ft}$ on December 9, 1897, to $1,146,000 \mathrm{ft}^{3} / \mathrm{s}$ at a stage of $35.2 \mathrm{ft}$ on May 21, 1892 (table 5). Several of the high measurements apparently were revised at a later date, based on data from the USGS peak flow file (table 1).

The first rating period shown in figure 15 is for a 20 -year span from 1861 to 1881 , and contains 7,670 individual daily values. During this time, 181 discharge measurements were 


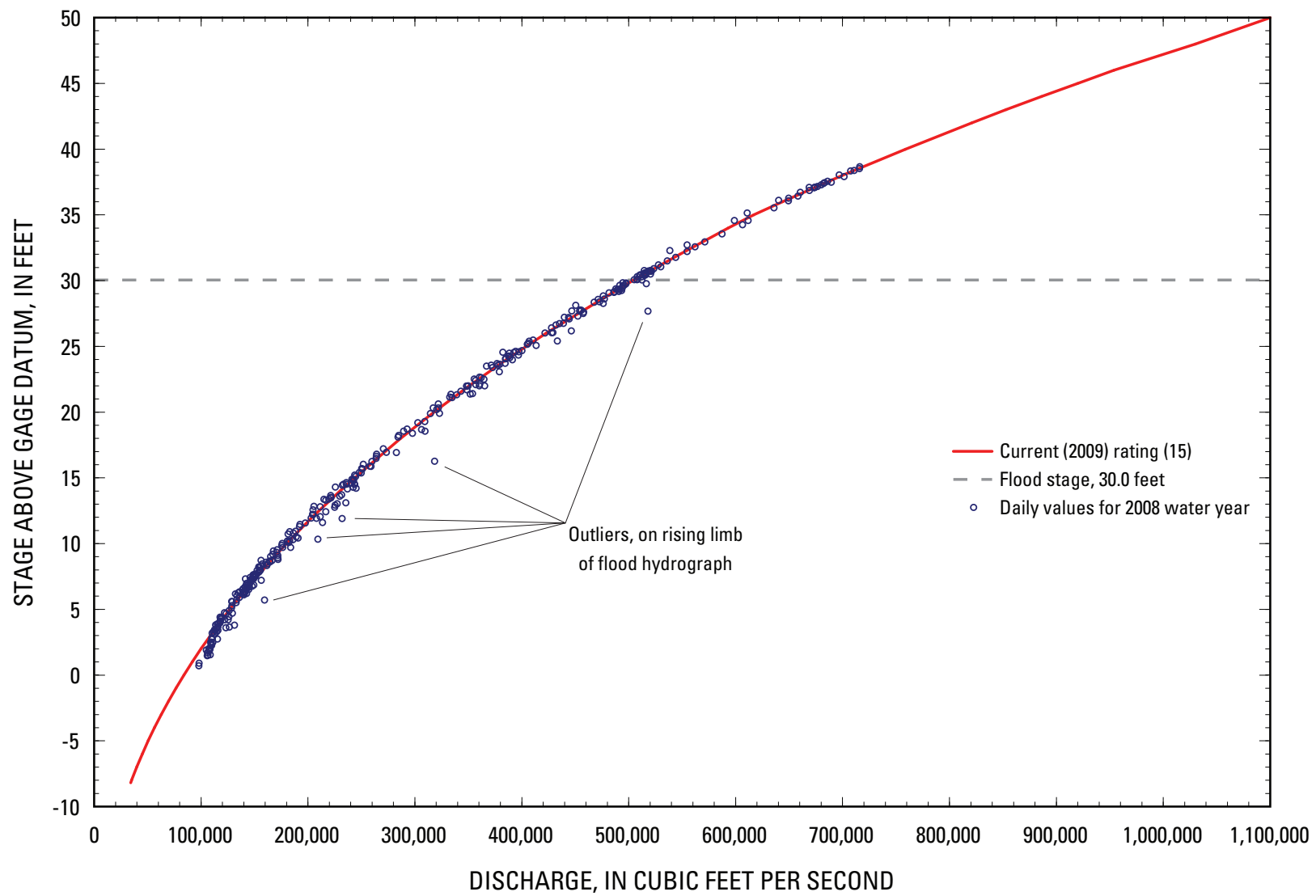

Figure 14. Stage and discharge from daily values for the 2008 water year (October 1, 2007 to September 30, 2008) at the streamgage at St. Louis, Missouri, on the Middle Mississippi River.

made, all but four of which were in 1880 and 1881 after the start of the Mississippi River Commission in 1879 (Mississippi River Commission, 1925; table 5). The measurements made in 1881 covered a broad range-from $45,000 \mathrm{ft}^{3} / \mathrm{s}$ to $896,000 \mathrm{ft}^{3} / \mathrm{s}$ - and effectively captured the flood that occurred that year (Mississippi River Commission, 1925), which was the only flood with a discharge of $780,000 \mathrm{ft}^{3} / \mathrm{s}$ or greater that occurred during the time covered by this first rating (table 1). The next longest rating period shown in figure 15 is for a 19-year span from 1896 to 1915 containing 7,045 individual daily values. During this time, 324 discharge measurements were made, ranging from 24,000 $\mathrm{ft}^{3} / \mathrm{s}$ to $611,000 \mathrm{ft}^{3} / \mathrm{s}$ (Mississippi River Commission, 1925). Most of these measurements (260) occurred from 1900 to 1904 . Also during this time, three floods with discharges of $780,000 \mathrm{ft}^{3} / \mathrm{s}$ or greater occurred (table 1). By comparison, since the USGS began operating the St. Louis gage in 1933, 12 years has been the longest time a rating was in effect (from 1976 to 1988, during a relative lowflow period at the St. Louis gage; table 1) because of changes to the controlling flow conditions of an alluvial river like the MMR (fig. $7 A$, table 3). It has been shown in the previous sections of this report that moderate and large floods have an effect on channel geometry and measurements with time, and the long times of the early historic ratings occasionally caused them to span several moderate and large flood events. Because of less frequent measurements before 1933, ratings were left in place much longer than after 1933, and may have been left in effect longer than applicable, lessening the accuracy of these daily discharge values compared to those after 1933.

Nevertheless, the historic daily values shown in figure 15 show changes of stage for a given discharge with time. The first three ratings shown in figure 15 , representing 1861 to 1915 , show a decrease in stage for a given discharge at lower discharges (approximately $1.5 \mathrm{ft}$ drop each time) with a slight increase in stage for a given discharge at higher discharges (fig. 15). They also appear to have been "fixed" or "pinned" at two points, which caused the part of the rating between the "pinned" points to curve upward as the lower end of the curve was lowered (fig. 15); these "pinned" points are at approximately $15 \mathrm{ft}$ of stage and $200,000 \mathrm{ft}^{3} / \mathrm{s}$ of discharge, and approximately $39.5 \mathrm{ft}$ of stage and $1,100,000 \mathrm{ft}^{3} / \mathrm{s}$ of discharge; however, the upper "pinned" point likely is the historic 


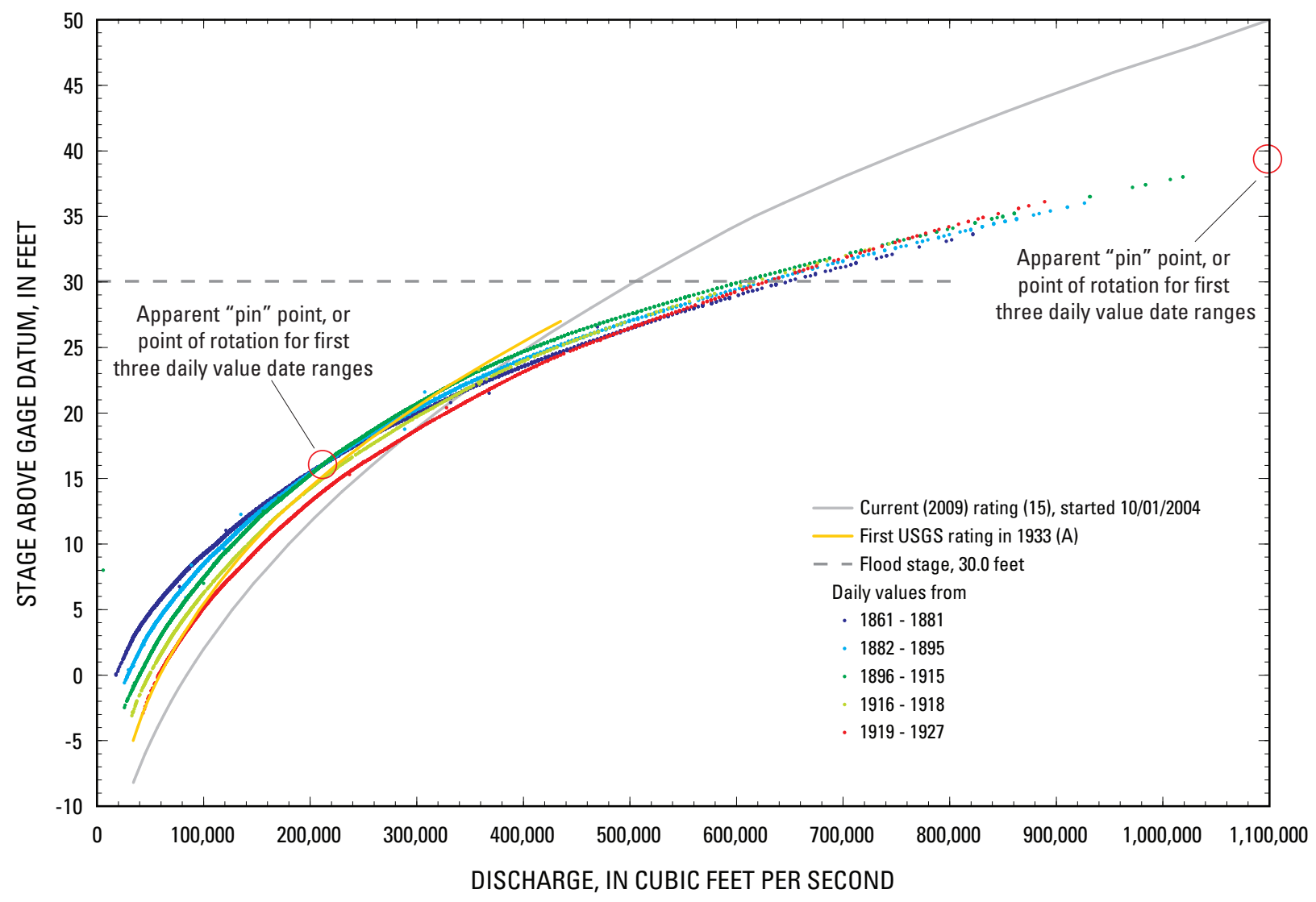

Figure 15. Stage and discharge from historic daily values from 1861 to 1927 at St. Louis, Missouri, on the Middle Mississippi River.

peak from the flood of 1844 . The flood of 1844 had a peak stage of $41.32 \mathrm{ft}$ at the St. Louis gage (table 1), and before 1998 was published by USGS as having a peak discharge of $1,300,000 \mathrm{ft}^{3} / \mathrm{s}$, which was estimated by the USACE from the 1903 flood at the Chester and Thebes gages (Gary Dyhouse, U.S. Army Corps of Engineers, written commun., 2009). The actual discharge of the 1844 event is unknown, but the published value officially was revised in 1998 in the USGS record to $1,000,000 \mathrm{ft}^{3} / \mathrm{s}$ as shown in table 1 , based on the results of physical and analytical model tests of this flood (Dyhouse, 1995; Dieckmann and Dyhouse, 1998) and further review by USACE (Melvin Baldus, U.S. Army Corps of Engineers, written commun., 1998).

The fourth rating period shown in figure 15 had the shortest duration, spanning 3 years from 1916 to 1918. This rating shows a continued lowering of the stage at a given discharge, but the pinned point at $15 \mathrm{ft}$ of stage and 200,000 $\mathrm{ft}^{3} / \mathrm{s}$ of discharge is removed, allowing a lowering of the stage for a given discharge throughout the range of discharges. The upper end of the rating for this period appears to rise slightly from the "pinned" point of the first three rating periods (fig. 15). The last rating period shown in figure 15, from 1919 to 1927, also shows a continued lowering of the stage at a given discharge throughout the range of discharges, with the upper end of the rating slightly higher than the "pinned" point of the first three rating periods.

The relation between daily stage values from the USACE and daily discharge from the USGS at the St. Louis gage for 1928 to 1933, after which the USGS began operating the streamgage, is shown in figure 16. Most of the daily values for 1928 and all of the daily values for 1930 through 1932 show the same characteristics as the daily values from 1861 to 1927, namely, the daily discharge values are directly related to the daily stage by means of the rating in use at the time, even though the rating appeared to change each year (fig. 16). Although part of the daily value data in 1928 and 1929 appear to be closely tied to a rating, these years display a substantial amount of scatter, which does not follow the curve of a "rating line" seen in all of the other years (fig. 16). In 1928, the most substantial outliers not on a "rating line" primarily occur in early January at the low end of the rating for that year, and represent water backing up from an ice jam downstream from the St. Louis gage that resulted in higher stages at the gage without an increase in discharge (Mark Fuchs, National Oceanic and Atmospheric Administration, written commun., 2009). From September 1928 and throughout 1929, outliers not on a "rating line" occur primarily at discharge values greater than $200,000 \mathrm{ft}^{3} / \mathrm{s}$, and appear to represent spikes in the discharge values, although no explanation was found for 
Table 5. Summary of discharge measurements recorded by the Mississippi River Commission near St. Louis, Missouri, on the Middle Mississippi River from 1861 to 1923 (from Mississippi River Commission, 1925).

$\left[\mathrm{ft}\right.$, feet; $\mathrm{ft}^{3} / \mathrm{s}$, cubic feet per second]

\begin{tabular}{|c|c|c|c|c|c|c|c|}
\hline \multirow[b]{2}{*}{ Year } & \multirow[b]{2}{*}{$\begin{array}{c}\text { Number of } \\
\text { measure- } \\
\text { ments }\end{array}$} & \multicolumn{2}{|c|}{ Date range } & \multicolumn{2}{|c|}{ Stage range } & \multicolumn{2}{|c|}{ Discharge range } \\
\hline & & First & Last & $\begin{array}{c}\text { Lowest } \\
\text { value } \\
\text { (ft) }\end{array}$ & $\begin{array}{c}\text { Highest } \\
\text { value } \\
\text { (ft) }\end{array}$ & $\begin{array}{c}\text { Lowest value } \\
\left(\mathrm{ft}^{3} / \mathrm{s}\right)\end{array}$ & $\begin{array}{l}\text { Highest value } \\
\qquad\left(\mathrm{ft}^{3} / \mathrm{s}\right)\end{array}$ \\
\hline 1866 & 2 & Aug 9 & Oct 24 & 12.7 & 19.7 & 211,000 & 384,000 \\
\hline 1872 & 1 & May & May & 20.4 & 20.4 & 315,000 & 315,000 \\
\hline 1873 & 1 & May 16-17 & May 16-17 & 21.8 & 21.8 & 369,000 & 369,000 \\
\hline 1880 & 12 & Oct 14 & Dec 14 & 5.4 & 10.0 & 51,000 & 107,000 \\
\hline 1881 & 165 & Jan 12 & Nov 4 & 7.6 & 33.6 & 45,000 & $896,000^{\mathrm{a}}$ \\
\hline 1892 & 2 & May 20 & May 21 & 35.2 & 35.7 & $1,043,000^{\mathrm{a}}$ & $1,146,000^{\mathrm{a}}$ \\
\hline 1895 & 1 & Oct 25 & Oct 25 & 3.0 & 3.0 & 48,000 & 48,000 \\
\hline 1896 & 2 & Dec 16 & Dec 17 & 5.5 & 6.0 & 67,000 & 72,000 \\
\hline 1897 & 3 & Sep 20 & Dec 9 & -.1 & 4.0 & 24,000 & 68,000 \\
\hline 1898 & 1 & Dec 23 & Dec 23 & 6.3 & 6.3 & 96,000 & 96,000 \\
\hline 1899 & 3 & Jan 12 & Oct 7 & 4.0 & 13.3 & 61,000 & 178,000 \\
\hline 1900 & 115 & Feb 3 & Dec 27 & 0.0 & 23.2 & 35,000 & $408,000^{\mathrm{a}}$ \\
\hline 1901 & 19 & Jan 7 & Nov 8 & .6 & 4.8 & 40,000 & 73,000 \\
\hline 1902 & 3 & Jan 16 & Jul 18-19 & 1.3 & 26.4 & 44,000 & 428,000 \\
\hline 1903 & 53 & Apr 24 & Dec 23 & 2.3 & 31.3 & 51,000 & 611,000 \\
\hline 1904 & 70 & Mar 9 & Dec 22 & .2 & 25.2 & 39,000 & 425,000 \\
\hline 1905 & 1 & Jan 3 & Jan 3 & 1.5 & 1.5 & 54,000 & 54,000 \\
\hline 1909 & 14 & Jan 5 & Jul 20 & 2.70 & 35.25 & 62,000 & $851,000^{\mathrm{a}}$ \\
\hline 1910 & 9 & Aug 16 & Dec 31 & -1.42 & 3.82 & 33,000 & 70,000 \\
\hline 1912 & 2 & Apr 6 & Dec 30 & 2.20 & 30.72 & 56,000 & $711,000^{\mathrm{a}}$ \\
\hline 1913 & 4 & Jan 16 & Jan 16 & -.04 & -.04 & 39,000 & 39,000 \\
\hline 1914 & 9 & Jan 7 & Feb 2 & -.1 & 3.7 & 44,000 & 71,000 \\
\hline 1915 & 19 & Jan 13 & Jul 3 & 2.40 & 31.55 & 65,000 & $734,000^{\mathrm{a}}$ \\
\hline 1919 & 1 & Sep 20 & Sep 20 & 1.6 & 1.6 & 65,000 & 65,000 \\
\hline 1922 & 3 & Apr 20 & Nov 27 & 3.3 & 33.9 & 54,000 & 762,000 \\
\hline
\end{tabular}

${ }^{a}$ Discharge apparently revised at some later date, based on data in U.S. Geological Survey peak flow file, table 1.

the spikes. The data for 1929 essentially fill the area between the 1919 to 1927 rating and the first USGS rating, "A" (which, when extended, appears to tie into the current (2009) rating, "15"; figs. 15 and 16). Although the ratings used since the USGS began operation vary with time (fig. $6 A$ ), the range of differences in the ratings for nearly 80 years of data has been narrower than for the 1 year of data in 1929.

Starting in 1933, the daily values began to demonstrate the variability around the first USGS rating typical of daily values computed from unit values as seen in figure 14, plotting in the general vicinity of the rating (fig. 16). Disregarding the apparently erroneous discharge data from September 1928 to
December 1929, there appears to be an abrupt change in the upper end of the ratings used before 1933 (figs. 15 and 16) and the upper end of the first USGS rating, "A" (fig. 16). This change likely represents the change in measurement methods to the Price AA current meter. Stevens (1979) indicated that discharge measurements made with instruments in use before the advent of the Price AA current meter (such as single and double floats and rod floats) over-estimated the discharge by 5 percent or more compared to the Price AA current meter, with more than 40 percent of the comparison measurements being more than 10 percent different. Other simultaneous measurements made by the USACE and USGS in 1935, 1939, 1944, 
1947, and 1948 indicated the USACE consistently measured discharges larger than those obtained by the USGS by as much as 17 percent (Gary Dyhouse, U.S. Army Corps of Engineers, written commun., 2009).

The physical tests using the Mississippi Basin Model at the USACE Waterways Experiment Station in Clinton, Mississippi, discussed in Dyhouse (1995) also exposed this tendency to over-estimate flood flows in the historic record, and resulted in some revision of the historic record. The actual discharges of the 1844 and 1903 events are unknown at the St. Louis gage, and were estimated from measurements of the 1903 flood at the Chester and Thebes gages (Gary Dyhouse, U.S. Army Corps of Engineers, written commun., 2009). According to Dyhouse (1995), tests with the Mississippi Basin Model under flood plain land-use conditions appropriate to 1844 showed a reasonable match to high water marks for the flood of 1844 at a discharge of $870,000 \mathrm{ft}^{3} / \mathrm{s}$, which is 33 percent less than the unrevised discharge published by USGS before 1998 of $1,300,000 \mathrm{ft}^{3} / \mathrm{s}$. The modeled value of $870,000 \mathrm{ft}^{3} / \mathrm{s}$ was revised by the USACE to a conservative upper limit of $1,000,000 \mathrm{ft}^{3} / \mathrm{s}$ as shown in table 1 based on additional analytical model tests (Dieckmann and Dyhouse, 1998). The flood of 1903 also was examined in the physical model tests, and showed a reasonable match to high water marks at a discharge of 780,000 $\mathrm{ft}^{3} / \mathrm{s}$ (Dyhouse, 1995), which is 24 percent less than the published discharge of $1,020,000 \mathrm{ft}^{3} / \mathrm{s}$. Ultimately, the peak discharge of the 1903 flood was not revised in the USGS record (table 1), even though it is shown as greater than the peak discharge from the flood of 1844 (which had a $3.32 \mathrm{ft}$ higher stage) because of the implications for the entire historic record before 1933 (Gary Wilson, U.S. Geological Survey, oral commun., 2009); however, these findings for historic flood discharges indicate the uncertainty of the published discharge data for the St. Louis gage before 1933.

If the lower peak discharges from Dyhouse (1995) were used for the 1844 and 1903 floods, the entire historic record before USGS began streamgage operation in 1933 would need to be revised; the upper "pinned" point apparent in figure 15 would move to a stage of $41.32 \mathrm{ft}$ and a discharge of 870,000 $\mathrm{ft}^{3} / \mathrm{s}$, which would cause all of the daily discharge values from before 1933 to shift to the left; however, an adjustment of this sort likely would cause the historic data to be more in the range of the various USGS ratings in use in the 1930s (table 3; figs. $6 A$ and $7 A$ ). A sample set of adjusted daily data from 1919 to 1927 are shown in figure 17 with a 24 percent progressive reduction in discharge (no reduction at the minimum stage for the range and a 24 percent reduction at the maximum stage of the range, and proportional between the minimum and maximum stages, based on stage), and these data plot near the first USGS rating "A" and appear to extend to the adjusted peak for the 1903 flood suggested by Dyhouse (1995).

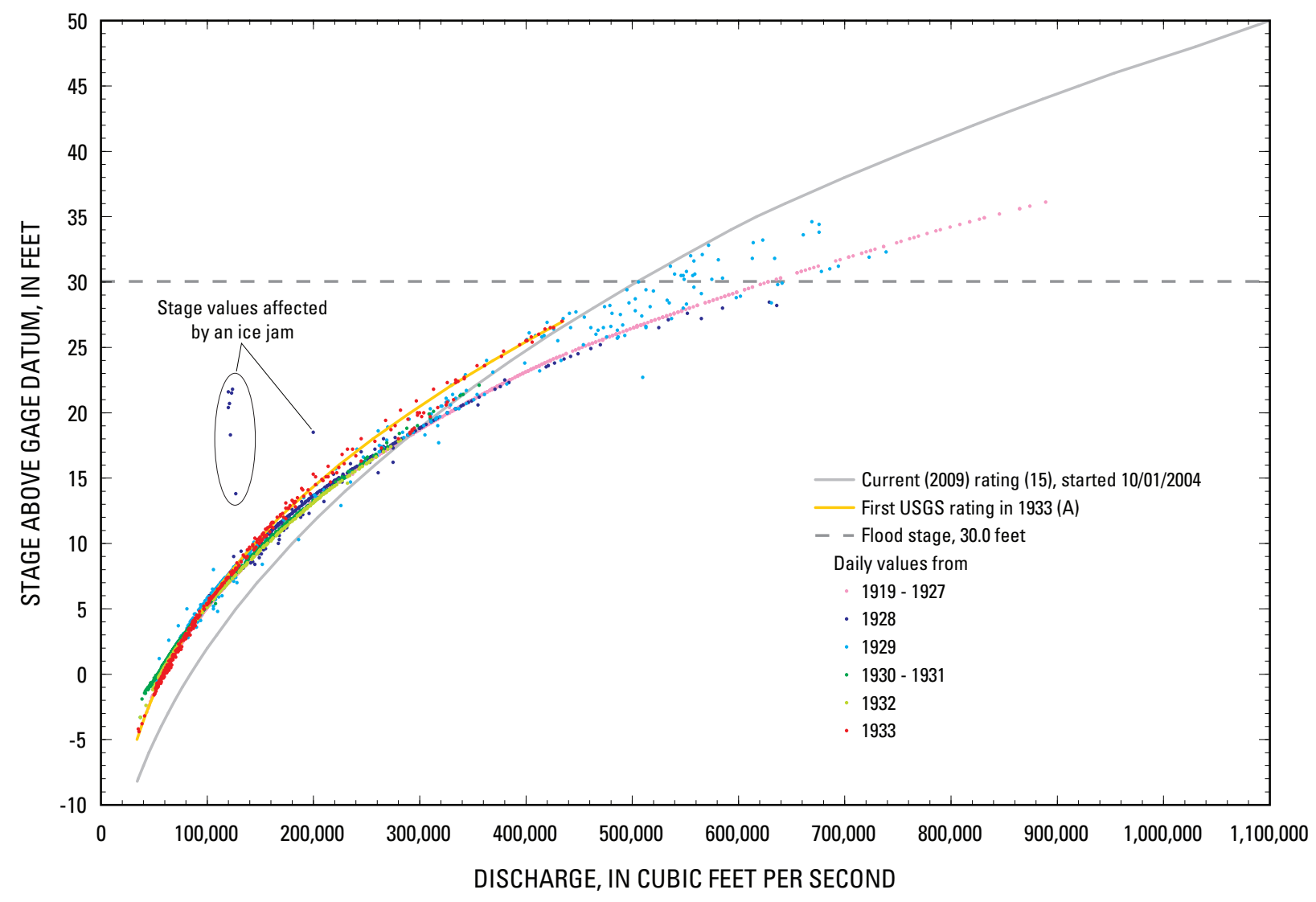

Figure 16. Stage and discharge from historic daily values from 1919 to 1933 at St. Louis, Missouri, on the Middle Mississippi River. 


\section{Changes in Water-Surface Elevation Difference Between Gages with Time}

Daily discharge values were not available for the Chester gage before USGS operation, so a similar assessment of the historic daily values could not be made at that streamgage beyond what has already been shown; however, daily stage data are available to 1891 from the USACE, so additional analysis of stage values at the two streamgages could be done. For example, figure 18 shows the difference in water-surface elevation between the St. Louis and Chester gages through time. Water-surface elevation is computed as the daily stage value added to the gage datum. There is a lag of approximately 1 day between peaks at the St. Louis and Chester gages, which means that the peak of a flood wave observed at the St. Louis gage generally is observed at the Chester gage the next day; therefore, the difference shown in figure 18 represents the daily stage value for a given day at the Chester gage subtracted from the stage value at the St. Louis gage from the previous day.

The difference in water-surface elevation fluctuates cyclically, likely following an annual cycle based on seasonal effects (Fenwick, 1969; Simon, Li and Associates, 1985), but the annual mean value indicates the general trend of the difference (fig. 18, table 6). The difference in water-surface elevation between the St. Louis and Chester gages generally decreased from 1891 until the mid 1920s, with a brief but substantial increase from 1924 and 1925, followed by an abrupt decrease from 1926 to 1930 (fig. 18, table 6). The general decrease of the difference ends in the early 1930s. The average value of the mean annual difference from 1940 to 2008 is $37.05 \mathrm{ft}$ (fig. 18), and the mean annual difference varies from the average value by approximately 1 foot or less from the early 1930s to 2008 (table 6). From 1941 to 1954, the mean annual difference was above the average, and from 1993 to 2008, the mean annual difference has been below the average from 1940 to 2008 (fig. 18, table 6). There is a general decrease in the difference from 1976 to 2008 (fig. 18, table 6)

Several of the abrupt changes observed in the mean annual difference in water-surface elevation appear to be caused by large flood events (4 percent or less annual exceedance probability, or 25-year or greater recurrence, fig. 18), but not all of the abrupt changes can be traced to large floods. An abrupt change in 1940 (fig. 18) appears to be caused by an unusually low annual peak flow compared to the surrounding years (table 1). Other changes may be the result of medium floods with higher annual exceedance probabilities (lower recurrences) such as 1915 through 1917 (fig. 18, table 1), or longer periods of low flow such as 1953 through 1960 (fig. 18, table 1). The general decrease in the difference from 1976 to

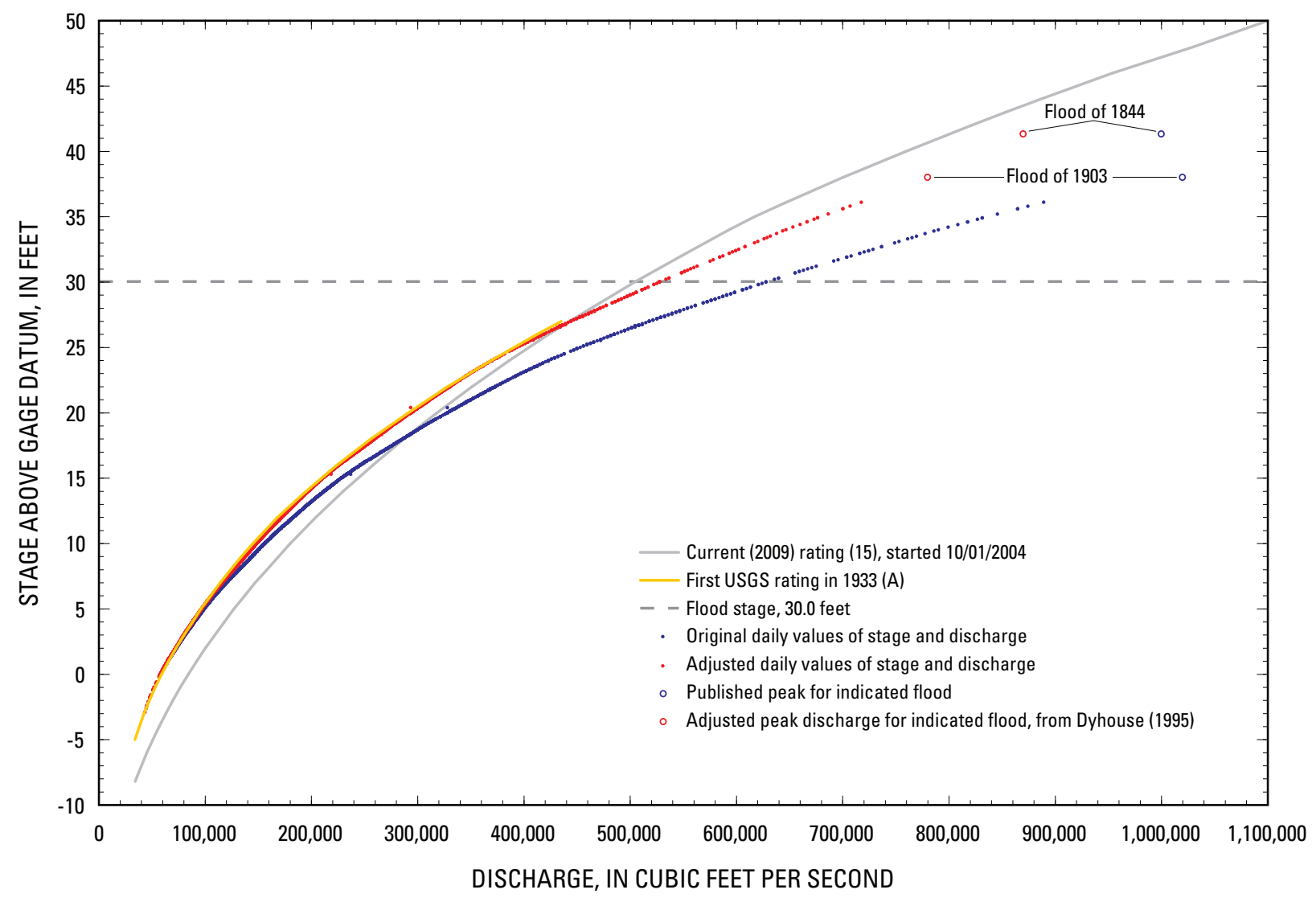

Figure 17. Original and adjusted daily values of stage and discharge from 1919 to 1927 at St. Louis, Missouri, on the Middle Mississippi River. 
2008 may be the result of diminished suspended sediment in the MMR for that time; Horowitz (2006) determined suspended sediment concentrations to be diminished by 10 to 36 percent after the 1993 flood because of the removal of "stored" bed sediment or readily erodible flood plain deposits; the same may have been true after the 1973 flood.

The steady decrease in water-surface elevation difference between the St. Louis and Chester gages before the early 1930s (fig. 18) likely is the result of the MMR adjusting to channel changes from before 1890, such as the Kaskaskia cutoff that occurred in 1881. The Mississippi River established a new course through the Kaskaskia Peninsula during the flood of 1881 (Brauer and others, 2005; GreatRiverRoad, 2009; table 1), shortening the channel by approximately $9 \mathrm{mi}$ just upstream from the Chester gage. Biedenharn and Watson (1997) noted in their study of the LMR that it can take years to decades for the river to stabilize after a cutoff shortens the channel length, and the temporal response of a gage to the effects of a cutoff will depend on the proximity of the gage to the cutoff. Because the Kaskaskia cutoff occurred just upstream from the Chester gage, it may well have taken 40 years for the effects of the cutoff to be fully manifested at the St. Louis gage.

To broaden the examination of these apparent changes with time, the daily values of stage from the USACE at the continuous stage-only gage at Cape Girardeau were included. The Thebes gage was considered for this analysis, but daily values of stage at the Thebes gage only go back to 1932 when the USGS began operation there, whereas at the Cape Girardeau gage, daily values of stage go back as far as May 3,1896 . The difference in water-surface elevation between daily values at the St. Louis, Chester, and Cape Girardeau gages through time are shown in figure 19. There is a lag of approximately one-half to three-quarters of a day between peaks at the Chester and Cape Girardeau gages, which means that the peak of a flood wave observed at the Chester gage could be observed at the Cape Girardeau gage the same day or the next day, depending on the timing of the peak. However, a 1-day lag between the Chester and Cape Girardeau gages was used in this analysis, so the difference between the Chester and Cape Girardeau gages shown in figure 19B represents the daily stage value for a given day at the Cape Girardeau gage

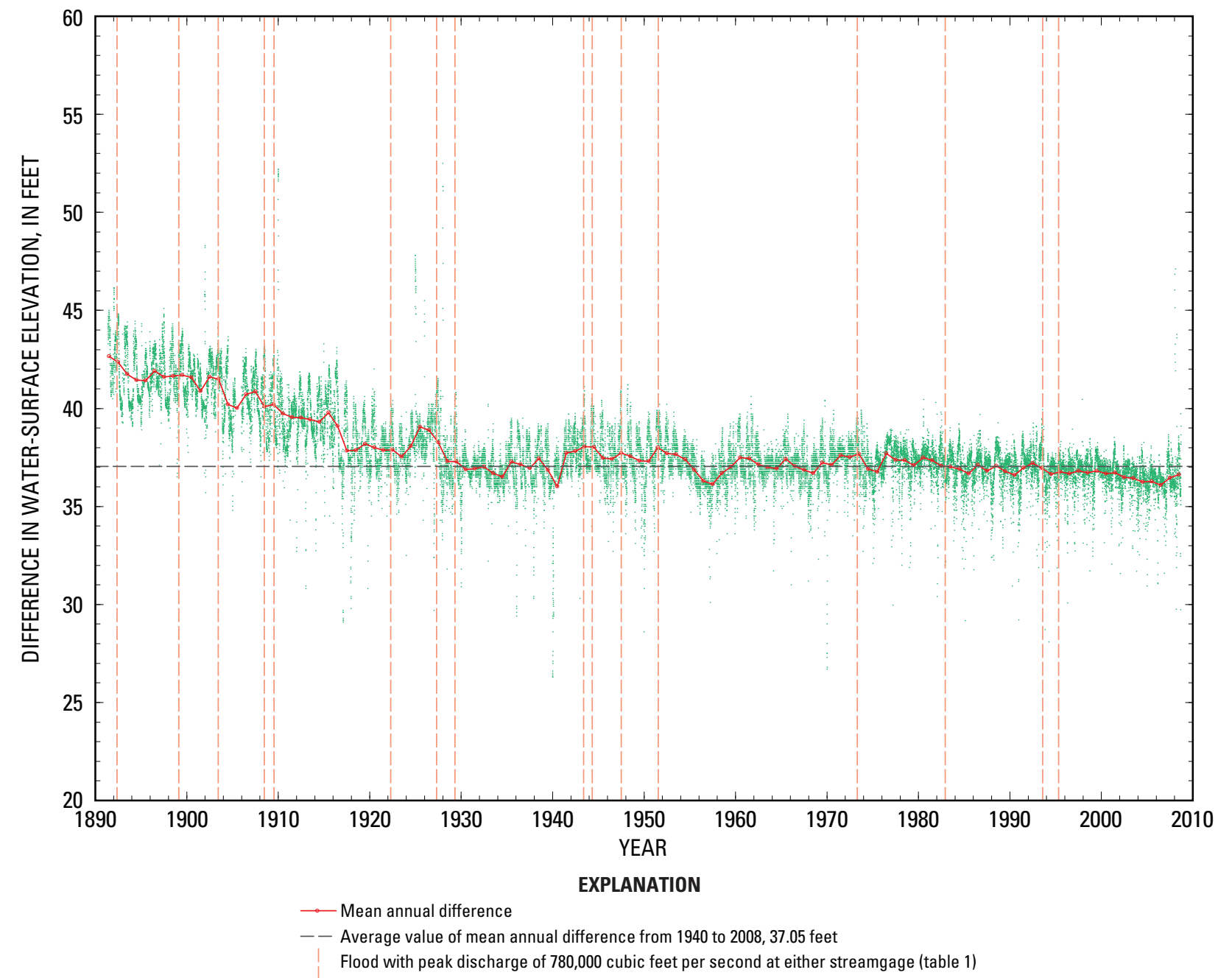

Figure 18. Difference in daily water-surface elevation between the streamgages at St. Louis, Missouri, and Chester, Illinois, on the Middle Mississippi River with time. 


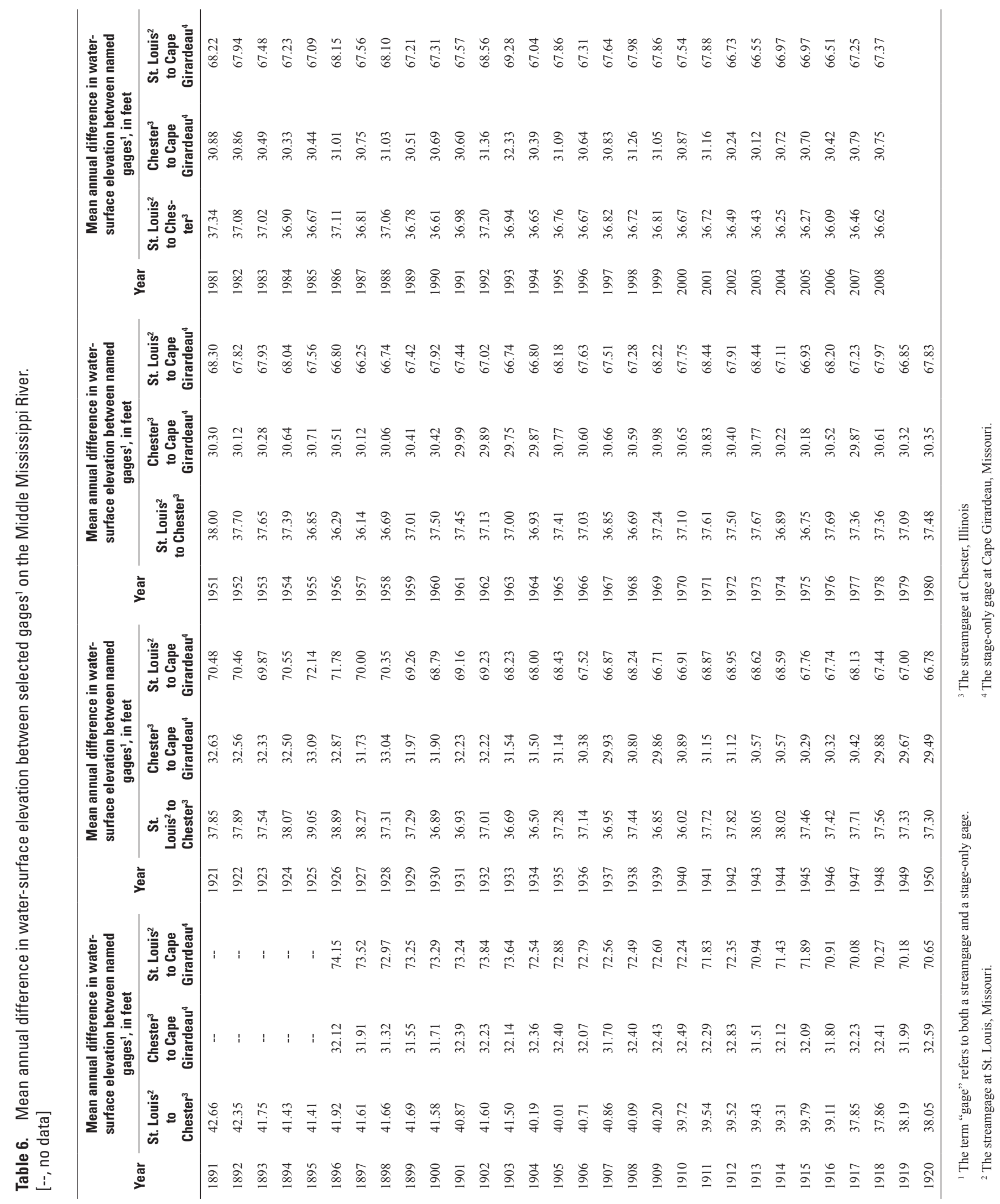






Figure 19. Difference in daily water-surface elevation between the gages at St. Louis, Missouri, Chester, Illinois, and Cape Girardeau, Missouri, on the Middle Mississippi River with time. 
subtracted from the stage value at the Chester gage from the previous day. Similarly, the difference between the St. Louis and Cape Girardeau gages shown in figure 19C represents the daily stage value for a given day at the Cape Girardeau gage subtracted from the stage value 2 days prior at the St. Louis gage.

The difference in water-surface elevations between the Chester and Cape Girardeau gages (fig. 19B) from 1896 to 1930 is essentially flat at $32.22 \mathrm{ft}$, and the mean annual difference varies from this average value by less than 1 foot during that time (table 6). The average value of the mean annual difference from 1940 to 2008 is $30.55 \mathrm{ft}$ (fig. 19B), and the mean annual difference varies from the average value by approximately 1 foot or less from 1940 to 2008, with the exception of 1993, which varies from the average value by 1.8 $\mathrm{ft}$ (table 6). As is seen between the St. Louis and Chester gages (fig. 19A), there are a few abrupt fluctuations in the difference between the Chester and Cape Girardeau gages (fig. 19B) that are related to medium and large floods on the MMR, or longer periods of low flow such as in the 1950s. The change in the difference between 1930 and 1940 appears to be correlated to the dike construction throughout the MMR from 1926 to 1942 (fig. 2), as there were no medium or large floods from 1930 to 1940 to cause the change (table 1). However, from 1933 to 1942 also was the time when several natural and man-made cutoffs were made on the LMR (Biedenharn and Watson, 1997), and the change in the difference between the Chester and Cape Girardeau gages may be a function of the MMR adjusting to those changes on the LMR. The lack of variation in the difference from 1896 to 1930 between the Chester and Cape Girardeau gages (fig. 19B) implies that the cause of the decreasing difference between the St. Louis and Chester gages from 1891 to 1930 (fig. 19A) occurred on the reach between the St. Louis and Chester gages, which lends further credence to the hypothesis that the cause of the decreasing difference was the Kaskaskia cutoff.

Unlike the steady difference between the Chester and Cape Girardeau gages (fig. 19B), the difference in watersurface elevations between the St. Louis and Cape Girardeau gages (fig. 19C) displays some of the same fluctuations with time as seen between the St. Louis and Chester gages (fig. $19 A$ ), although the magnitude of fluctuations in the difference between the St. Louis and Cape Girardeau gages is somewhat greater than between the St. Louis and Chester gages. The average value of the mean annual difference from 1940 to 2008 is $67.60 \mathrm{ft}$ (fig. 19C), and the mean annual difference varies from the average value by $1.4 \mathrm{ft}$ or less from 1940 to December 2008, with the exception of 1993, which varies from the average value by $1.7 \mathrm{ft}$ (table 6). The steady decrease in the difference observed from 1891 to 1930 between the St. Louis and Chester gages (fig. 19A) is reflected in the difference between the St. Louis and Cape Girardeau gages (fig. $19 C$ ), further supporting the hypothesis that the cause of the decrease was between the St. Louis and Chester gages, such as the Kaskaskia cutoff.

\section{Examination of Channel Cross-Section Data from Measurements}

When combined with the water-surface elevation, the transverse incremental depth and width information from the measurements at the St. Louis and Chester gages provide a cross section of the measurement section for each measurement. These cross sections extracted from the measurements can be examined through time, provided the location of the measurement is consistent. Although boat measurements are not made at the same location each time, the Municipal/ MacArthur and Poplar Street Bridges at the St. Louis gage and the Chester Bridge at the Chester gage were consistent measurement locations, and measurements at each location through time can be compared with others at the same location (Rantz and others, 1982). Cross sections from measurements for the following three discharge ranges from table 2 were extracted and examined at each measurement location: $100,000 \mathrm{ft}^{3} / \mathrm{s}+/-5$ percent, $400,000 \mathrm{ft}^{3} / \mathrm{s}+/-2.5$ percent, and $600,000 \mathrm{ft}^{3} / \mathrm{s}+/-2$ percent. As stated previously, these discharge ranges were chosen because they have a reasonably substantial number of measurements at both streamgages (table 2), and represent flow conditions that likely would be affected by dikes $\left[100,000 \mathrm{ft}^{3} / \mathrm{s}\right.$ is between low flow and one-half bankfull (figs. 5 and 7)], moderate flood conditions that generally are contained within the main channel $[400,000$ $\mathrm{ft}^{3} / \mathrm{s}$ occurs at stages less than flood stage for both streamgages (figs. 5 and 7)], and larger flood conditions that are not contained within the main channel $\left[600,000 \mathrm{ft}^{3} / \mathrm{s}\right.$ occurs at stages greater than flood stage at both streamgages (figs. 5 and 7)]. In addition, the cross sections for all the measurements made during the 1993 flood were extracted and examined at the Poplar Street Bridge at the St. Louis gage, and at the Chester Bridge at the Chester gage.

In the following sections, many plots contain numerous cross sections, particularly for the $100,000 \mathrm{ft}^{3} / \mathrm{s}+/-5$ percent discharge range. Rather than identifying all of the cross sections in a discharge range, the cross sections from the first and last measurements are specifically labeled, and the cross sections that are the highest or lowest in a particular part of the channel for the given discharge range are labeled. The cross sections that are considered the lowest in a part of the channel generally were chosen, ignoring the local scour effects from piers and at the toe of banks.

\section{St. Louis, Missouri}

As mentioned previously in this report, the measurements were made from the Municipal/MacArthur Bridge until August 1968, when use of the monorail on the Poplar Street Bridge began. Each of these measurement locations must be considered separately. 


\section{Municipal/MacArthur Bridge}

Cross sections extracted from 95 measurements in the $100,000 \mathrm{ft}^{3} / \mathrm{s}$ range at the Municipal/MacArthur Bridge are shown in figure 20. In the part of the channel between the Illinois bank and the left main channel pier, the cross section from the measurement on September 10, 1935, is the highest of the cross sections in this range, and the cross section from the measurement on November 2, 1960, is the lowest of the sections in this range (ignoring the local scour at the base of the left bank and at the pier, fig. 20). In the part of the channel between the main channel piers, the cross sections from the measurements on February 12, 1935, and February 27, 1968, are the highest, and the cross sections from the measurements on June 14, 1948, and August 1, 1960, are the lowest (ignoring the local scour at the piers, fig. 20). In the part of the channel between the right main channel pier and the Missouri bank, the cross section from the measurement on January 15, 1962, is the highest, and the cross section from the measurement on June 14, 1948, is the lowest (ignoring the local scour at the base of the right bank and at the pier, fig. 20).

Whereas the cross sections from the first and last measurements (July 26, 1933, and September 16, 1968, respectively) are similar, the fluctuations between the highest and lowest of all the sections in this discharge range are as much as $17 \mathrm{ft}$ (fig. 20). The maximum fluctuation of the average bed elevation is approximately $8.8 \mathrm{ft}$ for this discharge range (fig. $12 A)$. There are several measurements in this discharge range that have similar or exact discharges, and yet demonstrate the variability of stages with time as a result of temperature or seasonal variations, rising or falling stage, or error in measurement, as presented in the "Various Factors Affecting Stage and Discharge at Streamgages" section above.

Similarly, cross sections extracted from 20 non-boat measurements in the $400,000 \mathrm{ft}^{3} / \mathrm{s}$ range fluctuated as much as $16 \mathrm{ft}$ in some locations (fig. 21). The maximum fluctuation of the average bed elevation for this discharge range is approximately $5.7 \mathrm{ft}$ (fig. 12A). As with the $100,000 \mathrm{ft}^{3} / \mathrm{s}$ range, there are measurements that have similar or exact discharges and demonstrate variability of stage with time associated with temperature or seasonal variations, rising or falling stage, or error in measurement.

The cross sections extracted from the seven non-boat measurements in the $600,000 \mathrm{ft}^{3} / \mathrm{s}$ range show the least fluctuation overall, but still as much as $16 \mathrm{ft}$ in some locations (fig. 22). The cross sections for the first and last measurements are similar on the side of the channel to the left of the channel centerline, and the last measurement section is approximately $6 \mathrm{ft}$ higher than the first on the side of the channel to the right of the channel centerline. Many of the measurements in this discharge range are close to one another in time, usually on the rising and falling limbs of the hydrograph for a given event. The two measurements in April 1945 and the two measurements in June 1947 do not display the typical hysteresis of measurements on the rising and falling limbs of the hydrograph. In both cases, the measurement on the rising limb of the hydrograph was 600,000 $\mathrm{ft}^{3} / \mathrm{s}$ (April 20, 1945, and June 18, 1947), but the measurement on the falling limb had a larger discharge $\left(606,000 \mathrm{ft}^{3} / \mathrm{s}\right.$ for April 23, 1945 and 608,000 $\mathrm{ft}^{3} / \mathrm{s}$ for June 20, 1947). The stage on April 20, 1945, was slightly lower than on April 23, and the average bed elevation on April 20 was $367.08 \mathrm{ft}$ compared to $366.99 \mathrm{ft}$ on April 23, which indicates there was an increase in discharge with little to no change in stage or average bed elevation from April 20 to April 23. The stage on June 18, 1947, was slightly higher than on June 20 (fig. 22), and the average bed elevation on June 18 was $366.85 \mathrm{ft}$ compared to $367.11 \mathrm{ft}$ on June 20, which again indicates an increase in discharge with little to no change in stage or average bed elevation from June 18 to June 20. In both of these events, the average velocity of the measurement made on the rising limb of the hydrograph was less than the velocity of the measurement made on the falling limb.

\section{Poplar Street Bridge}

Cross sections extracted from 39 non-boat measurements in the $100,000 \mathrm{ft}^{3} / \mathrm{s}$ range at the Poplar Street Bridge are shown in figure 23 . The cross section from the last measurement defines the lower-most extent of the sections in the center and right sides of the channel. Between the first and last measurements, the cross sections generally lowered approximately $6 \mathrm{ft}$. Overall, the cross sections fluctuated by as much as $16 \mathrm{ft}$ in some locations. The maximum fluctuation of the average bed elevation is approximately $9.4 \mathrm{ft}$ for this discharge range (fig. 12A).

Similarly, cross sections extracted from 19 non-boat measurements in the $400,000 \mathrm{ft}^{3} / \mathrm{s}$ range fluctuated as much as $17 \mathrm{ft}$ in some locations (fig. 24). The maximum fluctuation of the average bed elevation for this discharge range is approximately $5.0 \mathrm{ft}$ (fig. 12A). Despite the overall fluctuations, the cross sections for the first and last measurements are similar for this discharge range. The measurement on March 21, 1978, had a discharge at the upper end of the range, but had the lowest stage for this range, whereas the measurement on May 29, 1984, had the highest stage for this range at a similar discharge, typical of temperature effects.

The cross sections extracted for 7 non-boat measurements in the $600,000 \mathrm{ft}^{3} / \mathrm{s}$ range indicate the least amount of fluctuation of all the discharge ranges examined, but still fluctuate as much as $13 \mathrm{ft}$ in some locations (fig. 25). The cross sections for the first and last measurements exhibit moderate fluctuation, with approximately $5 \mathrm{ft}$ of rise on the left side of the channel, and approximately $6 \mathrm{ft}$ of lowering on the side of the channel to the right of the channel centerline.

\section{Chester, Illinois}

Cross sections extracted for 107 non-boat measurements in the $100,000 \mathrm{ft}^{3} / \mathrm{s}$ range at the Chester Bridge are shown in figure 26 . The bed has fluctuated substantially through the period of record, by $26 \mathrm{ft}$ on the left side of the channel and 


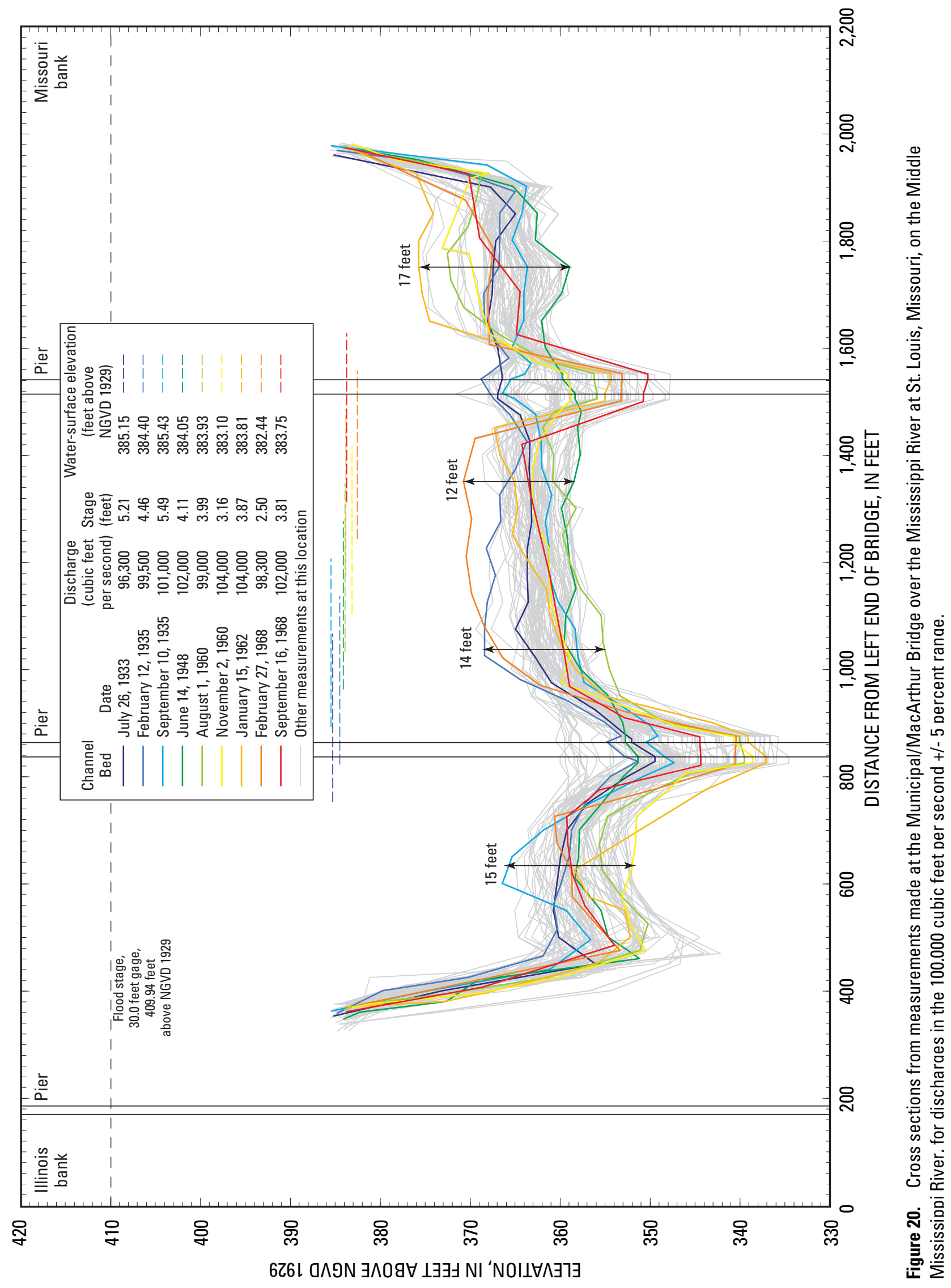




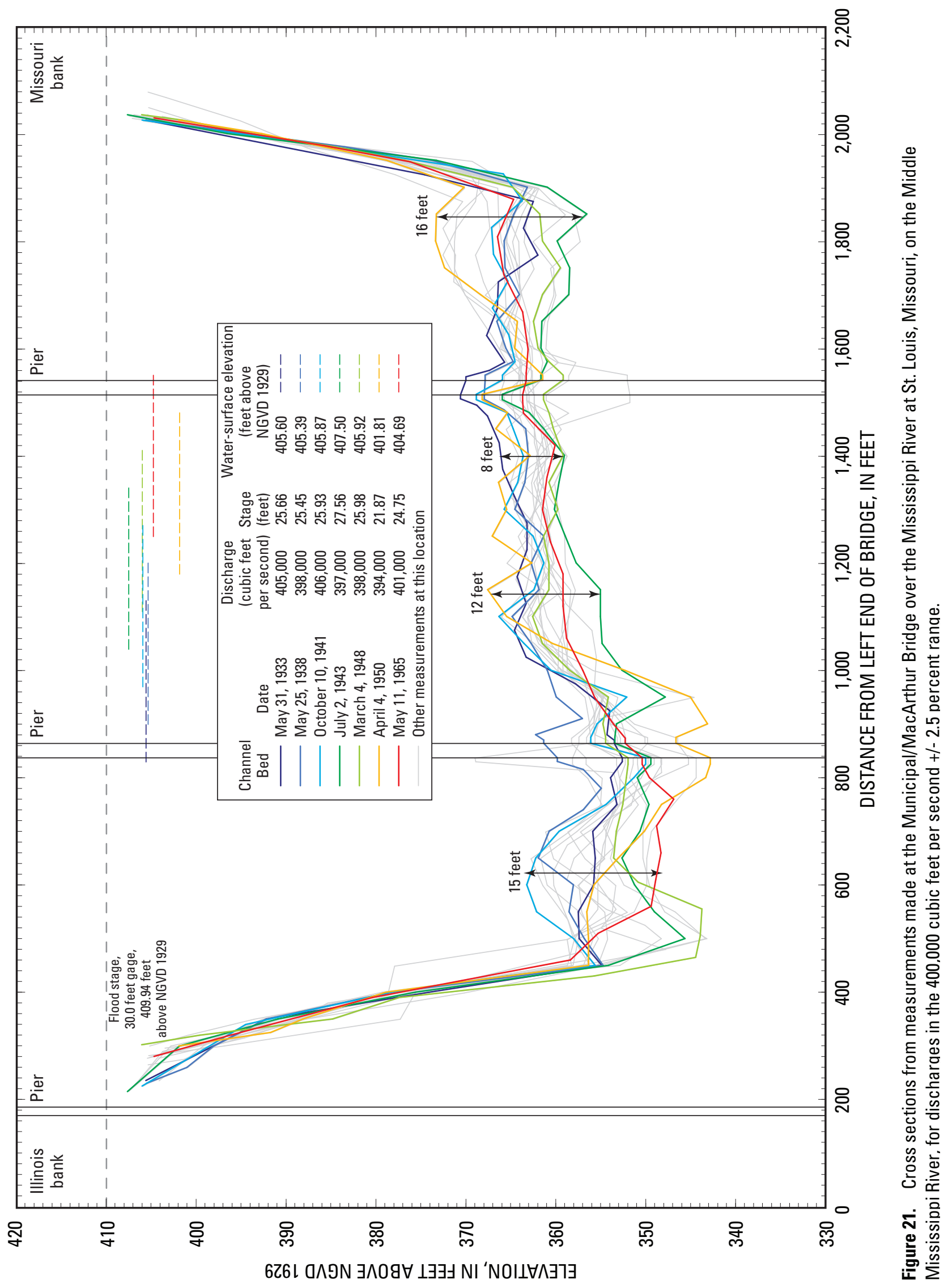




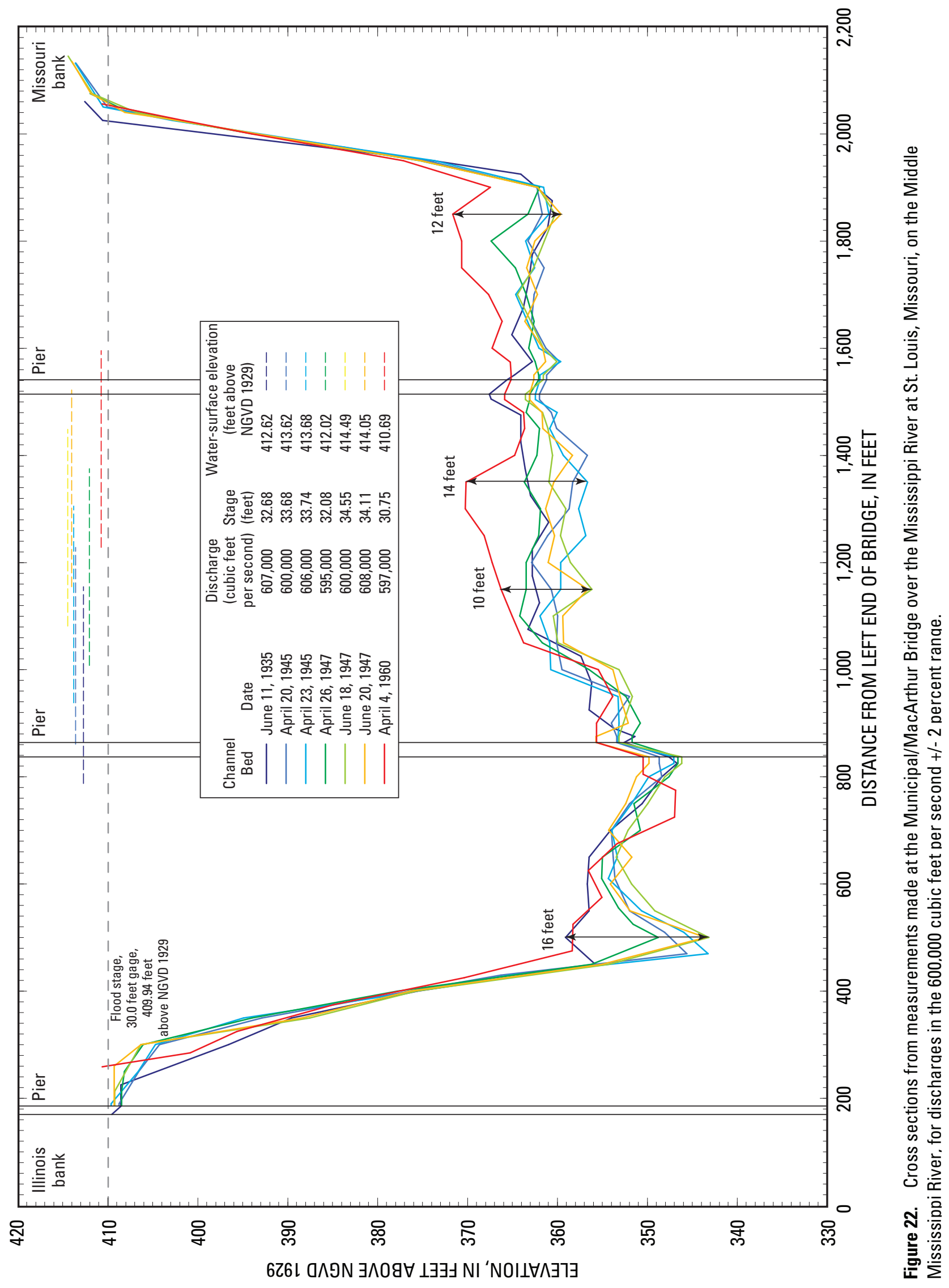




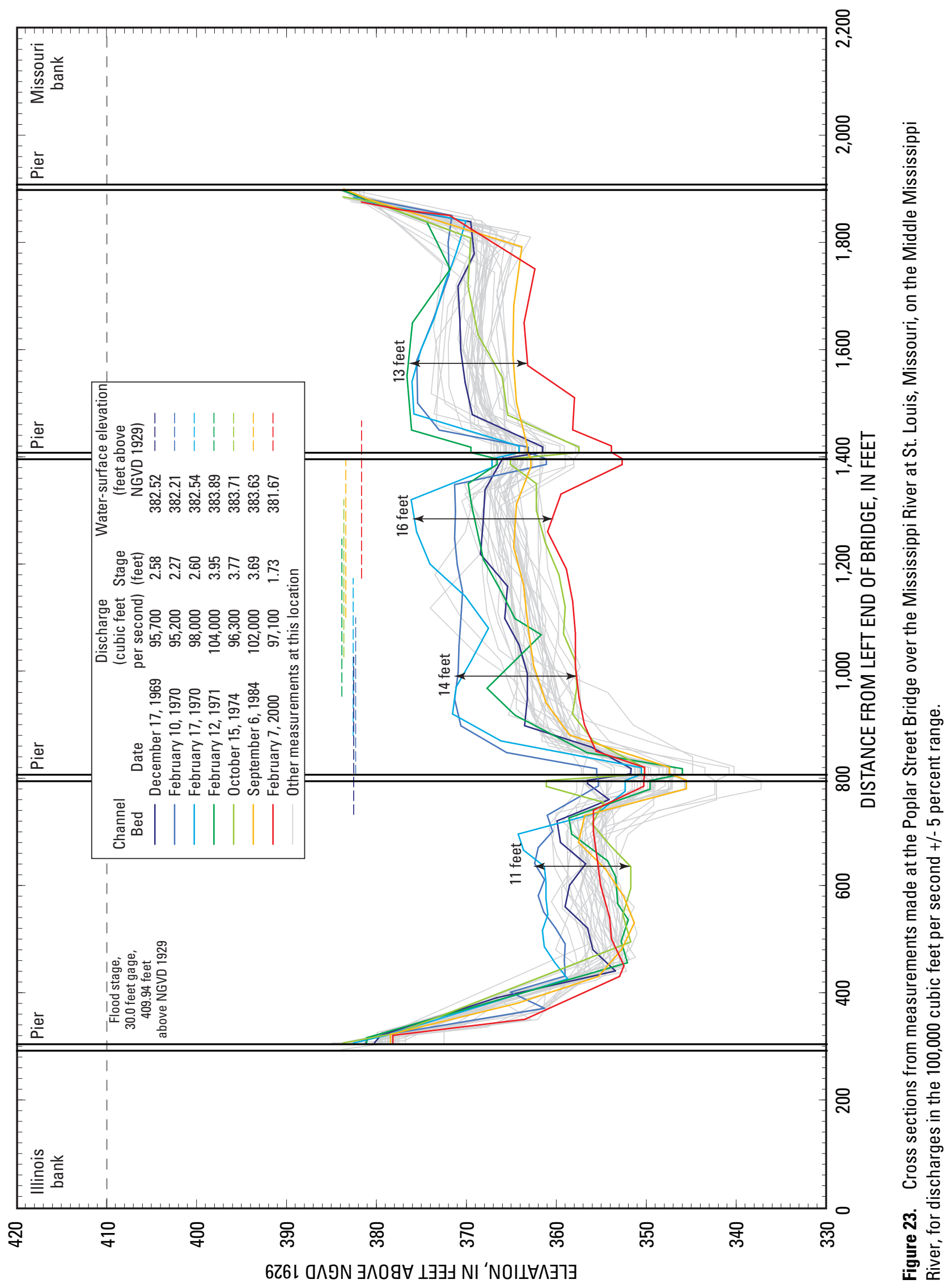




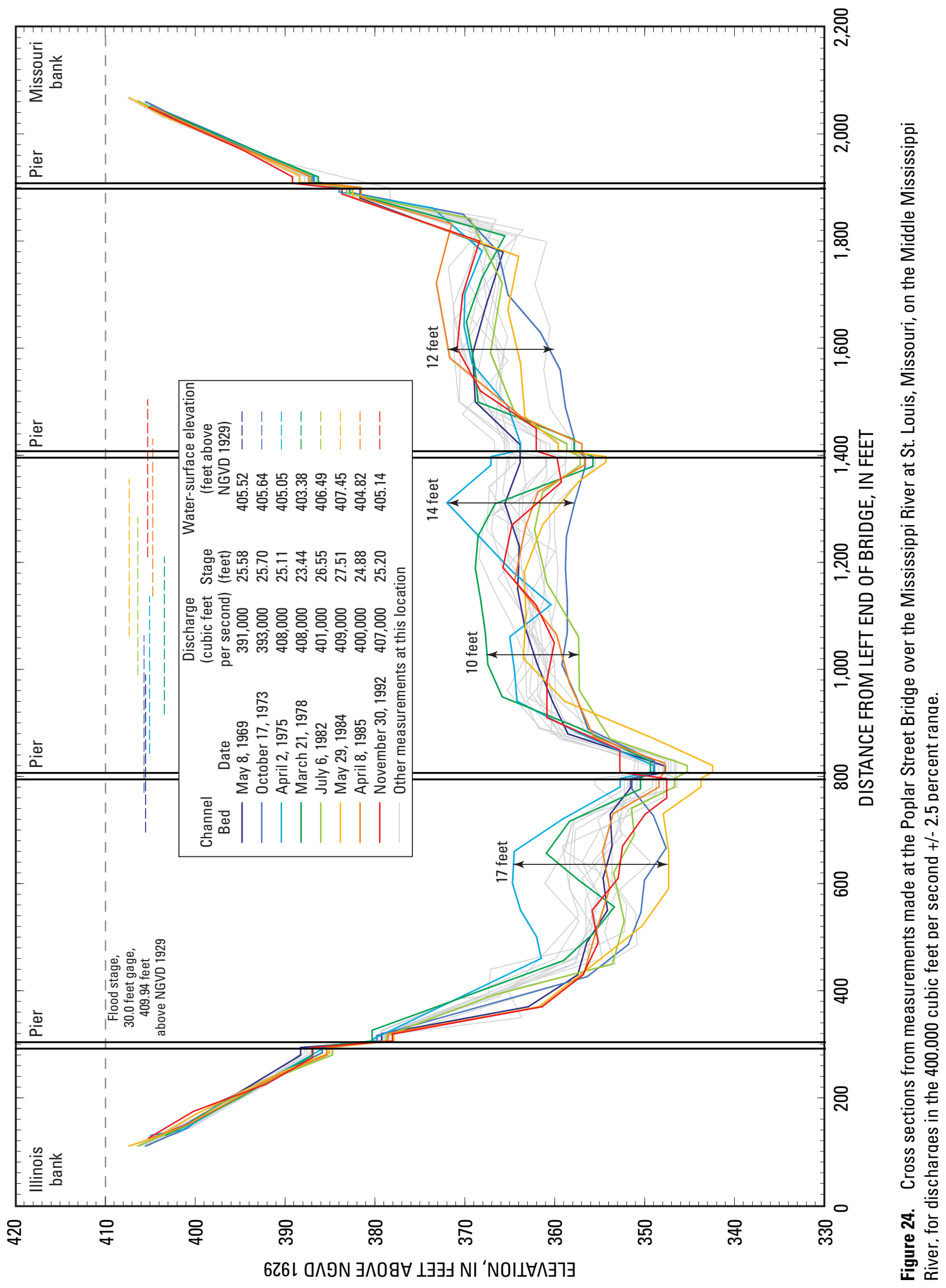




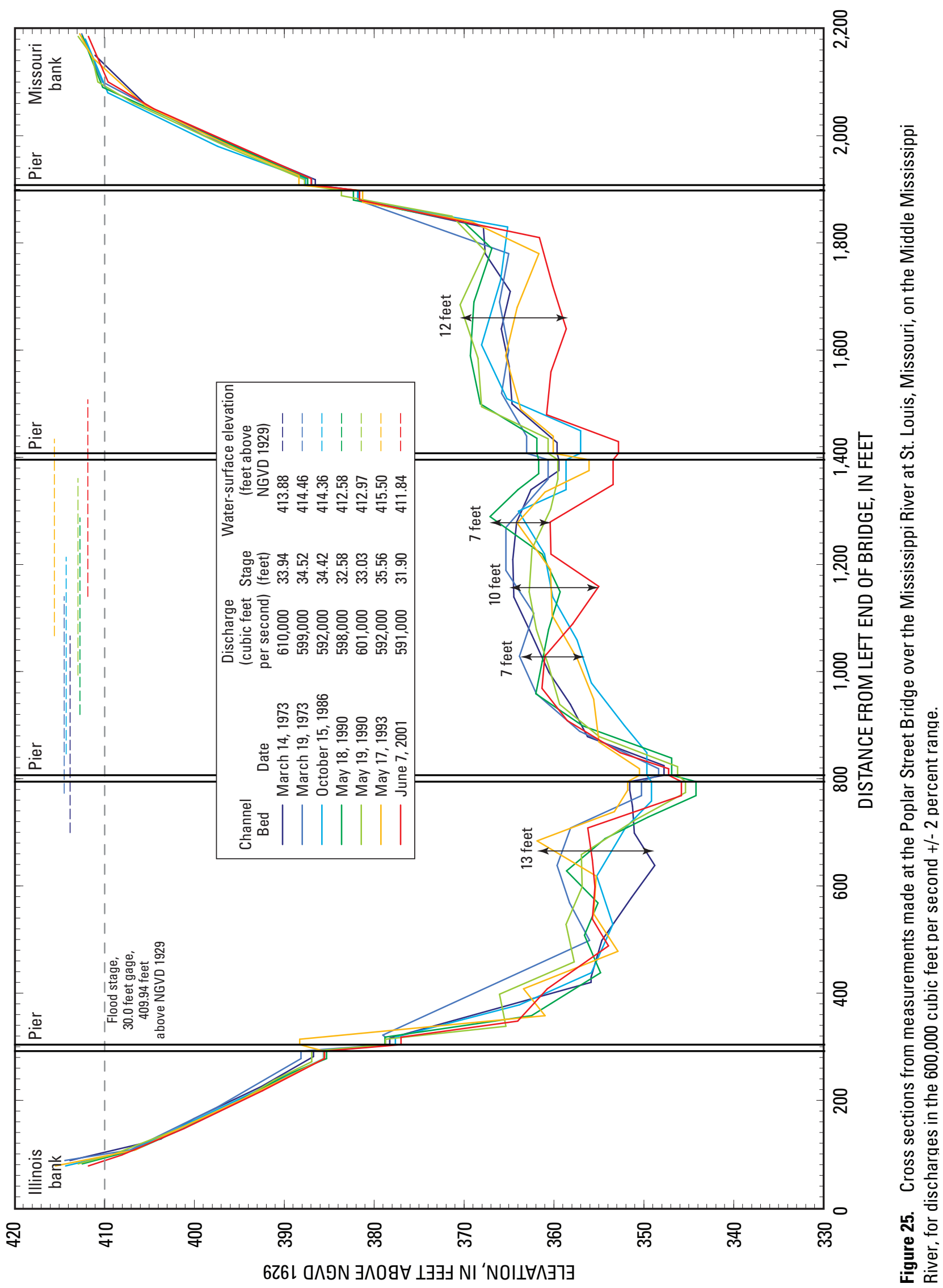




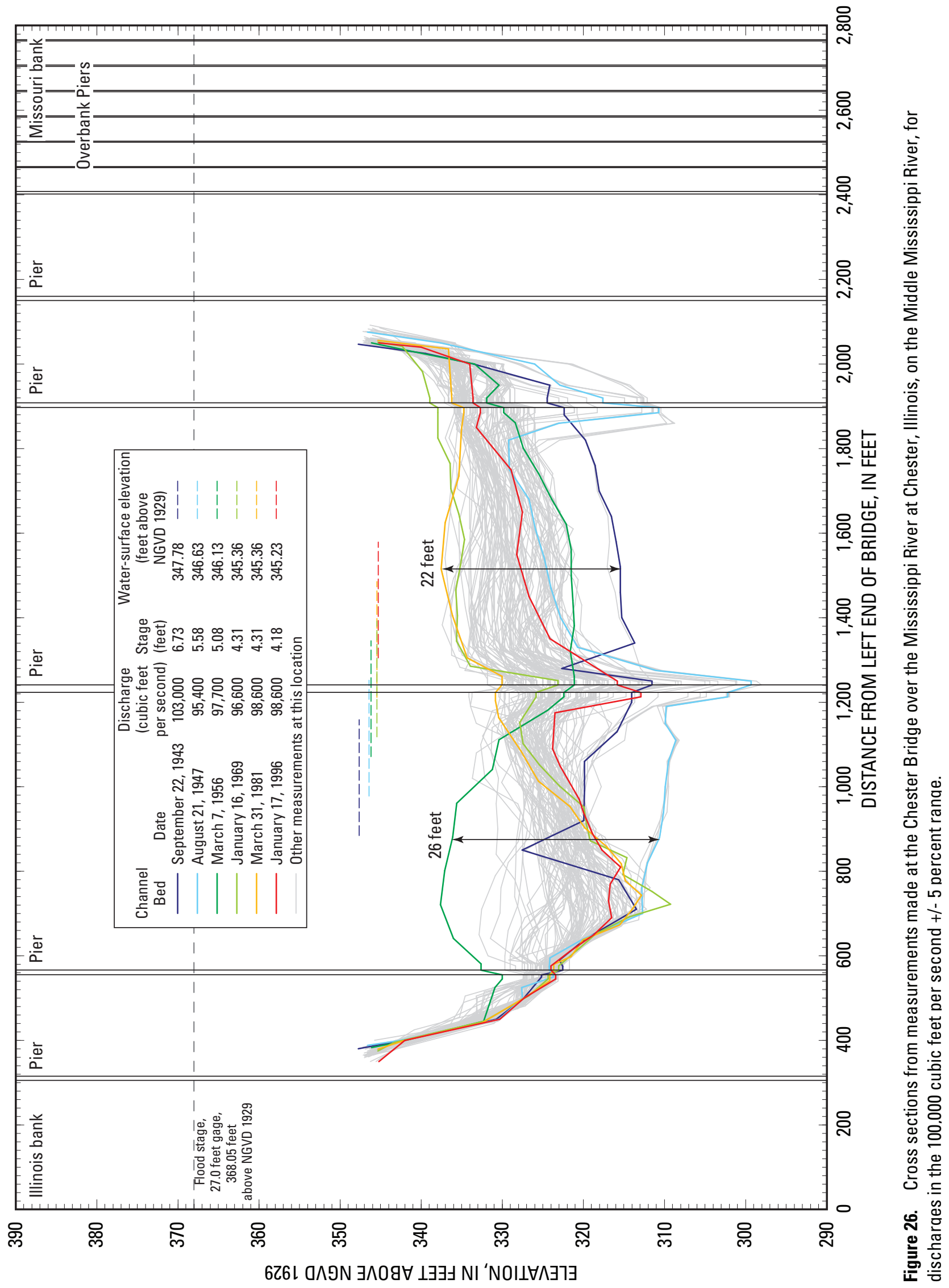


$22 \mathrm{ft}$ on the right side. The thalweg of the channel shifted from the right side of the channel to the left side between September 22, 1943, and August 21, 1947, to the left side again by March 15,1956 , and to the right side again by January 16,1969 . The maximum fluctuation of the average bed elevation is approximately $11.2 \mathrm{ft}$ for this discharge range (fig. 12B).

The series of dikes built or extended upstream from the Chester gage in the early 1970s (fig. 2) appeared to have a small effect on average velocity (fig. $11 B$ ) and average bed elevation (figs. $12 B$ and 13). Cross sections for measurements in the $100,000 \mathrm{ft}^{3} / \mathrm{s}$ range at the Chester Bridge from 1966 through 1996 are shown in figure 27, and it is apparent that the cross sections stabilize in a narrower band after 1966. The maximum fluctuation from 1966 on was about $12 \mathrm{ft}$ and the thalweg consistently remains on the left side of the channel. The cross sections from the first and last measurements are similar for this time. The maximum fluctuation of the average bed elevation for this time is $4.7 \mathrm{ft}$ (fig. 12B).

Cross sections extracted from 20 non-boat measurements in the $400,000 \mathrm{ft}^{3} / \mathrm{s}$ range at the Chester Bridge fluctuated as much as $20 \mathrm{ft}$ on the left side of the channel and $26 \mathrm{ft}$ on the right side (fig. 28). The maximum average bed elevation fluctuation for this discharge range is approximately $10.3 \mathrm{ft}$ (fig. $12 B$ ). As with the $100,000 \mathrm{ft}^{3} / \mathrm{s}$ range, the channel thalweg shifts back and forth from the right side of the channel to the left side during the period of record; however, cross sections display much less variability after the mid-1960s (fig. 29), with approximately $11 \mathrm{ft}$ of fluctuation. The maximum fluctuation of the average bed elevation for this time is $4.0 \mathrm{ft}$ (fig. $12 B$ ). As with the $100,000 \mathrm{ft}^{3} / \mathrm{s}$ range, this stabilization likely is caused by the dike field work upstream from the Chester Bridge.

The cross sections extracted from 11 non-boat measurements in the $600,000 \mathrm{ft}^{3} / \mathrm{s}$ range indicate the least fluctuation for the period of record, but still as much as $21 \mathrm{ft}$ in some locations (fig. 30). The bed configurations for the first and last measurements are similar. Although the cross sections for measurements after the mid-1960s indicate the same fluctuation of $15 \mathrm{ft}$ on the right side of the channel, the fluctuations of the thalweg on the left side of the channel are substantially less after the dike field work upstream from the Chester Bridge (fig. 31). The cross sections for the first and last measurements of this time remain similar. The overall stabilizing effect of the dike field observed in the $100,000 \mathrm{ft}^{3} / \mathrm{s}$ and $400,000 \mathrm{ft}^{3} / \mathrm{s}$ ranges is less for the $600,000 \mathrm{ft}^{3} / \mathrm{s}$ range because the effects of the dike field would tend to "wash out" with more than $15 \mathrm{ft}$ of water over the dikes.

\section{Flood of 1993}

The flood of 1993 on the upper Mississippi River Basin was one of the costliest floods in the history of the United States (Johnson and others, 2004). The magnitude and severity of the flood makes it one of the greatest natural disasters to have struck this country. When the magnitude of the flood began to be realized, the USGS began making almost daily measurements at the St. Louis gage, and made measurements at the Chester gage almost every other day. The cross-section data from these measurements provide a timeline through the event at these two stations.

Cross sections extracted from measurements at the Poplar Street Bridge at the St. Louis gage are shown in figure 32. The measurements shown are those that are more than flood stage at the St. Louis gage ( $30 \mathrm{ft}$ ). During the course of the flood, the bed fluctuated approximately $24 \mathrm{ft}$ on the left side, approximately $13 \mathrm{ft}$ in the middle, and approximately $12 \mathrm{ft}$ on the right side of the channel. The bed configuration near the peak from July 30 to August 1 was at the extreme low end of the fluctuation (fig. 33); however, near the earlier peak on July 21, the bed was at the extreme high end of the fluctuation, higher on the left side of the channel on July 17, and higher in the middle on July 22 (fig. 33). The bed configuration near the end of the event on August 15 was similar to the configuration at the beginning of the event; however, by August 31, the right side was approximately $6 \mathrm{ft}$ higher than at the beginning of the flood, and the left side was approximately $10 \mathrm{ft}$ lower. Although the main thalweg remains towards the outside of the channel bend on the left side of the channel, the substantial fluctuation of the cross sections within the span of a few days indicates substantial movement of bed sediment through the section. An animation of the daily sections displays this movement more clearly (St Louis. mwv).

The cross sections extracted from measurements at the Chester Bridge displayed approximately the same magnitude of fluctuation as was seen at the St. Louis gage (fig. 34). During the course of the flood, the cross sections fluctuated approximately $12 \mathrm{ft}$ on the right side of the channel, and by 18 or more $\mathrm{ft}$ in the thalweg on the left side. The true depth of the thalweg was not measured from the Chester Bridge; the measuring rig lacked sufficient cable to sound the depth in the deepest part. For this reason, measurements after July 30 until the peak on August 5 were made with a boat and ADCP. The measurements shown in figure 34 are those more than a 32-ft stage at the Chester gage and span the same time as was shown for the St. Louis gage (figs. 32 and 33). The cross sections at the Chester gage (fig. 34) indicate steady degradation until the measurement near the peak, and then steady aggradation in the thalweg after the peak. The degradation on the right side of the channel up to the flood peak was more permanent, 


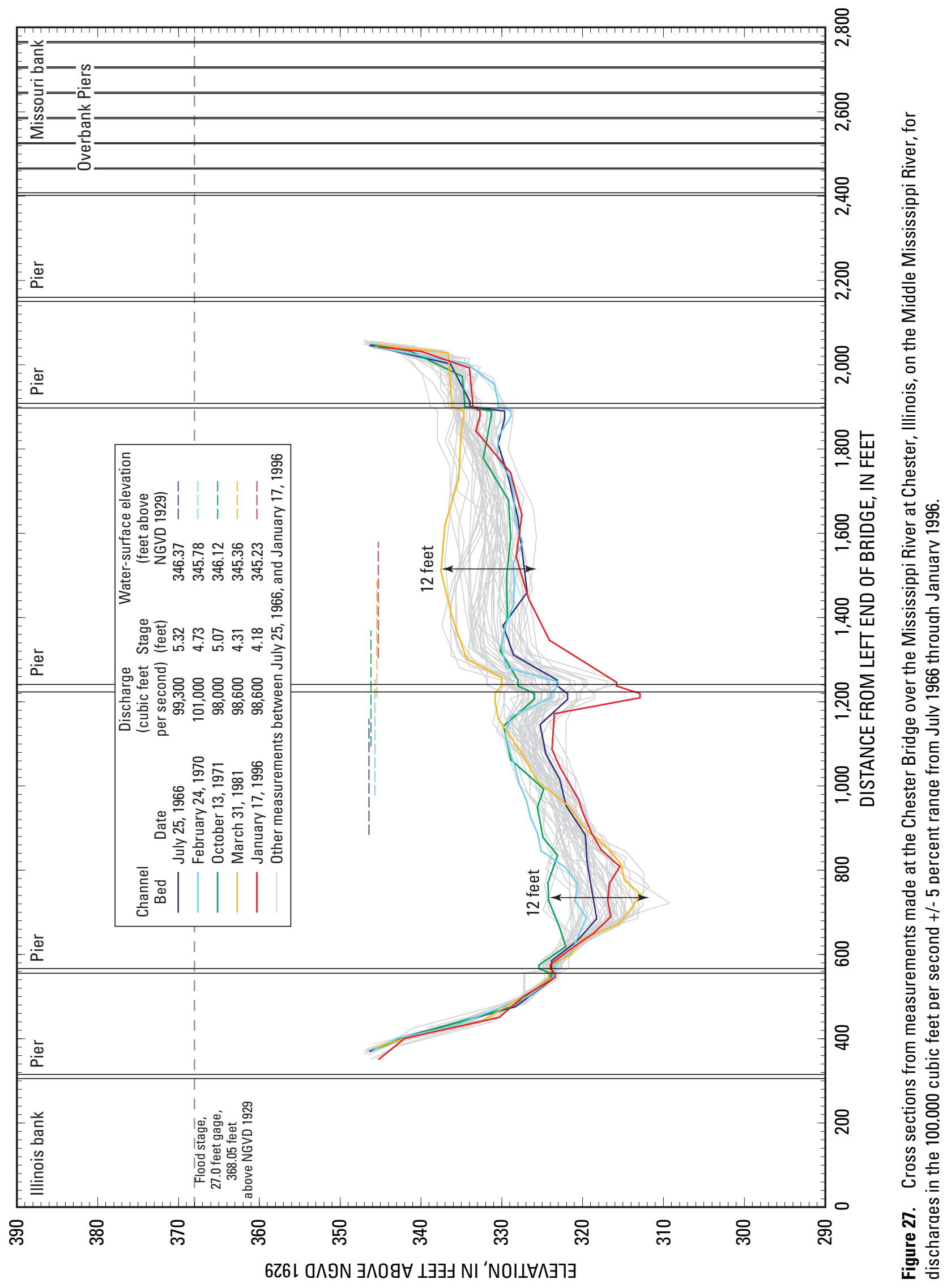




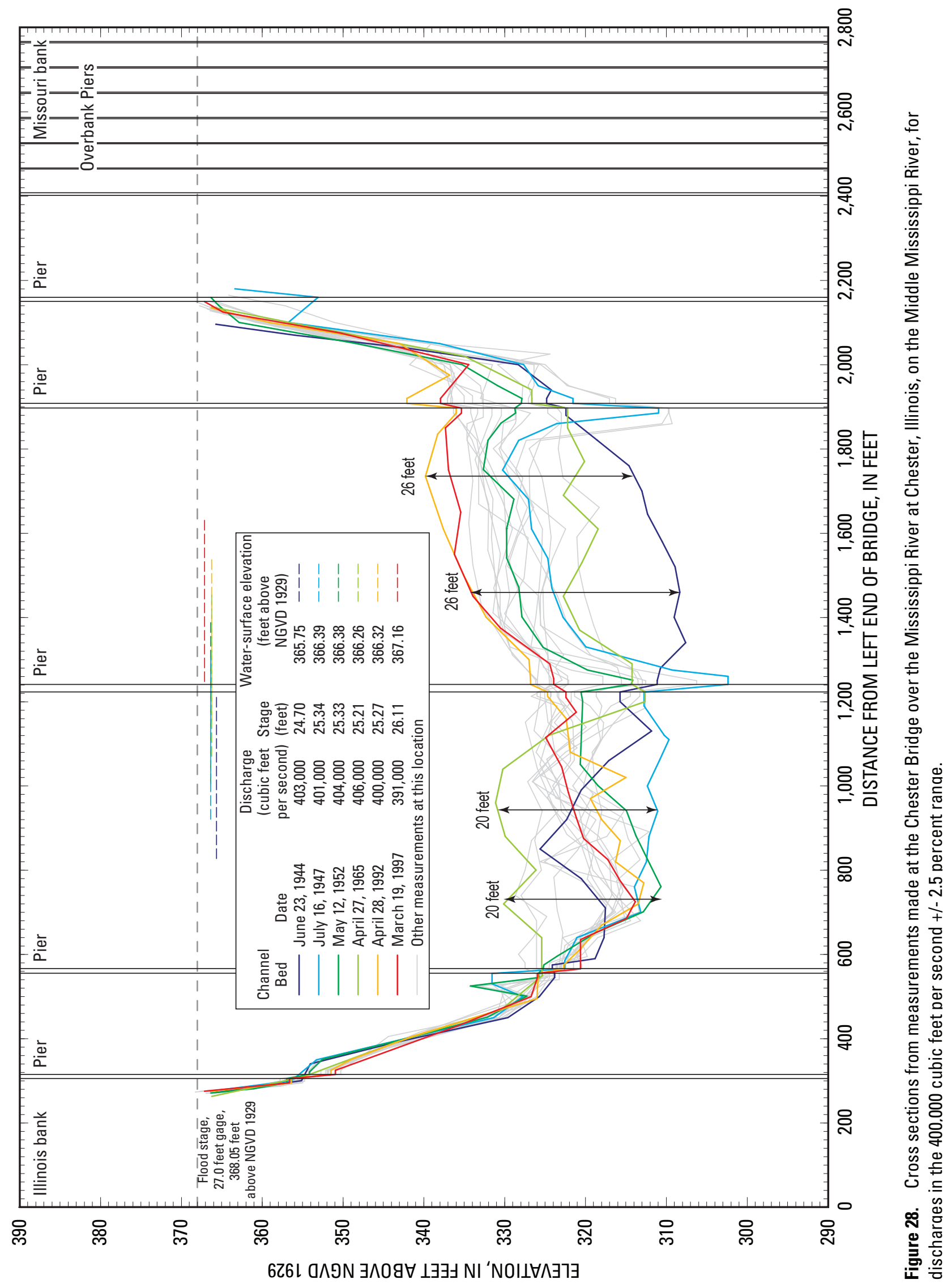




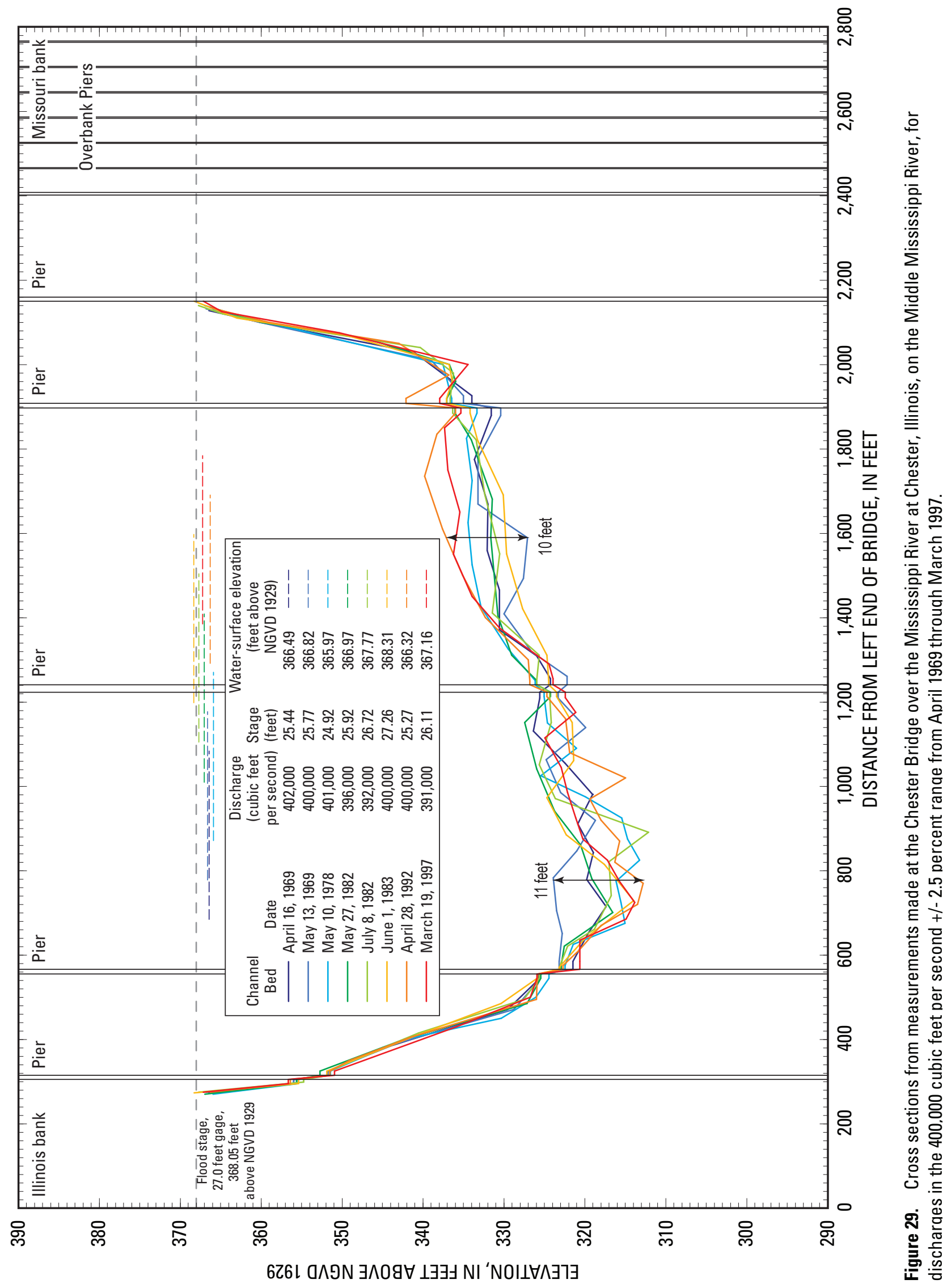




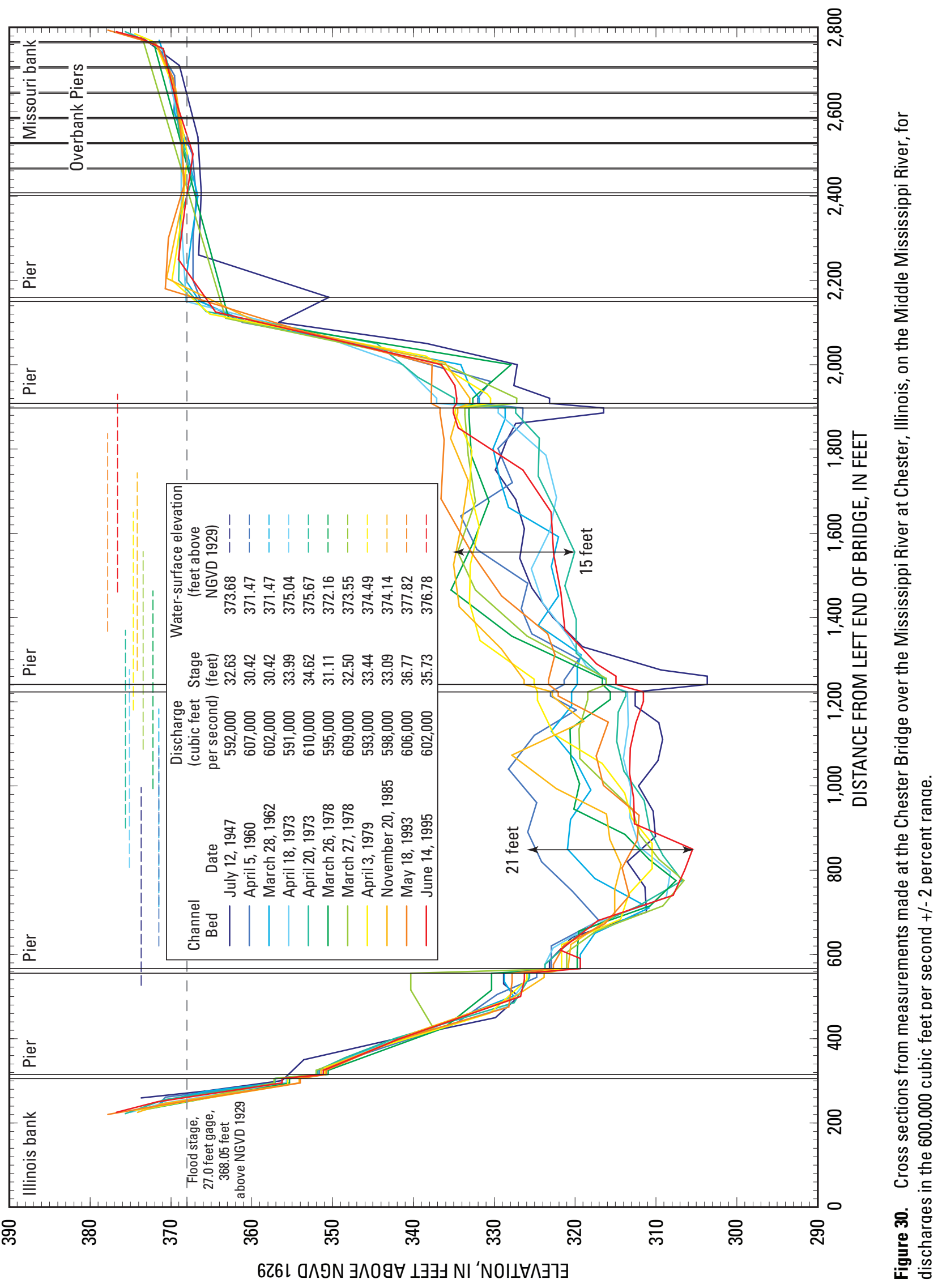




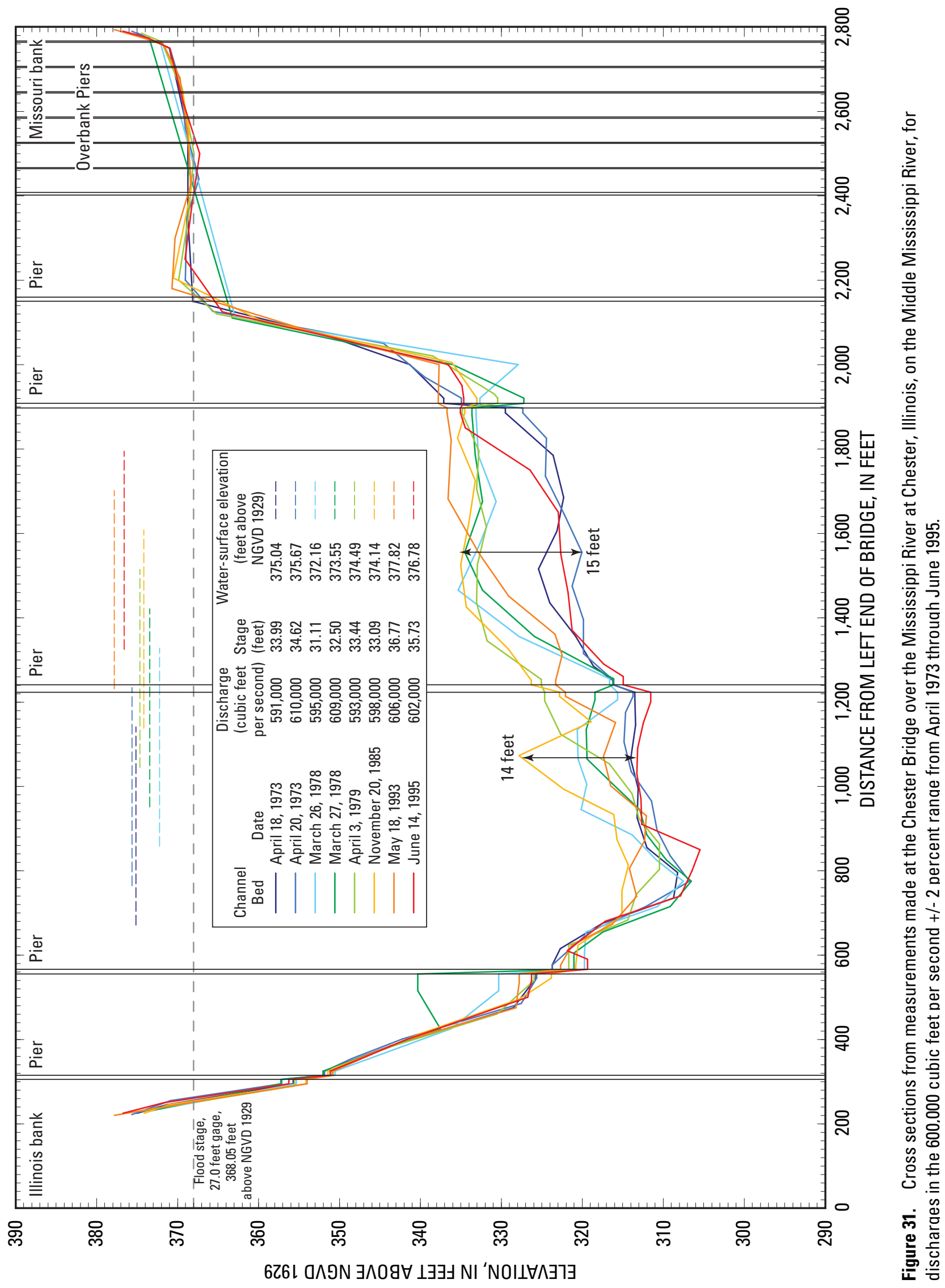




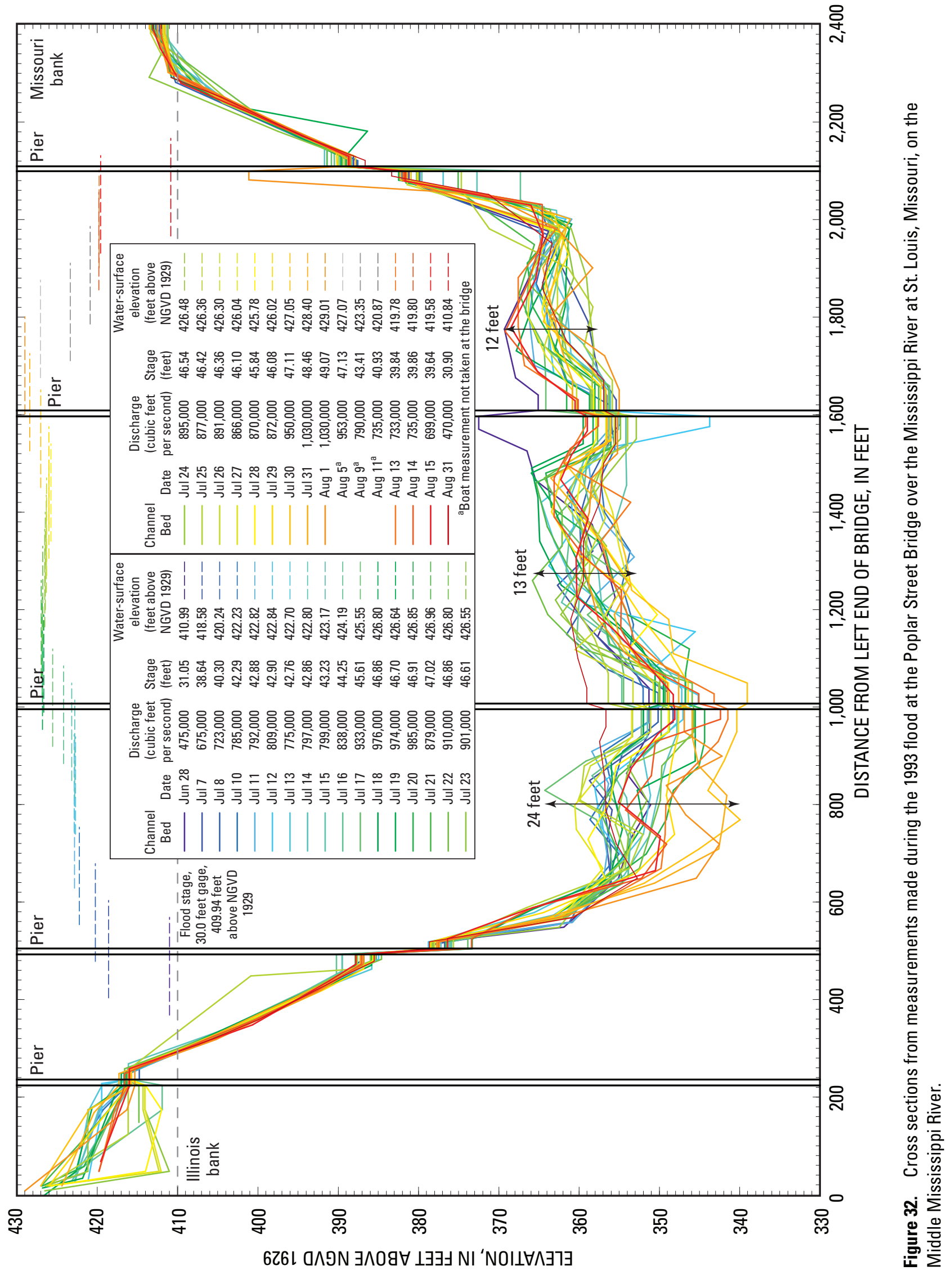




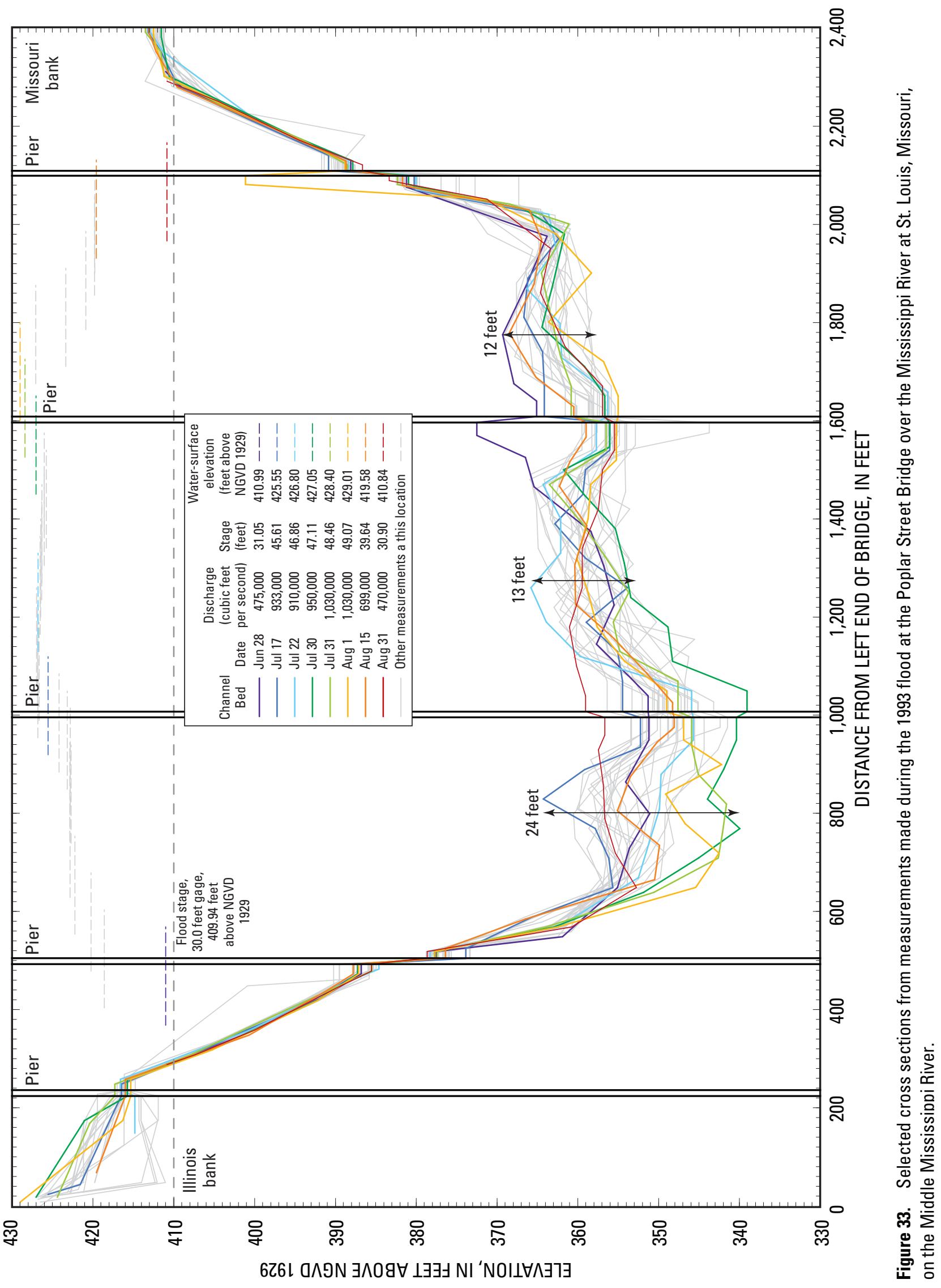




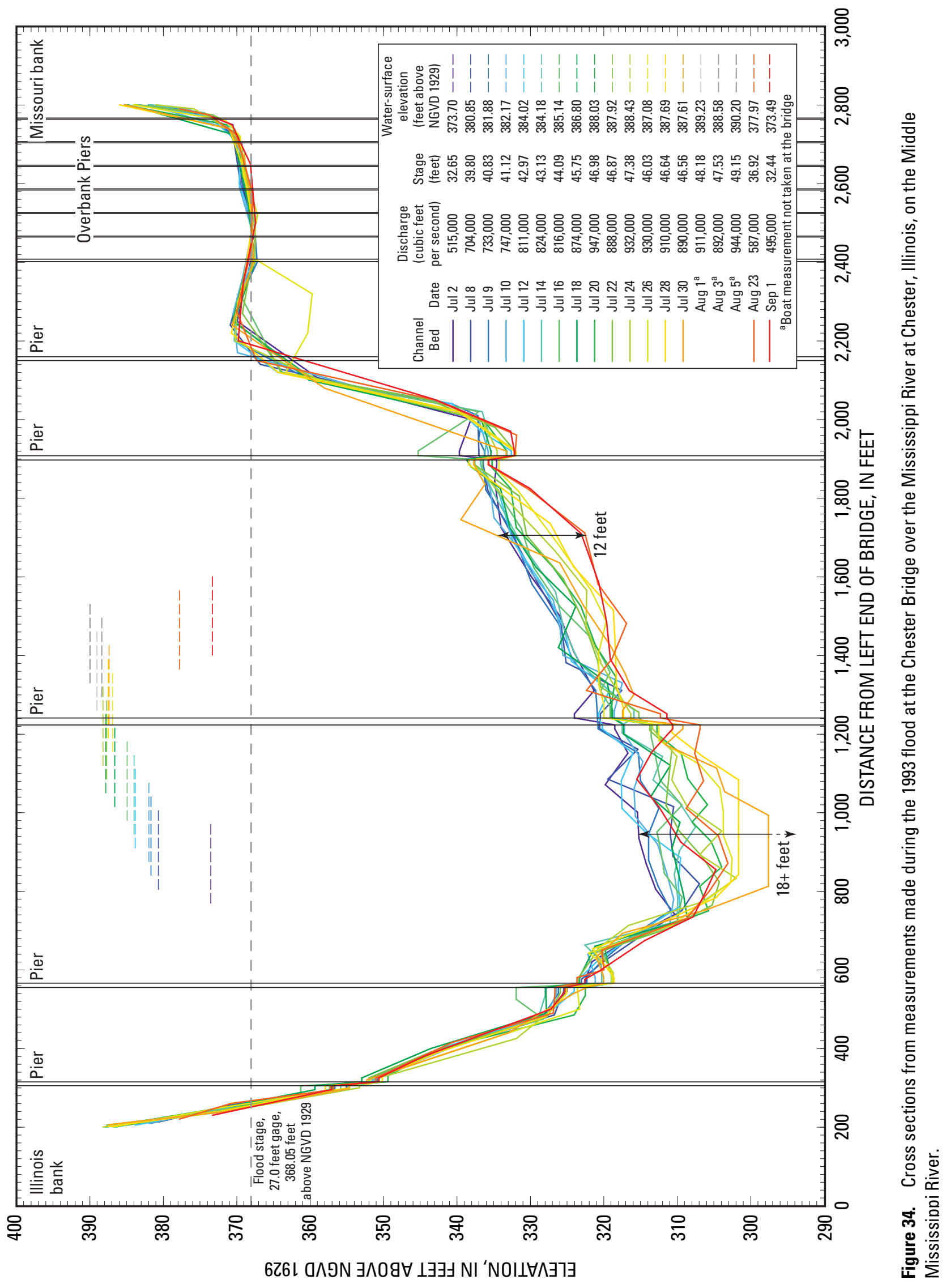


and likely is part of the slow recovery of the average bed elevation for in-channel flows seen after the 1993 flood (fig. 13). An animation of the sections displays this movement (Chester.mwv).

\section{Summary and Conclusions}

Data from three gages operated by the U.S. Geological Survey (USGS) on the Middle Mississippi River (MMR) were examined. Data from measurements made at the streamgages at St. Louis, Missouri, and Chester, Illinois, during the period of operation by the USGS (1933-2008) were examined to determine stage-discharge relation changes through time and to investigate cause-and-effect mechanisms through evaluation of hydraulic geometry and channel elevation data. Additional historic daily stage and discharge data from archives of the U.S. Army Corps of Engineers (USACE) for the streamgages at St. Louis and Chester (1891-2008), as well as the continuous stage-only gage at Cape Girardeau (1896-2008), Missouri, were examined to determine stage-discharge relation and water-surface elevation changes through time before and during the period of operation by the USGS for other potential cause-and-effect mechanisms.

Measured stage and computed discharge data from measurements at the streamgages at St. Louis and Chester indicated that the measured stage for a given discharge range has been changing with time. At the St. Louis streamgage, the stage from measurements has decreased with time for discharges below approximately 400,000 cubic feet per second $\left(\mathrm{ft}^{3} / \mathrm{s}\right)$ and increased with time above that discharge. At the Chester streamgage, the stage has decreased with time for discharges below approximately $300,000 \mathrm{ft}^{3} / \mathrm{s}$, and increased with time above that discharge.

The stage-discharge relations, or "ratings," used through time at the two streamgages also indicated similar results to those observed with individual measurements. There has been a decrease in rated stage for a given discharge at lower discharges with time, and there has been an increase in rated stage for a given discharge at higher discharges with time at both streamgages. At the Chester streamgage, the rated stage for a given discharge appeared to be consistently increasing with time for discharges greater than $500,000 \mathrm{ft}^{3} / \mathrm{s}$; however, at the St. Louis streamgage, the rated stage for a given discharge appeared to be steady or decreasing with time since the 1960s, even for the largest discharges.

The two different measurement locations used at the St. Louis streamgage are clearly evident in the different relations between top width from measurements and discharge. Top widths from measurements for a given discharge with time also indicates the change in measurement location; however, for a given measurement location, the top widths from measurements for a given discharge have been relatively constant. The average velocities from measurements for a given discharge at the St. Louis streamgage also have been relatively constant through time, with occasional fluctuations that appear to be related to the occurrence of moderate to large floods.

The relation between top widths from measurements and discharge at the Chester streamgage had three distinct bands, and the overlap of two of the bands implied that a given discharge could occur at two different stages. Examination of these data with time revealed that the conditions to initiate flow in the Horse Island Chute overflow channel have changed with time; in the 1940s, flow occurred in Horse Island Chute at any discharge greater than approximately $100,000 \mathrm{ft}^{3} / \mathrm{s}$, and by 1973, flow occurred in Horse Island Chute only for discharges greater than $300,000 \mathrm{ft}^{3} / \mathrm{s}$. The top widths from measurements for a given discharge have been constant through time when adjusted to remove the part of the flow in Horse Island Chute. Average velocities from measurements for a given discharge at the Chester streamgage appeared to be increasing slightly with time, particularly after 1970, possibly as the result of a series of dikes built or extended in the channel immediately upstream from the Chester streamgage.

Average bed elevations at the St. Louis streamgage appeared to be lowering with time, with a distinct break in the data when the measurement location moved in 1968. The average bed elevation for a given discharge appeared to be increasing slowly with time at the Chester streamgage; however, the average bed elevation for all discharges less than bankfull has fluctuated around an average value from 1948 to 2000, with a decrease between 1951 and 1960, a steady increase between 1961 and 1993, and several abrupt fluctuations after 1993 that appear to be related to the large floods of 1993 and 1995.

The apparent decrease in stage with time for lower discharges (less than one-half bankfull) at the St. Louis streamgage appears to be linked to the general lowering of the average bed elevation. The top widths and average velocities from measurements have remained relatively constant at each of the measurement locations at the St. Louis streamgage, so the lowering of the average bed elevation with time results in a lowering of the stage with time for in-channel flows. The lowering of the average bed elevation with time likely is caused by a combination of dikes in the channel, which cause channel deepening in the thalweg of the channel at the end of the dikes, and a general decrease in sediment flux into the MMR, which results in less incoming sediment to replace outgoing sediment in the MMR.

The apparent increase in stage with time for increased discharges (greater than bankfull) at the St. Louis streamgage appears to be linked to the completion of levees on the flood plains, particularly the Alton-Gale levee system completed in the mid-1960s. As levee projects have been completed through time, the measured and rated stages for a given discharge have increased; however, after the completion of the Alton-Gale levee system in the mid-1960s, rated stages for a given discharge have decreased. Because the top widths and average velocities from measurements for higher discharges are relatively constant with time, the general lowering of the 
average bed elevation with time results in a lowering of the rated stages for a given discharge with time at the St. Louis streamgage, even at discharges greater than flood stage.

The apparent decrease in stage with time for lower discharges is less pronounced at the Chester streamgage than at the St. Louis streamgage, because there is less lowering in average bed elevations with time at the Chester streamgage. However, the average velocities from measurements increase slightly with time for in-channel flows, and this offsets the relatively constant top widths and average bed elevations from measurements, resulting in a decrease in measured and rated stages with time for in-channel flows. The apparent increase in stage for a given discharge with time for increased discharges is more pronounced at the Chester streamgage than at the St. Louis streamgage, and likely is a combination of the completion of levees on the flood plains and the infilling of the inflow channel to the Horse Island Chute overflow channel with time, which has decreased the amount of flow carried by this overflow channel with time.

In addition to the measurement records examined at the two streamgages for the period of operation by the USGS, the daily stage and discharge values from historic archives of the USACE were examined for the St. Louis streamgage. These historic data for the St. Louis streamgage displayed distinct "rating lines" before USGS operation, implying the daily discharge values simply were obtained from the rating based on the daily stage value at 8:00 AM each day. There was a sudden and substantial decrease of nearly 24 percent in the upper end of the ratings for discharge at a given stage between 1932 and 1933 when USGS began operation; this sudden change likely is the result of the change to the Price AA current meter from other, less-accurate methods for discharge measurements. Based on modeling results for the MMR by the USACE and the findings of this study, the accuracy of the historic record before 1933 is questionable, and needs to be examined further.

Historic stage data for the two streamgages and the stage-only gage at Cape Girardeau, Missouri, before and during USGS operation also were examined. The difference in water-surface elevation between St. Louis and Chester, between Chester and Cape Girardeau, and between St. Louis and Cape Girardeau were examined. The difference in watersurface elevation between St. Louis and Chester and between St. Louis and Cape Girardeau displayed a steady decrease from the 1890s to the 1930s, whereas the difference was nearly constant between Chester and Cape Girardeau for this time. The Kaskaskia cutoff in 1881 likely was the cause of the steady decrease between St. Louis and Chester, and it took from 1881 until the 1930s for the river to fully adjust after the cutoff. Other small but abrupt changes in the difference in water-surface elevation between St. Louis, Chester, and Cape Girardeau appear to be related to large flood events, as well as smaller floods during periods of low flow.

Cross sections were extracted from measurement notes for three discharge ranges for the two streamgages, and were examined through time. All of the cross sections displayed substantial variability through time, likely resulting from the effects of temperature, seasonal variations, and rising and falling stage. The cross sections for both measurement locations at the St. Louis streamgage and for the Chester streamgage displayed substantial variability for a given discharge range, but the variability decreased for the Chester streamgage sections after the early 1970s when work was done on a dike field immediately upstream from the Chester streamgage, particularly for the $100,000 \mathrm{ft}^{3} / \mathrm{s}$ and $400,000 \mathrm{ft}^{3} / \mathrm{s}$ discharge ranges. The cross sections from the $600,000 \mathrm{ft}^{3} / \mathrm{s}$ discharge range displayed the least overall variability through time at all measurement locations, but the stabilization from the dike work near the Chester streamgage had the least effect on cross sections in this discharge range because the effects of the dike field would "wash out" with more than $15 \mathrm{ft}$ of water over the tops of the dikes. Cross sections from measurements made during the flood of 1993 indicated the substantial variability of these sections with changing discharge in a single flood event. Substantial movement of bed sediments was apparent in the sections for the St. Louis streamgage during the 1993 flood, and the cross section at the flood peak was at the lowest extent of the range observed during the flood. At the Chester streamgage, the cross sections steadily lowered until the 1993 flood peak, and then rose to a level somewhat lower than before the flood. 


\section{References Cited}

Biedenharn, D.S., and Watson, C.C., 1997, Stage adjustment in the Lower Mississippi River, USA: Regulated RiversResearch and Management, v. 13, no. 6, p. 517-536.

Brauer, E.J., Busse, D.R., Strauser, C., Davinroy, R.D., Gordon, D.C., Brown, J.L., Myers, J.E., Rhoads, A.M., and Lamm, D., 2005, Geomorphology Study of the Middle Mississippi River: U.S. Army Corps of Engineers, Prepared for Mississippi River Stakeholders, $43 \mathrm{p}$, http://www.mvs. usace.army.mil/eng-con/expertise/arec/Model\%20Study\%20 Report\%20PDFs/GeomorphologyMiddleMississippiRiver/ GeomorphologyMiddleMississippi.pdf, accessed August 20, 2009.

Brauer, E.J., 2009, The limitations of using specific-gage analysis to analyze the effect of navigation structures on flood heights in the Middle Mississippi River: Permanent International Association of Navigation Congress, 2009 De Paepe-Williams Award Contest, 18 p.

Buchanan, T.J, and Somers, W.P., 1968, Stage measurement at gaging stations: U.S. Geological Survey Techniques of Water-Resource Investigations, book 3, chap. A7, 28 p.

Buchanan, T.J, and Somers, W.P., 1969, Discharge measurements at gaging stations: U.S. Geological Survey Techniques of Water-Resource Investigations, book 3, chap. A8, $65 \mathrm{p}$.

Carter, R.W., and Davidian, J., 1968, General procedure for gaging streams : U.S. Geological Survey Techniques of Water-Resource Investigations, book 3, chap. A6, 13 p.

Chow, V.T., 1959, Open-channel hydraulics: St. Louis, Mo., McGraw-Hill Publishing Company, 678 p.

Dieckmann, R.J., and Dyhouse, G.R., 1998, Changing history at St. Louis-Adjusting historic flows for frequency analysis: Las Vegas, Nevada, Proceedings of the First Federal Interagency Hydrologic Modeling Conference, 6 p.

Dyhouse, G.R., 1995, 1993 Midwest floods and water quality best management practices: Washington, D.C., National Research Council, Transportation Research Board, Record No. $1,483,7$ p.

Fenwick, G.B., 1969, Water-temperature effects on stage-discharge relations in large alluvial rivers: U.S. Army Corps of Engineers, Committee on Channel Stabilization, Technical Report No. 6, 41 p.

Goldman, D.M., Olsen, J.R., and Nanda, S.K., 2002, Comment on assessing flood hazard on dynamic rivers: Forum, American Geophysical Union Transactions, v. 83, no. 36, p. 396-398.
GreatRiverRoad, 2009, Visitors guide to Kaskaskia, Randolph County, Illinois: greatriverroad.com, http://www. greatriverroad.com/stegen/randattract/kaskaskia.htm, accessed August 17, 2009.

Grover, N.C., and Mansfield, G.R., 1938, Floods of Ohio and Mississippi Rivers, January-February 1937: U.S. Geological Survey Water-Supply Paper 838, 691 p.

Horowitz, A.J., 2006, The effect of the "Great Flood of 1993" on subsequent suspended sediment concentrations and fluxes in the Mississippi River Basin, USA: International Association of Hydrological Sciences, Proceedings of Sediment Dynamics and the Hydromorphology of Fluvial Systems, p. 110-119.

Huizinga, R.J., and Rydlund, P.H., Jr. 2001, Simulation of flow and evaluation of bridge scour at Horse Island Chute Bridge near Chester, Illinois: U.S. Geological Survey WaterResources Investigations Report 01-4176, 28 p.

Jarvis, C.S., and others, 1936, Floods in the United States: Magnitude and frequency: U.S. Geological Survey WaterSupply Paper 771, 497 p.

Jemberie, A.A., Pinter, N., and Remo, J.W.F., 2008, Hydrologic history of the Mississippi and Lower Missouri Rivers based on a refined specific-gage approach: Wiley Interscience Hydrological Processes, v. 10.1002, 12 p.

Johnson, G.P., Holmes, R.R., Jr., and Waite, L.A., 2004, The Great Flood of 1993 on the Upper Mississippi River-10 Years Later: U.S. Geological Survey Fact Sheet 2004-3024, $6 \mathrm{p}$.

Kesel, R.H., 2003, Human modifications to the sediment regime of the Lower Mississippi River flood plain: Geomorphology, v. 56, no. 3-4, p. 325-334.

Lagasse, P.F., Zevenbergen, L.W. Schall, J.D., and Clopper, P.E., 2001, Bridge scour and stream instability countermeasures: U.S. Federal Highway Administration Publication FHWA-NHI-01-003 Hydraulic Engineering Circular No. 23, $402 \mathrm{p}$.

Mississippi River Commission, 1925, Results of discharge observations, Mississippi River and its tributaries and outlets, 1838 - 1923: St. Louis, Missouri, Mississippi River Commission Print, 200.1-9-1925, 336 p.

Mueller, D.S., and Wagner, C.R., 2009, Measuring discharge with acoustic Doppler current profilers from a moving boat: U.S. Geological Survey Techniques and Methods 3A-22, $72 \mathrm{p}$.

Oberg, K.A., and Mueller, D.S., 2007, Validation of streamflow measurements made with acoustic Doppler current profilers: Journal of Hydraulic Engineering, v. 133.12, p. $1,421-1,432$. 
Pinter, N., Thomas, R., and Wlosinki, J.H., 2001, Assessing flood hazard on dynamic rivers: American Geophysical Union Transactions, v. 82, no. 31, p. 333, 338-339.

Pinter, N., and Heine, R.A., 2004, Hydrodynamic and morphodynamic response to river engineering documented by fixed-discharge analysis, Lower Missouri River, USA: Journal of Hydrology, v. 302, p. 70-91.

Rantz, S.E., and others, 1982, Measurement and computation of streamflow-Volume 1, Measurement of stage and discharge, and volume 2, Computation of discharge: U.S. Geological Survey Water-Supply Paper 2175, 631 p.

Sauer, V.B., and Meyer, R.W., 1992, Determination of error in individual discharge measurements: U.S. Geological Survey Open-File Report 92-144, 21 p.

Simon, Li and Associates, 1985, Seasonal effects of river stage-discharge relations at selected gages, Final Report: Fort Collins, Colorado, prepared for U.S. Army Corps of Engineers, Contract No. DACW43-85-D-0017, 96 p.

Shields, F.D., 1995, Fate of Lower Mississippi River habitats associated with river training dikes: Aquatic Conservation, Marine and Freshwater Ecosystems, v. 5, p. 97-108.

Smith, L.M., and Winkley, B.R., 1996, The response of the Lower Mississippi River to river engineering: Engineering Geology, v. 45, no. 1-4, p. 433-455.

Stevens, G.T., 1979, SLD Potamology Study (S-3): University of Missouri-Rolla, Institute of River Studies, Rolla, Missouri, 43 p. and Appendix.

U.S. Army Corps of Engineers, 2002, Hydrographic Surveying: U.S. Army Corps of Engineers, Manual No. 1110-21003,579 p.

Publishing support provided by:

Rolla and Denver Publishing Service Centers

For more information concerning this publication, contact:

Director

U.S. Geological Survey

Missouri Water Science Center

1400 Independence Road

Rolla, M0 65401

(573) 308-3667
U.S. Army Corps of Engineers, 2009a, Mississippi River at Cape Girardeau (MICG/0052A): U.S. Army Corps of Engineers, Mississippi River Basin Historic Data,

http://mvs-wc.mvs.usace.army.mil/archive/mi/micg micg_2008.pdf, accessed June 1, 2009.

U.S. Army Corps of Engineers, 2009b, Upper Mississippi River navigation charts: U.S. Army Corps of Engineers, Navigation Information Connection, http://www2.mvr. usace.army.mil/NIC2/mrcharts.cfm? index $=5$, accessed October 5, 2009.

U.S. Geological Survey, 2009a, 07010000 Mississippi River at St. Louis, MO: U.S. Geological Survey WaterData Report 2008, http://wdr.water.usgs.gov/wy20081 pdfs/07010000.2008.pdf, accessed June 1, 2009.

U.S. Geological Survey, 2009b, 07020500 Mississippi River at Chester, IL: U.S. Geological Survey WaterData Report 2008, http://wdr.water.usgs.gov/wy20081 pdfs/07020500.2008.pdf, accessed June 1, 2009.

U.S. Geological Survey, 2009c, 07022000 Mississippi River at Thebes, IL: U.S. Geological Survey WaterData Report 2008, http://wdr.water.usgs.gov/wy2008 pdfs/07022000.2008.pdf, accessed June 1, 2009.

U.S. Geological Survey, 2009d, Peak streamflow for Missouri, USGS 07010000 Mississippi River at St. Louis, MO: http://nwis.waterdata.usgs.gov/mo/nwis/peak? site no $=07010000 \&$ agency_cd $=U S G S \&$ format $=h t m l$, accessed July 24, 2009.

U.S. Geological Survey, 2009e, Peak streamflow for Missouri, USGS 07020500 Mississippi River at Chester, IL: http://nwis.waterdata.usgs.gov/mo/nwis/peak?site no $=07020500 \&$ agency $c d=U S G S \&$ format $=h t m l$, accessed July 24, 2009.

Wells, J.V.B., 1955, Compilation of records of surface waters of the United States through September 1950 Part 7, Lower Mississippi River Basin: U.S. Geological Survey WaterSupply Paper 1311, 606 p.

Or visit the Missouri Water Science Center Web site at: http://mo.water.usgs.gov/ 

6 Printed on recycled paper 